Portland State University

PDXScholar

$1-1-2010$

\title{
Activism and Identity: How Korea's Independence Movement Shaped the Korean Immigrant Experience in America, 1905-1945
}

Sara Elizabeth Deede

Portland State University

Follow this and additional works at: https://pdxscholar.library.pdx.edu/open_access_etds Let us know how access to this document benefits you.

\section{Recommended Citation}

Deede, Sara Elizabeth, "Activism and Identity: How Korea's Independence Movement Shaped the Korean Immigrant Experience in America, 1905-1945" (2010). Dissertations and Theses. Paper 174.

https://doi.org/10.15760/etd.174

This Thesis is brought to you for free and open access. It has been accepted for inclusion in Dissertations and Theses by an authorized administrator of PDXScholar. Please contact us if we can make this document more accessible: pdxscholar@pdx.edu. 
Activism and Identity: How Korea's Independence Movement

Shaped the Korean Immigrant Experience in America,

1905-1945

by

Sara Elizabeth Deede

A thesis submitted in partial fulfillment of the requirements for the degree of

Master of Arts

in

History

Thesis Committee

Katrine E. Barber, Chair

David A. Horowitz

Ken Ruoff

Michele R. Gamburd

Portland State University

(C)2010 


\begin{abstract}
The Korean Independence Movement was a four decades long endeavor from 1905 to 1945 by Koreans to liberate Korea from Japanese colonization. Korean immigrants in America played a vital role in the movement. They contributed money, organized patriotic activities in their communities to raise awareness and issued appeals for support to the U.S. government. Throughout the years, and from generation to generation, Korean immigrants remained loyal to Korea's cause for liberation. This study discusses how this intense patriotic involvement to their homeland affected Koreans immigrants' experiences in America, namely, how such intense overseas nationalism shaped their Americanization process.
\end{abstract}

Korean immigrants have told about their experiences in the form of memoirs, short narratives, interviews and speeches. These provide many first-person perspectives from which to understand Korean immigrants' changing senses of community, patriotism and acculturation. Many of these sources have come available in the last twenty years, but academic scholars have left these source largely untouched. Historians of Korean immigrant history often discuss the political components of the K.I.M. Although recognizing the importance of the Korean Independence Movement to Korean immigrants, scholars have, nonetheless, said very little as to how this movement affected them socially.

This study examines how America influenced historical developments culturally by shaping the attitudes of Korea's most politically active nationalists-the Korean immigrants in America. Furthermore, this study argues that Koreans in 
America utilized the K.I.M. for much more than Korean independence and that their motives evolved throughout the decades. The early immigrants used the K.I.M. as a means to establish a Korean community and establish social networks while the later activists, particularly after 1919, used their demonstrations to broadcast their distinct Asian identity as well as their assimilation and loyalty to America. More simply put, Korean patriotism and Korean immigrant "Americanization," are intimately connected. 


\section{Table of Contents}

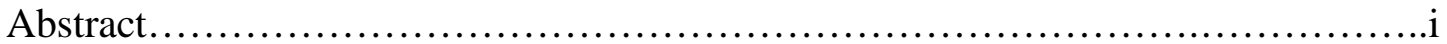

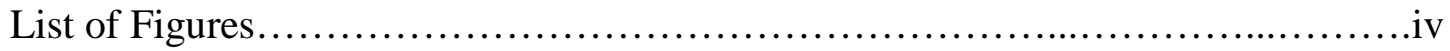

Introduction

Early Korean American History:...................................... 1

Chapter One

The Korean Push and American Pull of 1905:

Korean Immigrant Community in Early Twentieth Century America.........26

Chapter Two

The 1919 March First Movement:

Americanizatioin and Internationalization of Korean Immigrants..........66

Chapter Three

1945 and the Liberation of Korea:

From "Enemy Aliens" to Korean-American

Conclusion.......................................................... 124

Works Consulted........................................................... 131 


\section{List of Figures}

Figure 1

Protester Against Japan Trade..........................................74

Figure 2

Korean Independence Parade in Dinuba...............................77

Figure 3

Koreans Help Raise the Right Flag: Ad for the American-Korean

Victory Fund Drive Honolulu...................................... 116 


\section{Introduction \\ Early Korean American History}

If one could have asked Bong-Oh Lee why she was leaving her family in Korea to move to Hawaii and marry a man she had never met, she may have waxed romantic about raising a family, living comfortably on a farm and eventually sending her children to college. Perhaps the chance to escape the severe political and social tensions under Japanese colonial rule was too tempting to decline. As a Korean picture-bride who could not read or write, she may not have had the opportunity to speak to her motivation directly, but her son's memoir reveals his mother's youthful hope and desperation. What is certain is that in 1913, sixteen-year old Lee, along with two girlfriends, left their small village in Korea forever and set sail for Hawaii to meet their husbands-to-be for the first time. Bong-Oh Lee raised what would eventually be a family of ten children in a "typical plantation home next to the sugar mill." She and her husband could not always sufficiently feed and clothe their children. Eventually they left the sugar mill and opened a struggling tailoring business where the children were required to help. ${ }^{1}$

Lee's story of struggle is a familiar one among immigrants. For Koreans arriving in the United States and Hawaii in the early part of the twentieth century, stories of hardship were common, although they could also be optimistic. Abundant photos exist showing groups of newly arrived Korean girls, many of whom were picture brides who most certainly carried high hopes for their futures in America.

\footnotetext{
${ }^{1}$ Nam-Young Chung, "Always a Patriot” in Daisy Chun Rhoades, Passages to Paradise: Early Korean Immigrant Narratives from Hawaii (Academia Koreana Keimyung University Press, 1998), 34-36.
} 
One particularly interesting photo shows eleven young women, dressed in hanbok, the traditional Korean women's attire for festive events. They sit or stand on a bed of strewn grass against an unconvincing backdrop of a single tree; there is a chicken near the skirt of a woman in the front row. The unsmiling girls sit straight-backed, an assortment of expressions—hopeful, apprehensive, indignant. These Korean women, not unlike the hundreds of single Korean men who arrived in the United States and Hawaii a few years before them, embody the complicated story of racial tensions, identity conflicts, and cultural readjustments that encompassed their lives as an ethnic minority in a new land.

Despite its many trials, moving to America improved the lives for many Korean immigrants. During this time, poverty and violence gripped Korea where people bore the stress of living under severe political and economic exploitation. Therefore they looked to the United States and Hawaii to better themselves and their families. They also used their American setting to propel an independence movement against Japan during the first half of the twentieth century. Koreans in America were in a particularly advantageous position to sustain and bolster their independence movement. Many were better off financially and could send monetary contributions to Korean activists working in China and other places; they were safe from Japanese retaliation, and they were in closer contact with the political powers to which they were most trying to appeal. This movement, the Korean Independence Movement (K.I.M), became an integral part of the Korean immigrant experience in America until World War II. 
This study argues that the early immigrants used the Korean Independence Movement for much more than to secure independence for Korea. Korean expatriates used political activism as a way to establish Korean community and social networks in the United States and Hawaii. Later activists, particularly after 1919, used demonstrations to broadcast their unique Korean identity as well as their assimilation in and loyalty to America. In other words, Korean patriotism and Korean immigrant “Americanization" were intimately connected.

The Korean struggle for independence, although a twentieth century movement, carries with it the traces of centuries past. Korea's precarious geographical setting, as a peninsular country, contributed to its vulnerable position. Surrounded by three power-hungry countries—Russia, China and Japan—Korea served as a conduit for goods and ideas, as well as a place of politically strategic importance. In 1592 and 1597, Korea was the unlucky meeting point for wars between China and Japan. Twenty-five years later Koreans in the north part of the peninsula suffered from the devastating invasion of Manchu armies. Thereafter Korea attempted to seclude itself from foreign interaction, thus earning the nickname "Hermit Kingdom."

Korean powers could not keep the country isolated forever and by the midnineteenth century western ships increasingly drifted towards Korean shores. Koreans managed to drive these ships away. They were not so successful with their own neighbors, the Japanese, however. In 1875 Korea managed to fend off Japanese ships successfully, but the Japanese returned undeterred the following year, demanding recompense for the previous year's altercation. Korea acquiesced. 
The two countries drew up a treaty that effectively ended Korea's age of isolation. As a result, Korea opened up three ports to foreign trade including the southern port of Busan. The treaty allowed Japanese to set up shops, lend money, and control the import-export trade in Korea. Japan demanded that Korea declare itself independent from Chinese suzerainty, allowing the Japanese to set up a permanent mission on Korean soil without interference from the Chinese. In return, the Chinese pressured Korea to sign a treaty with the United States in 1882 . The KoreanAmerican Treaty ${ }^{2}$ insured a "lasting and sincere relationship between the two nations," and established amicable trade laws and therefore increased American presence in Korea, which the Chinese hoped would offset Japanese dominance of the peninsula. Thus began a long succession of treaty making with various foreign nations. $^{3}$

Despite China's efforts, Japanese presence in Korea grew in the late nineteenth century. The Chinese had reason to be hopeful when in 1894, Korean Emperor Kojong requested help from the Chinese army in order to quell a religious rebellion within Korea. Eager to regain influence, the Chinese government willingly sent troops. In response, the Japanese likewise sent troops to Korea without invitation. Conflict between Japanese and Chinese troops soon erupted, initiating the Sino-Japanese War. The Japanese successfully subdued the rebellion in Korea by massacring rebels while at the same time driving out Chinese forces.

\footnotetext{
${ }^{2}$ Also known as the "1882 Treaty of Amity and Commerce between the United States and Korea," and "Treaty of Chemulpo." Bong Youn Choy, Koreans in America (Chicago: Nelson-Hall, 1979), 43, 76.

${ }^{3}$ Sucheng Chan, introduction to Quiet Odyssey: A Pioneer Woman in America (Seattle, WA: University of Washington Press, 1990), xxiv.
} 
The defeat of the Chinese in 1895 led to the Treaty of Shimonoseki. Although official colonization would not occur for another decade, the Japanese used this victory to overtake Korea politically and culturally. Japanese forces overturned traditional class structures, implemented new laws, and introduced capitalism. In addition, they murdered Queen Min, the pro-Chinese wife of King Kojong, by setting her on fire. King Kojong, who suspected his own life was in danger, took sanctuary in Russia for over a year.

At this time, Russian influence in Asia was also increasing. In 1900, the Russian government, along with several western countries, sent forces to China to help crush the Boxer Rebellion. After troops defeated the rebels, many Russians stayed in Asia, particularly in northern Korea. The Japanese demanded they withdraw but when the Russians refused, yet another war took place on Korean soil. Because of its weak military and perhaps in an attempt to avoid further retributions from Japan, Korea declared neutrality. The Russo-Japanese War lasted from February 1904 to July 1905, ending with another Japanese victory. In the Treaty of Portsmouth, Russia relinquished influence in Manchuria and Northern Korea, strengthening Japanese authority.

The same year in 1905, Japan officially declared Korea its protectorate. Kojong kept his position on the throne and Korea remained technically independent. But the Korean government had little political authority and Japanese institutions and laws continued to infiltrate Korean systems. ${ }^{4}$ Japanese colonization of Korea in the early twentieth century commenced a long period of suffering and political turmoil

\footnotetext{
${ }^{4}$ Chan, Quiet Odyssey, xxiii-xxix.
} 
for the Korean people. Yet Korea's problems began with the first treaty with Japan in 1875. Although the stated purpose of the Korean Independence Movement was political freedom from Japan, the movement's political fervor was laden with decades' worth of grievances.

Japanese domination continued to expand after 1905. In 1907, King Kojong abdicated his throne and by 1910, after five years of unofficial subjugation, Japanese authorities declared Korea an official colony. According to the 1910 Treaty of Annexation between Japan and Korea, colonization was necessary in "order to maintain peace and stability in Korea, to promote the prosperity and welfare of Koreans..." ${ }^{5}$ Under this new leadership, Korea underwent dramatic transformations. New policies forbade public gatherings, closed down newspapers, and required Koreans to speak Japanese in schools and all other government spaces. Anyone found breaking these regulations met severe physical punishment or incarceration.

Covert resistance occurred within Korea but at great risk. In her memoir, Kyung Soo Cha, a Korean woman who participated in the Independence Movement in Korea and the United States, described asking her mother the meaning of “independence." "My mother replied, 'The Japanese came to our country to exploit and rule us. Independence means that we want to live by ourselves. Don't let anyone hear you saying the word. The Japanese will catch you and beat you.",6 Kyung's experiences were not exceptional. Japanese officials commonly whipped Koreans or even killed them for openly supporting independence.

\footnotetext{
5 “1910 Treaty of Annexation: Annexation of Korea by Japan,” August 22, 1910.

${ }^{6}$ Kyung Soo Cha, Pumpkin Flower and Patriotism, trans. Hyun H. Kim (Los Angeles, CA., Korean American Educational Research Center, 1991), 27.
} 
Although Japanese officials in Korea tried to stifle resistance, Korean nationalist organizations persisted and efforts to resist colonization stretched out over the four decades of Japanese rule. Anti-colonial activists employed many forms of resistance, from covert communications to public demonstrations in Korea and internationally. Koreans eventually gained independence, but not until the defeat of the Japanese in the Second World War.

The Korean Independence Movement was an international movement with ties to many foreign countries including America, China and Russia, each with opinions on how to best handle Korea's movement for independence. This toss into the international political web was a significant transition for a country that had only just emerged from its hermit life.

Apart from Japan, America was the most significant foreign influence shaping Korean culture and politics in the early twentieth century. America's role within Korean history is an important but complicated one. Americans first entered Korea in the late nineteenth century. They established schools and hospitals, coloring Korean social and political thought with Western hues. However, these were not American politicians shaping events, but rather American missionaries.

Methodist and Presbyterian missionaries from America were the first religious sects to establish an enduring and relatively amicable relationship with the Korean people. American Protestants who entered Korea in the mid 1880s coexisted well with the Koreans. Americans were not the first to introduce Christianity (Chinese and French missionaries had attempted but failed to found Christian missions); yet they 
were the most successful in attracting converts. And unlike in China and Japan, Christianity found a stronghold in Korea.

The success of American missionaries stemmed in part from their refraining to engage in open proselytizing, a practice that Korean policy forbade in the late nineteenth century. Therefore, they did not overtly challenge Korean policy. Instead, they entered Korea as doctors, nurses and teachers. Another key factor was the good relationships American missionaries fostered with King Kojong and Queen Min. After Horace N. Allen, one of the first American Protestant missionaries, saved the life of the Queen's cousin, he and his wife became favored guests of the royal family. The King eventually turned to the American missionaries for political advice. As Kojong sought to become more independent from Chinese and Japanese influence, he appealed to the U.S. State Department for American advisors. His requests were denied, so he turned to the American missionaries instead, thus building strong and trusted relationships with them. ${ }^{7}$

Koreans found Christianity appealing because it eased strict social roles and reinforced their patriotic aims. Christianity expanded the roles of Korean women when Christian missionaries encouraged them to participate in church. Strict social confines in the nineteenth century Korea meant that most Korean women remained close to home and never received an education like their male counterparts. Christian ethics, as taught by missionaries, encouraged them to study, participate in church activities and travel to spread their biblical knowledge. Christian missionary schools

\footnotetext{
${ }^{7}$ Wayne Patterson, The Korean Frontier in America: Immigration to Hawaii 1896-1910 (University of Hawaii Press, 1988), 20.
} 
also introduced ideas of democracy that most likely strengthened anti-Japanese sentiment. These two aspects of Christian missionary work were popular considering Korea's cultural and political climate at that time. ${ }^{8}$ By introducing modern concepts of liberty and equality, American missionaries and their early converts laid the groundwork for a multifaceted relationship between America and Korea as well as Korea's four decade long struggle for independence.

American politicians in the early twentieth century had an unofficial hands-off policy regarding Korea. Political non-interaction, in its own way, shaped Korean historical events. After the 1905 Russo-Japanese war, for example, U.S. Secretary of War, William Howard Taft made an agreement with Japanese Prime Minister, Katsura Taro, to respect Japan's claim to Korea if Japan would not impede America's interests in the Philippines. By turning away from Korean interests in the late nineteenth century and for nearly half a century thereafter, America left Korea open to unfriendly influences.

As the Korean Independence Movement began to take form in Korea and abroad, the American government continued its pattern of non-interference. Nonetheless, America influenced Korean historical developments culturally, as this thesis will further explore, by shaping the attitudes of Korea's most politically active nationalists - the Korean immigrants in America.

Living abroad, whether in China or America, was advantageous for Korean activists because it freed them from the dangers of protesting within a Japanesecolonized Korea and it gave them closer access to higher-power governments. Many

\footnotetext{
${ }^{8}$ Chan, Quiet Odyssey, xxxv-xxxviii
} 
Koreans hoped that overseas protests would spark international attention to the plight of Korea. Their actions are historically important because they reflect the national and social complexities of global relations before World War II. They also reflect the diplomatic leverage of transnational communities and the precarious nature of immigrant experiences in the modern world.

Korean immigrants in the United States and Hawaii played a pivotal role in the Korean Independence Movement, but Korean immigration to America was rarely political. Horace N. Allen, an American, Christian missionary turned American diplomatic minister, was most influential in setting up an immigration system from Korea to America. On a return trip from America to Korea he stopped in Hawaii to meet with the Hawaiian Sugar Planters Association which was interested in a Korean workforce. Chinese immigration had diminished after the passage of the Chinese Exclusion Act in 1882, and some sugar plantation owners were concerned about a Japanese monopoly of labor, which might lead to labor strikes. Allen persuaded King Kojong to set up an emigration bureau, and the recruitment of Korean laborer went quickly underway. ${ }^{9}$

Compared to other Asian immigrant populations, far fewer Koreans immigrated to the United States. They arrived long after other nationalities, like the Japanese and Chinese, who had already settled in the United States and Hawaii. The earliest Korean immigrants arrived in the late 1890s and early 1900s. They were very few in number and poorly documented. By 1902, only sixteen documented Koreans lived in the Territory of Hawaii. From 1903 to 1905, just over 7,000 Koreans moved

\footnotetext{
${ }^{9}$ Patterson, The Korean Frontier, 19-23.
} 
to Hawaii to work on sugar plantations. Only 637 of these immigrants were women, and 541 were children. Of these 7,000 Koreans about 2,000 eventually relocated to the continental United States, mainly to work on farms in California. ${ }^{10}$ In addition to field workers, a small number of refugees and students immigrated to the United States during this period. In 1905, Japanese officials limited Korean immigration to America to prevent them from breaking Japanese labor strikes and sabotaging Japanese efforts for earning a better wage. ${ }^{11}$ Immigration to America remained difficult for Koreans until after World War II.

Their numbers were small, yet they would be most influential in organizing and leading the Korean Independence Movement in America. Historian Wayne Patterson argues that by annexing Korea and robbing its citizens of their independence and identity, the Japanese essentially invited a massive resistance movement. What they encountered was a tenacious resistance at home and a fierce nationalist endeavor abroad that Patterson claims is unmatched by any other overseas nationalist movement. $^{12}$

For the Korean immigrants who arrived in America before World War II, this significant political and cultural movement dramatically shaped their patriotic notions and assimilation processes, a fact that is supported by the many first-hand accounts attesting to the immigrants' overwhelming dedication to Korea's independence. The K.I.M was undoubtedly a major component to the founding of Korean immigrant

\footnotetext{
${ }^{10}$ Walter Nugent, Into the West (New York: Vintage Books, 2001), 216.

${ }^{11}$ Patterson, The Korean Frontier, 135.

${ }^{12}$ Wayne Patterson, The Ilse: First Generation Korea Immigrants in Hawai'i 1903-1973 (Honolulu; University of Hawaii Press, 2000), 100-119.
} 
communities in America. More significant, however, are the broad social implications of such a long-lasting patriotic movement.

The continual fostering of Korean patriotic sentiment during the establishment of early Korean immigrant communities was not without consequence. The K.I.M. was so predominant an aspect of immigrant life that founding a Korean-American community and struggling for Korea's independence developed hand-in-hand, despite being seemingly contradictory impulses. From within this historical context arise a number of questions. Did participation in the movement foster patriotic feelings toward America as well as toward Korea? To what degree were Korean immigrants successful in differentiating themselves from other Asian groups? How did emigration and Korean activism change Korean social roles, particularly women's roles? How did the K.I.M. in America change over time and, how did the movement serve to shape Korean notions of identity and Americanization?

A thorough review of the literature will show that scholars of Korean history as well as early Korean immigrants had much to say about the K.I.M. What scholars have not thoroughly discussed is how the K.I.M. influenced the Korean immigrants socially or how it related to their Americanization processes. Therefore, I have studied a number of first-hand accounts in order to explore just how immigrant nationalism directed toward their country of origin affected their course of acculturation. 
To frame my historical questions and research, I relied heavily on Benedict Anderson's, Imagined Communities. ${ }^{13}$ Anderson's work offers compelling explanation as to how and why communities form under nationalistic constructions. I referred often to Erez Manela's The Wilsonian Moment, which examines the Korean Independence Movement and other nationalist movements in the same time period, linking their causes to global political and social themes. ${ }^{14}$ These treatments help bring broader significance to my finely focused study, as well as providing insight into the motivations that spur nationalist, integration and community-creating endeavors.

Korean scholar Oh In-Cheol claims that Korean historians rarely look outside Asia when studying the Independence movement. ${ }^{15}$ Conversely, the many accounts by Korean American immigrants and their children quickly reveal that their lives were engrossed with the happenings in Korea. Their communities in America, though small, warrant consideration within Korean history as well as within Asian American history. American scholars who write on Koreans in America and Hawaii during the first half of the twentieth century are not apt to neglect the patriotic activities of the first generations of Koreans. Historians, such as Erez Manela and Timothy L. Savage, have provided detailed treatments of the political importance of the Korea Independence Movement as well as the fervent sincerity of Korean patriots.

\footnotetext{
${ }^{13}$ Benedict Anderson, Imagined Communities: Reflections of the Origins and Spread of Nationalism (New York: Verso, 2006).

${ }^{14}$ Erez Manela, The Wilsonian Moment: Self-Determination and the International Origins of Anticolonial Nationalism (University of Oxford Press, 2007).

${ }^{15} \mathrm{Oh}$ In-Cheol, Study on Korean Immigration and Independence Movements in Hawaii-Relating to Korean Churches and Picture Bride-1903-2003. (Cholla Namdo, South Korea: Sung Moon, 2005), first page of unnumbered preface.
} 
Even so, scholars of Korean history rarely explore the social implications of the nationalist movement. There is little literature that examines how political activism fostered a new Korean American consciousness.

Research focusing particularly on Korean communities in America prior to World War II is a narrow field. Additionally, it is a topic studied predominantly by Korean Americans. Whereas historians of both Asian and non-Asian background examine Chinese and Japanese immigrant histories, Korean immigrant history remains an insular field, an attempt by Korean Americans to preserve their heritage. This, however, does not diminish the value of their scholarship, for there are several scholars whose research has contributed valuable insights. A consideration of their work is imperative to any serious treatment on the topic of early Korean immigrants.

Chong-sik Lee provides a sweeping history of the Korean Independence Movement in The Politics of Korean Nationalism. ${ }^{16}$ Lee concentrates mainly on political events in Korea and China but provided a few informative pages on patriotic activities in the United States and Hawaii. His book remains the most comprehensive academic study on the Korean Independence Movement in English. Bong-youn Choy offers a grand overview of Korean immigrant life in Koreans in America. ${ }^{17}$ Although the Korean Independence Movement is not the focus, Choy's treatment nonetheless provides the most thorough details on the topic. One of the most useful and prolific writers on Korean immigrant topics is historian Wayne Patterson, who is, almost without exception, the only scholar of Korean immigrant history of non-Korean

\footnotetext{
${ }^{16}$ Chong-sik Lee, The Politics of Korean Nationalism (Berkley: University of California Press, 1963).

${ }^{17}$ Bong-youn Choy, Koreans in America (Chicago: Nelson-Hall, 1979).
} 
heritage. Patterson's The Korean Frontier in America: Immigration to Hawaii 18961910 and The Ilse: First Generation Korean Immigrants in Hawai'i 1903-1973 concentrate on immigrant experiences in Hawaii and were valuable references for this study.

Sucheng Chan is a major contributor to the field of Asian Studies and is also the editor of the memoir Quiet Odyssey: A Pioneer Korean Woman in America. ${ }^{18}$ Most of this book is a primary account by Korean immigrant Mary Paik Lee recounting her experiences in America. However, Chan provides a grand tour of Korean history in the book's introduction. Her contribution summarizes Korean history from the sixteenth century and then provides more details into the nineteenth and twentieth centuries. I continuously reference Chan's introductory essay for its thorough yet concise treatment of Korean history.

There are also a few key researchers of Korean immigrant history whose works are fundamental for my own. They compiled useful first-person accounts of early Korean immigrants into single volumes. Harold Hakwon Sunoo and Sonia Shinn Sunoo conducted and published several important interviews in Oral History of Early Korean Immigrants in the United States: 1903-1907: 23 Selected Interviews from the Korean Oral History Project of Early Korean Immigrants. ${ }^{19}$ They conducted these interviews in the 1980s when most of the interviewees were well into their eighties and nineties. The authors' purpose was not so much to draw

\footnotetext{
${ }^{18}$ Mary Paik Lee, Quiet Odyssey: A Pioneer Korean Woman in America, ed. Sucheng Chan (Seattle: University of Washington Press, 1990).

${ }^{19}$ Harold Hakwon Sunoo and Sonia Shinn Sunoo, Korean Kaleidoscope: Oral Histories, Volume One, Early Korean Pioneers in USA: 1903-1905, transcript, Korean Oral History Project Series 1, Sierra Mission Area, United Presbyterian Church, USA (1982).
} 
conclusions or to develop theories from these accounts but rather to record early immigrant narratives while still possible to do so.

\section{Daisy Chun Rhode's Passages to Paradise: Early Korean Immigrant}

Narratives from Hawaii provides one of the most useful collections of first-person accounts for my study. ${ }^{20}$ The compilation is comprised of thirty-three narratives from the children of early Korean immigrants. The accounts are diverse and yet one can draw out certain themes concerning political passion, racism, and changing social structures within Korean communities in Hawaii and America. These accounts were particularly informative because the authors often relayed the experiences of their parents as well as their own. They talked about how their parents reacted to the Korean Independence Movement, what perceptions they had of white people and other Asian groups, and how they felt about their children's changing behaviors and perceptions, demonstrating cultural and political shifts. As a result, this collection provides an invaluable source for generational comparison.

In addition to the compilation of first-person accounts by Daisy Chun Rhodes, Harold Hakwon Sunoo and Sonia Shinn Sunoo, several stand-alone memoirs offer depictions of daily life as a Korean immigrant. For this study, I reference one memoir in particular that fits well into the period I examine. Mary Paik Lee's Quiet Odyssey: A Pioneer Korean Woman in America colorfully documents the early Korean experience, providing useful details of daily life and including historical observation. The memoirs of Lee and others were useful in providing factual context

\footnotetext{
${ }^{20}$ Daisy Chun Rhodes, Passages to Paradise: Early Korean Immigrant Narratives from Hawai'i. (Los Angeles: Koreana Keimyung University Press, 1998).
} 
as well as a personal understanding of their experiences as a minority within first half of the twentieth century.

Memoirs and interviews offer interpretations of the past by people who experienced them first hand. However, I also examined speeches, letters, books, articles and photographs by early Korean immigrants that illustrate Korean immigrant patriotism and the building of identity in the first decades of the twentieth century. ${ }^{21}$ The patriotic speeches allow one to know exactly what rhetoric and methods Korean activists utilized to rally support, whether from Korean immigrants or from a wider American public. The photographs I examined offer a glimpse of how Korean immigrants presented their independence movement to a general American public. Because very few first-person accounts offer specific descriptions of patriotic events, I used photos to provide a few more elements to interpret.

For this study I chose to focus on the written and spoken words of Korean immigrants because I felt that they were the most effective sources for understanding changing perceptions of Korean immigrant identity. I found that first-person accounts of early Korean immigrant life in America reveal much in this regard, for political movements, like the Korean Independence Movement, are hardly confined to political realms, but are instead entwined with social and cultural evolutions. They are deeply personal mass movements that have significant reverberations on a population's psyche.

\footnotetext{
${ }^{21}$ Although I received a few helpful sources from Korean American historical societies, the East Asian Digital archive on the University of Southern California website provides the most inclusive and easily accessible collection of Korean American historical documents. See:http://digarc.usc.edu.
} 
I also chose to work with memoirs and first-person narratives because, unlike letters and diaries, they are accessible and available in English. In recent decades some Asian historical societies have published first-person accounts as a means of preserving history. Although there may not be a large of body of scholarly research focusing on early Korean immigrants, enough first-person material exists to construct a thoughtful discussion on their lives and to consider how their personal story interweaves with the grand genre of American history.

For this project I read a large number of first-person accounts as a means for historical research in order to uncover a broader understanding of a population's mindset. In some ways, memoirs make the historians work easier. First-person accounts provide a face to historical events. Newspapers, photographs and statistics provide valuable information and multiple means through which to attain an understanding of history. But, first-person narratives reveal stories that can rarely be found anywhere else. Often memoirs depict history in a way that is both humanizing and informative. For example, Korean immigrant Mary Paik Lee offered this insightful recollection:

We landed in San Francisco on December 3, 1906. As we walked down the gangplank, a group of young white men were standing around, waiting to see what kind of creatures were disembarking. We must have been a very queerlooking group. They laughed at us and spat in our faces; one man kicked up Mother's skirt and called us names we couldn't understand. Of course, their actions and attitudes left no doubt about their feelings toward us. I was so upset. I asked Father why we had come to a place where we were not wanted. He replied that we deserved what we got because that was the same kind of treatment that Koreans had given to the first American missionaries in Korea; the children had thrown rocks at them, calling them "white devils" because of their blue eyes and yellow or red hair. He explained that anything new and the missionaries just lowered their heads and paid no attention to their strange causes some fear at first, so ridicule and violence often result. He said 
tormentors. They showed by their actions and good works that they were just as good or even better than those who laughed at them. He said that is exactly what we must try to do here in America-study hard and learn to show Americans that we are just as good as they are. ${ }^{22}$

This passage is short, but conveys much. It relays historical information regarding American missionary influences in Korea and severe discrimination in early twentieth century California. But it also relays how Lee made sense of her experience, expressing fear of starting a new life in a foreign country.

First-person accounts, like all historical data, have their limitations. Despite their informative and personal nature, memoirs can be tricky to use as historical documents. They can allow one to observe history directly and intensely, to capture thoughts, moods and incidences. Yet their use also requires caution. In Recording Oral History, Valerie Yow warns (or perhaps entices) researchers that interpretations of past events may shift with time. The significance of some events expands while others recede based on the narrator's perception of what is important at the time of narration. $^{23}$ In other words, a recollection speaks about a person's present as well as his or her past.

The memoirs and interviews I used for this study came from diverse sources. Some, like Quiet Odyssey, are heavily edited, placed within historical context and

\footnotetext{
${ }^{22}$ Mary Paik Lee, 12-13.

${ }^{23}$ Valerie Raleigh Yow. Recording Oral History: A Practical Guide for Social Scientists (Thousand Oaks: Sage Publications, 1994), 20-25. Yet research has helped easy the worried minds of historians who shy away from using human memory as reliable evidence. In one experiment, for example, researchers asked participants to recall specific events from the past. Nine months later they were again asked to recall the same events this time with a different interviewer. According to the study, 91 percent of participants provided answers consistent with previous results. Furthermore, although how people judged past experiences varied (for example, immigration was hard; immigration was liberating, etc.) their memories were usually in agreement concerning factual statements (for example, immigrants worked six days a week).
} 
geared towards a large audience. Heavy editing means that the narrative is shaped by the editor in order to be published. Other accounts stem from oral history projects and Korean education centers and have been minimally edited. Like all first-person accounts, one must examine the memoirs, narratives and interviews of early Korean immigrants critically. Read individually, the accounts are merely anecdotal and one must never assume that a single person represents a whole group.

The challenges associated with analyzing first-person accounts are also indicative of their strengths as historical records. A person's memory is not a guaranteed source of historical facts and data. Certainly, some narratives may be filled with errors and untruths. Yet, with the direction and guidance from interviewers and responsible editors, the reading audience can trust that at least published accounts are legitimate historical sources. ${ }^{24}$ Having not done any interviews myself, I relied on the published work of other interviewers and editors. This may seem like it makes my task easier, and in some ways it does, but it also brings in another layer of complexity, for in this situation one must consider not just the subject but also the person directing the project. Yow explains that oral history discusses the past but also reflects "current circumstances and needs." ${ }^{25}$ Therefore, when reading memoirs, narratives and interviews, I considered what the Korean immigrants chose to discuss and why, as well as whether the editor or interviewer

\footnotetext{
${ }^{24}$ Sucheng Chan, for example, provides a lengthy appendix to Mary Paik Lee's memoir. Chan contributes historical context to some of Lee's stories and points out where there are idiosyncrasies in Lee's account. Sucheng Chan writes, "My share in this scholarly edition has been to augment Mrs. Lee's text with a comprehensive explication, to verify her factual statements, and to edit for increased readability her lively, perceptive prose." Quiet Odyssey, 135.

${ }^{25}$ Valerie Raleigh Yow, Recording Oral History: A Practical Guide for Social Scientist (Thousand Oaks: Sage Publications, 1994), 25.
} 
was guiding the narrative, and if so, how. Because the majority of interviewers and editors of first-person compilations and memoirs are themselves Korean American, there is a double agenda in the making. If we accept that past recollections reflect current needs, one might conclude that there is a joint desire between the younger and the older Korean American generations to draw up their own history and to intimately connect it with the history of their homeland.

This project examined first-person accounts based on the periods and places on which they focused. This task was not so easy. Many insightful memoirs focusing on Korean American identity post-World War II exist. Likewise, many interesting first-person accounts depict life in colonized Korea. Unfortunately for this project their usefulness was limited. After collecting suitable accounts I identified the key themes within each text. Thereafter I immersed myself in the literature, reading and rereading accounts and taking extensive notes until I recognized common reoccurring themes among the narratives. I chose which themes I felt best illuminated the early Korean immigrant experience, such as Korean patriotism, antiJapanese sentiment, and relations with white Americans, acculturation, gender role changes and generational differences. These key issues are the imperative aspects of the early Korean American experience. The research I conducted for this study was not exhaustive. Certainly more interviews and first person accounts are waiting to be discovered. ${ }^{26}$

\footnotetext{
${ }^{26}$ The East Asian Library at University of Southern California, for example, recently made available an audio collection of Korean immigrant interviews, available online. I did not consult these sources for my study.
} 
Of the dozens of accounts I have examined, I have chosen key figures who represent the collective and who depict the changes within the Korean immigrant community throughout the first four decades of the twentieth century. In Chapter One, I reference the life of Sook-Chin Ahn, one of the few Korean women who arrived in Hawaii during the first year of immigration open to Koreans. In Chapter Two, the year of the March First Uprising, I use the written and spoken words of prominent K.I.M leaders, particularly of Phillip Jaisohn, a western-educated immigrant. The focus of Chapter Three is Mary Paik Lee, a farmer's wife in California, whose memoir expresses the process of acculturation throughout the years. Within these chapters, I use a number of first-person accounts that support and supplement these narratives. Together, their stories provide a sweeping and yet complex picture of early Korean immigrant history in America.

The following chapters are organized based on three specific periods, 19031905, 1919-1921 and 1941-1945. These periods mark significant years of Korean political activism in Korean and World history_Japanese colonization of Korea, the closing of World War I and the Paris Peace Conference, and Japan's defeat in World War II. The chapters do not adhere strictly to these periods, instead they provide a cohesive historical account spanning the decades of the Korean Independence Movement; however, these dates serve as useful guideposts for understanding the K.I.M. in America.

These dates are internationally relevant, but they are also key periods in Korean American history as well. The year 1905 marked the closing of the first wave of Korean immigrants to America ensuring that no large population of Koreans would 
enter America again until the 1950s. The March Uprising in Korea in 1919 created a surge of Korean nationalist activities in the United States and is the most memorialized event throughout the Korean Independence Movement. When the Japanese were defeated in World War II in 1945, Korea gained its freedom and the Korean Independence Movement came to a close. These are not the only significant years within the forty years of the Korean Independence Movement. Yet they represent major events and serve as a comparison for change over time within the Korean immigrant community in the United States and Hawaii.

The Korean Independence Movement and Korean immigrant nationalism in America provides much on which to contemplate. Korean immigrant nationalism provides an excellent case study of social, racial, or political issues. In this thesis I do not cover all themes connected to this topic. Despite the political themes central to this study, I will not be concentrating on in-depth political relations among Japan, Korea and America. Nor will I focus on the social differences and assimilation patterns between Korean immigrants in Hawaii and those who settled in America, of which there are plenty. These are not unimportant topics; they are simply out of scope for this study. Instead I will focus mainly on how nationalist activities effected Korean assimilation and Americanization processes, how Korean identity was formed through and by the K.I.M., and how Korean immigrant roles, particularly women's roles, changed over time.

Chapter One concentrates on the period from 1903 to 1905, the first and last wave of Korean immigration to Hawaii and the American mainland before World War II. Relocating to a foreign country forced Koreans to reconfigure their lives. 
Traditional ways of living, thinking and interacting were adapted to fit foreign surroundings. This chapter discusses how the Korean Independence Movement shaped the early Korean immigrant experience at the same time they were adjusting to their new American life.

Chapter Two revolves around the year 1919, the year of the March First Uprising throughout Korea. It is also the year of the Paris Peace Conference which aspired to reconstruct war-torn Europe and served as an inspiration for colonized countries around the world, including Korea. Even Koreans in America, most of whom had lived in America for years and reached some degree of assimilation, felt a great surge in Korean nationalism. The period from 1919 to 1921 saw a rise in Korean activism in the United States and Hawaii, but activism that Koreans consciously blended with a display of loyalty towards America. This chapter, therefore, discusses their dual senses of nationalism and how this affected their assimilation and Americanization processes.

Chapter Three, which focuses on the years 1941-1945, discusses similar themes as in Chapter Two in conjunction with World War II and the closing of the Korean Independence Movement. By this time, many Korean families had second or third generation Korean American members. They no longer considered Korea their homeland the way the earliest immigrants had. However, they still felt strongly patriotic and emotionally involved with Korea's independence movement. This last chapter discusses the pre-World War II lull in Korean patriotic activities, the resurgence of patriotism with America's entry into war and how these activities reflected the change in the Korean immigrant community over time. 
By analyzing Korean activism in America one can better understand how political and diplomatic agendas reflect and form social experiences. In the case of Korean immigrants, a sense of community developed from larger circumstances other than cultural similarities. Korean activism generated a wide range of benefits, including emotional support, Korean services, legal and cultural recognition, and perhaps diversion from immigrant hardships. The Korean experience in America illustrates how nationalism forms and operates differently in foreign countries than it does in homelands. This is true for identity as well. Living as a foreigner compels one to examine his or her ethnic and national identities in new contexts. This case study demonstrates how emigration compels some immigrants to consciously assert and perform their unique cultural identity while, at the same time, struggling to gain acceptance from the host country. I have used first-person accounts to understand how Koreans constructed their identity, a method which merges historical and personal accounts and allows Korean immigrants a voice in American and Korean American history. 
"The meaning of immigration is suffering." Rhee Pyong-uk ${ }^{27}$

\section{CHAPTER ONE}

\section{The Korean Push and American Pull Of 1905: \\ Korean Immigrant Community in Early Twentieth Century America}

Immigration to America restructured established Korean social traditions by

mixing people who came from different regions throughout Korea, had different

socio-economic backgrounds, and who spoke different dialects of Korean. In Hawaii

and America, Korean farmers from southern Korea worked and lived next to educated

city dwellers from the North, a rare occurrence in Korea. ${ }^{28}$ This was a significant

adjustment for those having come from a culture that placed great importance on

family roles, ancestry, and social traditions. Koreans who left their homes for

America parted from their intricate kinship networks, one of the most fundamental

aspects of their lives. They rebuilt a sense of kinship, not on ancient customs, but

rather on new political and religious foundations.

In the earliest years of Korean settlement in America, immigrants focused on

the Korean Independence Movement as a way to build a sense of community in a

strange new land. The K.I.M. allowed immigrants a way to stay connected to their

homeland by participating in one of the most important political struggles for

${ }^{27}$ Rhee Pyong-uk, interview by Sonia Shinn Sunoo (5 January, 1976) Korean Kaleidoscope: Oral Histories, Volume One, Early Korean Pioneers in USA: 1903-1905, transcript, Korean Oral History Project Series 1, Sierra Mission Area, United Presbyterian Church, USA (1982). 3.

${ }^{28}$ Wayne Patterson, The Korean Frontier in America: Immigration to Hawaii 1896-1910 (University of Hawaii Press, 1988), 103-104. This does not mean, however, that the urban and rural populations immigrated in even numbers. In fact, Patterson refers to a source that claims only one in seven Korean immigrants were farmers in Korea. This could also be attributed to the fact that severe economic depression forced many Korean farmers to the cities in the late nineteenth century. Therefore, this statistic is vague concerning Korean backgrounds. In any case, immigrants arrived from cities throughout Korea contributing to an unusually diverse Korean population. 
contemporary Korea, independence from Japan. At the same time, the K.I.M provided immigrants with a path toward assimilation into American culture. This is especially apparent when examining the changing political and social roles of Korean immigrant women.

The year 1905 was the closing of the first, albeit brief, wave of Korean immigration to America and Hawaii. More than 7,000 Korean immigrants moved to America before World War II, yet the majority of them arrived between 1903 and 1905. ${ }^{29}$ Less than 10 percent of these immigrants were women. Like the men, these women adapted to a foreign country and culture. A significant expansion of their social and public roles meant, for women, the changes associated with immigration were more profound than for their male counterparts.

Koreans had many motives for emigrating in the early 1900s, the first among them financial. They hoped to accumulate money to send back to their families and to establish better lives for themselves whether in Korea or America. Although a small number were students or railroad workers, the majority of the initial immigrants started out as plantation laborers. Considering the widespread poverty of Korea, most Koreans moving to Hawaii felt that immigration was their best option. American recruiters in Korea told of easy wealth, a myth poor Koreans were all too eager to believe. $^{30}$ If they had hoped for an idyllic Hawaii—volcanic mountains draped in

\footnotetext{
${ }^{29}$ Some statistics will serve to highlight the stark minority status Koreans faced at the turn of the century. When the first Koreans arrived in 1903, more than 80,000 Japanese already lived in the United States and Hawaii, and more than 86,000 Chinese. More than one million foreign-born immigrants resided in the United States and Hawaii overall. Elliot Robert Barkan, From All Points: America's Immigrant West, 1870's-1952 (Indianapolis: Indiana University Press, 2007), 463.

${ }^{30}$ Sucheng Chan, introduction to Quiet Odyssey: A Pioneer Woman in America (Seattle: University of Washington Press, 1990), xli.
} 
lush green, pleasant weather all year round, ailment-curing air, charming plantations where work was no more strenuous than a "nap under a pear tree" and "gold dollars were blossoming on every bush"- - they were at least right about the scenery. ${ }^{31}$

The influx of Korean immigrants to Hawaii was due, in no small part, to America's love for sugar. By 1835, sugar was the main crop of Hawaii and by 1850 the diplomatic machinery was in place to promote the immigration of foreigners to work on sugar plantations. In 1876, a treaty between the United States and the Kingdom of Hawaii (Hawaii was not annexed until 1898) allowed for duty free export of sugar to American markets, thus greatly increasing the profit for Hawaii's sugar producers. Thereafter sugar production increased tenfold and so began the large influx of Chinese laborers and the development of an industry that depended on cheap, foreign labor. ${ }^{32}$ Between 1850 and 1920, more than 300,000 Asians entered Hawaii for work, transforming Hawaii’s ethnic and economic landscape. According to an 1853 survey, 97 percent of the population of the Hawaiian Islands was ethnically Hawaiian, 2 percent Caucasian, and just 0.5 percent Chinese. Seventy years later, 62 percent of the population of Hawaii was Asian, 42 percent of whom were Japanese. Koreans made up just less than 2 percent. Native Hawaiians had dwindled to a mere 16.3 percent. $^{33}$

\footnotetext{
${ }^{31}$ Wayne Patterson, The Korean Frontier in America: Immigration to Hawaii 1896-1910 (Honolulu: University of Hawaii Press, 1988), 52, 93.

${ }^{32}$ Patterson, The Korean Frontier, 3.

${ }^{33}$ Ronald Takaki, Strangers From a Different Shore: A History of Asian Americans (New York, Penguin Books, 1989), 132.
} 
Most immigrants in Hawaii described plantation work as grueling and in many ways degrading. At five a.m. every morning screaming sirens would awaken the laborers. The yells by the company policemen who stormed through the camps shouting "Get up! Get up!" soon followed. Once the workers left their homes, the foremen organized them into gangs of twenty or thirty before marching or trucking them to their fields. The foremen constantly oversaw the laborers throughout the day to make sure they worked efficiently. Many immigrants recalled being afraid, claiming the foremen would ride around on horseback, yelling and cracking whips. Under Hawaiian law whipping was illegal, but it occurred nonetheless. ${ }^{34}$ Immigrant laborers were required to wear tags with their identity number on it. According to some workers, the foremen addressed them using their numbers and never their names. $^{35}$

Harvesting sugar was a labor-intensive activity. Workers used machetes to chop the twelve-foot high sugar cane stalks. Because of the sharp edge of sugar cane leaves, field laborers often left work with scratches covering their arms, this in addition to aching backs and blistered hands. The cane stalks were then gathered, bundled and brought to the mill where other immigrant workers processed the sugar in the factory's oven-like temperatures. After ten hours of work, another screaming siren signaled to the workers that they were free to go home. For this labor, Korean immigrant men earned on average fifteen dollars a month, a handsome income for

\footnotetext{
${ }^{34}$ Takaki, 135-140.

${ }^{35}$ Takaki, 135.
} 
some poverty-stricken Koreans, but significantly less than non-Asian immigrant workers. $^{36}$

Korean laborers, like other immigrants, most often lived in plantation housing. Lodging conditions varied widely. Some accounts tell of well-kept, well-built homes, with watertight roofs, proper drainage and flowerbeds. More often though, the housing was leaky, crowded and unsanitary. Sometimes workers slept in long barrack style warehouses on bunk beds stacked four or five high. In other situations two families were required to share a single room. Others lived in sheds with no beds at all, instead sharing sleeping mats spread on the floor. ${ }^{37}$ Descriptions given by Koreans in first-hand accounts describe close quarters with few luxuries. For example, Eun-Ai Cho recalled how neighbors shared kitchens and clotheslines. In order to provide privacy from their close neighbors, tenants applied butcher's paper to the cracks in the planked walls. ${ }^{38}$

According to historian Ronald Takaki, plantation living situations gradually got better after a four month long strike by Japanese workers in 1909 led to improved camp conditions. Planters provided more single-family cabins and plots of land for private gardening. They organized camp recreational options, like baseball, movie

\footnotetext{
${ }^{36}$ Patterson, The Korean Frontier, 93. See also Takaki, 151. Takaki claims that in 1909, Japanese workers received eighteen dollars a month, while Portuguese workers receive twenty-two dollars and fifty cents for the same work.

${ }^{37}$ Takaki, 158.

${ }^{38}$ Eun-Ai Cho, “A Follower of Dr. Rhee," Passages to Paradise: Early Korean Immigrant Narratives from Hawaii, ed. Daisy Chun Rhodes (Los Angeles: Academia Koreana, Keimyang University Press, 1998), 18.
} 
nights and musical events to curb the gambling habits of immigrant men. These changes corresponded with the increase of women on the plantations. ${ }^{39}$

Although laborers came from many places around the world, the camps were ethnically segregated. Harry Kay-Chal Yu, an early Korean immigrant, described, "The Koreans were like a community. All seven Korean homes were together in one area. All the other ethnic groups were housed near one another in their respective nationalities. That's how it was with Kahuku. There was a Spanish Camp, Filipino Camp, Japanese Camp and Korean Camp." ${ }^{40}$ Plantation accommodations were often hierarchal. The large, well-appointed house of the plantation manager rested on top of a hill. Directly surrounding it sat the nice homes of the Portuguese, Spanish and Japanese foremen. Below them were the simple, identical housing structures of the Asian camps. ${ }^{41}$

Segregation helped planters maintain control of their workforce. By dividing the nationalities, plantation owners may have hoped to prevent a sense of camaraderie and therefore reduce the chances of a unified strike. ${ }^{42}$ Furthermore, a system of segregation was simply pragmatic. It was far easier to direct a gang with one common language than a group with mixed languages. There is little evidence to

\footnotetext{
${ }^{39}$ Takaki, 160.

${ }^{40}$ Harry Kay-Chal Yu, "Escape Through Siberia,” Passages, 114-118.

${ }^{41}$ Takaki, 155.

${ }^{42}$ Eric R. Wolf says that segregation of social and cultural groups is a "hallmark of the industrial and plantation complexes constructed under capitalist auspices." Hierarchal and racial segregation, Wolf explains, maintains exploitive labor systems because it forces the lower (often ethnic) classes into competition with one another. Racial and ethnic segregation "serve to allocate different categories of workers to rungs on the scale of labor markets, relegating the stigmatized populations to the lower levels and insulating the higher echelons from competition from below." Europe and the People Without History (Berkeley: University of California Press, 1982), 380-381.
} 
suggest that immigrants opposed segregation as it allowed them to freely speak their language and practice their cultural customs; therefore, it is possible that planters may have had their workforce's comfort in mind when implementing segregated camp structures. There are some cases in which plantation owners purposefully mixed diverse nationalities in order to encourage solidarity instead of animosity among ethnicities. ${ }^{43}$ And in some instances Koreans did not live in separate camps simply due to their small numbers. ${ }^{44}$ The majority, however, remained segregated.

Within camp settings immigrants had opportunities to reinforce their national identities through festivities, religion and language. Chinese held lively New Years' celebrations, complete with lanterns, Chinese music, and firecrackers. The Japanese held a summer "festival of souls" where they dressed in kimonos and beat taiko drums and danced. Plantation churches provided space for groups to gather outside of the work setting. Japanese built Buddhist temples; Chinese and Koreans built Christian chapels. Sometimes different nationalities would share the same building although they would hold separate services. ${ }^{45}$ The churches served not only religious purposes, but social and educational purposes as well. Although children of plantation workers went to Hawaiian public schools they often attended language classes in the afternoon. Nam Young Chung, daughter of Korean immigrants, said, "They sent us [children] to church, where we socialized and had our ethnic language study for two hours each afternoon... So the social structure was that the Koreans

\footnotetext{
${ }^{43}$ Takaki, 157.

${ }^{44}$ Patterson, The Korean Frontier, 99.

45 Takaki, 162.
} 
would mingle among themselves and, likewise, other ethnic groups were with themselves. The only times groups interacted was at public schools."46

In this way, life on a Hawaiian plantation was both multicultural and divisive. Koreans, like other immigrants, encountered and interacted with people from many different nationalities in a way that was not possible in their homeland. At the same time, ethnically segregated living and working arrangements encouraged groups to identify with their nationality. ${ }^{47}$ Coming from notoriously homogenous Korea, Korean immigrants in Hawaii could construct an understanding of what they "were" in opposition to what they "were not" (i.e. Spanish, Filipino, Japanese, etc.). Their "Koreanness" then stood in stark relief. Plantation camps exemplified the paradox of multiculturalism. By living in a setting where a variety of languages, religions, and living habits coexist or collide, immigrants could more clearly define their unique ethnic identity. That is, by broadening their world experiences, they narrowed their concepts of self.

Koreans not only encountered national diversity on the plantations, they encountered regional diversity within their own camps. Life in America overturned many established social norms to which Koreans were accustomed in their homeland. Despite differences in culture, dialect and occupation, on a Hawaiian plantation, members of a diverse population lived very similar lives. They undertook the same jobs, earned the same wages, lived in the same neighborhoods and endured the same discrimination. Any previous social standing Asian immigrants might have had in

\footnotetext{
${ }^{46}$ Nam-Young Chung, "Always a Patriot," Passages, 35.

${ }^{47}$ Takaki, 150. Takaki illustrates this by describing how the labor unions organized themselves based on national identity (Japanese unions or Filipino unions) rather than class. 150.
} 
Korea had little sway in American society. And interestingly, although men constituted the vast majority of the Korean population, they lived in a setting where women's roles would be elevated and expanded. Among the many other social restructurings, Koreans in America also adjusted to changing gender roles.

Relocation to Hawaii and the United States drastically altered Korean women's social position for a number of reasons. In their new setting, Korean families relied more on women's labor and income earning jobs than in Korea. Western thinking, particularly Christianity, reshaped the ideals of womanhood among many Korean immigrants. And perhaps America simply attracted bold, Korean women - women who were willing to move away from their family, friends and mother country to seek greater possibilities abroad.

At the turn of the century, most women in Korea faced the social confines of early twentieth century Confucius values accepted by Koreans since the Yi Dynasty (1392-1910). Confucianism, as practiced by Koreans in the late nineteenth century, mandated the subordination of women in public and in the home. Established spiritual rituals exalted the special relationship between a father and son, thus encouraging the preference for boys over girls. Women were confined to their domestic spheres and not allowed in public during daylight and could only leave home in the evening if well covered. ${ }^{48}$ Their restriction to household tasks was not accompanied by a cultural reverence for a women's role as homemaker. Instead,

\footnotetext{
${ }^{48}$ Chan, Quiet Odyssey, xxxv-xxxvii. And of course, there were exceptions. Slaves who ran errands and did the washing could leave the grounds; and kisaeng, comparable to the Japanese geisha, received some education in music, classics and charm. Most Korean women, however, were brought up to accept Confucian ideals of subordinate femininity.
} 
tenets of Confucius patriarchy justified the demeaning position of women within the home. For example, although wives most often prepared the meals, common practice required women and girls to eat after the males of the household, therefore reinforcing women's position as servant to men.

Legally, women had few rights. They had no choice in who they married, nor could they divorce their husbands. Korean men, on the other hand, could legally divorce their wives for any number of reasons, including failure to bear a son, disobedience to the husband or the husband's parents and jealousy over the husband's extramarital relationships. Korean women could not own property, claim inheritance or receive an education. As a result, women were totally dependent on and subservient to the males in their lives, whether father, husband or son. ${ }^{49}$

Christian missionaries provided an alternative to strict Confucianism that was both timely and complimentary. In a time of wars and increasing foreign pressure from China, Russia, Japan and the West, Koreans coped with the stresses of political turmoil. In addition to poverty, the masses endured the difficulties of oppression by the higher governing classes. Confucianism, which emphasized strict adherence to established customs and roles, did not supply most Koreans with a spiritual or religious framework to make sense of their turbulent surroundings and rising dissatisfaction. According to historian Andrew Eungi Kim, Christian missionaries preached equality, worldly success and eternal life which provided for many a more useful worldview in light of modern circumstances than Confucianism. Kim argues that Koreans in the late nineteenth and twentieth centuries increasingly perceived

\footnotetext{
${ }^{49}$ Andrew Eungi Kim, "Political Insecurity, Social Chaos, religious void and the Rise of Protestantism in late nineteenth century Korea," Social History 26, No. 3 (Oct., 2001): 270.
} 
their traditional religions (Confucianism as well as Shamanism) as irrelevant. Therefore, Christianity did not contend with Confucianism as it filled a spiritual vacuum. ${ }^{50}$

The introduction of Christianity to Korea in the 1880s offered new concepts of women's roles that were neither extreme nor revolutionary. Protestant missionaries carefully integrated Christian teachings with established customs by emphasizing such values as honoring one's parents. A woman's subservient position to her husband was not directly challenged. ${ }^{51}$ Christian missionaries challenged traditional female roles through practice rather than overt indoctrination. For example, by opening the first schools for women and children of all social classes (boys and girls), missionaries overturned Confucius principals of denying education to women and the lower classes. Even more, Protestants in Korea promoted self-reliance of women and the under classes by utilizing the Nevius Method of spreading the gospel. This method required that Korean Christians raise funds to build churches and support their ministries. Koreans, including women, directed their own churches, whether it was proselytizing, holding bible groups or helping the needy. ${ }^{52}$

Christianity became popular with Korean women because it provided them with a public role, taught them literacy and allowed them to reconsider Confucian patriarchal traditions. Christian churches encouraged women to work for the church and as teachers. Missionaries taught women to read so that they could study the

\footnotetext{
${ }^{50}$ Andrew Eungi Kim, 274-275.

${ }^{51}$ Andrew Eungi Kim, 275.

${ }^{52}$ Andrew Eungi Kim, 278.
} 
bible, and encouraged them to visit neighbors and even travel outside of their hometowns in order to proselytize, a freedom of mobility previously foreign to them. Furthermore, Christian missions attracted Korean women because they accepted women who, by Korean standards, were considered outcasts. ${ }^{53}$

Religion was an integral part of the Korean American experience. A significant percentage of Koreans who arrived in the United States and Hawaii in the early 1900s were already Christian converts, partly because plantation recruiters targeted Korean Christians. ${ }^{54}$ Because Christianity was especially popular among women, most Korean immigrant women were already infused with progressive, Christian ideals before they emigrated. These new concepts of expanded female roles offered even more possibilities for Korean women in America. They did not have to struggle with established Confucian belief systems or religious discrimination in the same way as their mothers or sisters in Korea did. Korean immigrant women in America could more easily receive education, practice Christianity, earn income and fill leadership positions.

This is not to suggest that Korean women shed all notions of female subordination after adopting Christianity and moving abroad. Korean immigrants certainly had not relocated from a hierarchal society to an egalitarian one. Indeed, many narratives by second generation Koreans recall their mothers' secondary positions within the family. Immigrant women did not have the same rights and social standing as men, but neither did white women in America for that matter.

\footnotetext{
${ }^{53}$ Chan, Quiet Odyssey, xxxix.

${ }^{54}$ Patterson, The Korean Frontier, 93.
} 
Nonetheless, for Korean women the change was significant and the influence of Christianity was certainly an essential element.

In 1905, about 640 Korean women lived in Hawaii and the U.S. By 1924 there were about 2,000, still hardly an overwhelming number. ${ }^{55}$ Regardless, there are plenty of illuminative narratives that illustrate the lives of early Korean immigrant women in America. For example, there is Sook Chin Ahn. She moved to Hawaii in 1903 among the nearly 7,000 immigrants who arrived in the early 1900s, among the founding community of Korean Americans. Like many others, the American Christian missionaries in Korea supported and encouraged her immigration to Hawaii. Ahn was one of the less than 10 percent of women among the first wave immigrants.

A consideration of the life of Sook Chin Ahn is worthwhile. Her story illustrates oppression, desperation and building a new, more successful kind of life, an all-American story. Sook-Chin Ahn was not a picture bride. Many Korean women arrived as pictures brides between 1910 and 1924, and their accounts are indeed intriguing. Ahn, on the other hand, was recruited for plantation work rather than marriage. Ahn did marry, but not until her late thirties and to a man she knew, rather than a stranger. In these ways her story is unusual. Like most Korean immigrants, dismal circumstances in Korea motivated Ahn's move to Hawaii; like most Korean immigrants she worked in fields and in small businesses, her income vital for survival. And, like many Korean immigrant women her work and marriage

\footnotetext{
${ }^{55}$ Eun-Sik Yang, "Korean Women of America: From Subordination to Partnership, 1903-1930"
} Amerasia Journal 11 no 2 (1984): 1-3. 
in America reflected a broadening of traditional Korean gender roles. In these ways her story is representative of the collective.

In America, Ahn had little place to go but up. She was recruited to work in a sugarcane field but soon acquired a position as a housemaid. Perhaps this is not the most glamorous job by some standards, but Ahn did it well and was soon promoted to cook. She supported herself. In Korea it was rare for a woman to financially support herself. Back in Korea, Ahn had faced many obstacles. At seventeen Ahn married, but her husband died. She had one child; the child died too. She had no husband and no child (specifically no son) and therefore no status. She was eventually given to another husband who beat her. ${ }^{56}$ So Ahn acted bravely. She escaped to Seoul where she heard there were Christians who were taking care of the "hopeless and helpless." They were recruiting laborers to move to Hawaii-a clean break.

In a short time, she found herself baking apple pies and other American dishes for an American family in Honolulu. She remained single and supported herself for over fifteen years. At thirty-eight, she married Chi-Soon Kong, a forty-five year-old Korean tailor. But this took some convincing on his part. Ahn was reluctant to get married, perhaps because her past marriages were less than happy and because, as she claimed, she could not have children at thirty-eight. According to Ahn's daughter, Kong was persuasive. “We need each other. We'll just grow old together. Don’t worry about children," he is claimed to say. So they had an inexpensive wedding.

\footnotetext{
${ }^{56}$ Inez Pak-Soon Kong, "Walking a Hundred Miles" in Passages, 58. The text is unclear as to who "gave" Sook-Chin Ahn to her husband. It was most likely her parents who, under Confucian customs at the time, dictated the marriages of their daughters. Andrew Eungi Kim, 270.
} 
Ahn become pregnant the next month. She had a boy and three years later, a baby girl.

Sook-Chin Ahn did not write her story herself. It is likely she could not. Many Korean immigrants never mastered the English language and many more never received proficient education in America or Korea. Both factors would impose challenges to any would-be writer. And perhaps her story did not strike her as one worth telling. ${ }^{57}$ Often the first-hand narratives available were first conceived not by story-writers but by eager story-seekers-historians, anthropologists and sociologists who went searching for interviews and encouragingly baited promising memoirists. In Sook-Chin Ahn's case, there was no biography enthusiast coaxing from her a life narrative, as interesting as that could be. Instead her daughter, Inez Pak-Soon Kong, recounted her mother's story for her. In her own personal narrative Kong begins her life story by first telling about her mother's.

It is useful to consider what Kong included in her narrative about her own life growing up in Hawaii, but also specifically what she included (and did not include) about her mother's life story. How did she attempt to portray her mother and, in turn, Korean immigrants? Considering Daisy Chun Rhode's project of collecting early immigrant narrative histories, one might suspect that Kong hoped to cast a heroic light on her mother's story and thus on early Korean immigrant history in general.

\footnotetext{
${ }^{57}$ Soo Young Chin says that autobiographies are an invention of the West (Europe and the United States) where there is a strong emphasis on the individual. In China and Korea, autobiographical pursuits, especially in the early twentieth century, would be deemed egotistical. Autobiographies, then, were culturally foreign to early Korean immigrants. Introduction to Doing What Had to be Done: The Life Narrative of Dora Yum Kim (Philadelphia: Temple University Press, 1999), 6.
} 
There is no definite way to uncover the biases under which narrators present their stories, but with these issues in mind one can proceed cautiously and thoughtfully.

Kong's account of her mother is not lengthy or embellished. It is not weighed down with emotive words. This is no weakness as narratives go. In fact, its simplicity is actually its strength for it means fewer judgments to interpret, less debris through which to wade. Take Kong's account of her mother's younger years:

In my mother's case she was given to a man who was a wife beater. He abused her terribly and she escaped all of that by walking out of Kangwon-do which is not far from Kumkang Mountain./...My mother, who was then twenty-two years old, walked about a hundred miles to connect herself with missionaries who were recruiting laborers to go to Hawai' ${ }^{5}{ }^{58}$

There is nothing more that needs to be said to sympathize with that situation. One need not be an analytical expert to understand that this journey (first a hundred miles, then across an ocean) was both harrowing and brave, or risky and adventurous.

Inez Pak-Soon Kong may have only provided the skeletal outline of her mother's life, but it is enough to make out that her mother was a woman who eschewed established gender roles. Ahn left Korea in a bold way. There is no mention of her parents or her in-laws in her story, but it is doubtful they would have supported her abandoning her husband, much less adopting Christianity and leaving her homeland to work on a Hawaiian plantation. In Hawaii, she remained single and then married a man of her choice, again exercising a freedom seldom available to women in Korea. She became a businesswoman in America when she and her husband opened and ran a small shop together.

${ }^{58}$ Kong, 58. 
Even if Kong offered the most dramatic aspects of her mother's life history, the events and their emotional importance are still significant. Ahn's story tells of her social and economic hardships. Other accounts show that Sook-Chin Ahn's struggles are not incongruous but instead reflect the desperate situation of many Koreans at that time. Mary Paik Lee, for instance, told how her father struggled with the decision to move to Hawaii in 1905. She remembered, "Father was reluctant to leave, but his parents insisted, saying that his presence would not help them. They knew what would happen to them in the near future and were prepared to face great hardship or worse, but they wanted at least one member of their family to survive and live a better life somewhere else." ${ }^{59}$ Considering the difficulty of breaking with established kinship networks, mass immigration is a strong indication of bleak conditions in Korea. In fact, Patterson credits bad conditions in Korea (rather than the search for adventure, for example) as the most compelling motivation for moving to America. ${ }^{60}$

For many Korean women, like Sook Chin Ahn, emigration meant greater personal agency albeit through financial necessity. As in Korea, most Korean women in America were poor; however, unlike in Korea, women could contribute economically to the family income in jobs outside the home. Even on plantations, women were not confined to the fields but could work as cooks, laundresses or seamstresses. ${ }^{61}$ Lee's family history demonstrates this well too. Although her father "did not like her to work," Lee's mother earned money as a cook to help support the

\footnotetext{
${ }^{59}$ Mary Paik Lee, Quiet Odyssey: A Pioneer Korean Woman in America (Seattle, University of Washington Press, 1990), 12.

${ }^{60}$ Patterson, The Korean Frontier, 111.

${ }^{61}$ Takaki, 135.
} 
family. ${ }^{62}$ Taking income-earning jobs not only expanded women's roles beyond the home, it potentially allowed them more leverage concerning family finances.

According to Alice Yun Chai, Korean immigrant women controlled their own income since they were often the major providers for their families. By borrowing money from kyes, money-lending unions established exclusively for and by Korean women, they had the means to finance their own endeavors independent of men. ${ }^{63}$ Certainly, Korean women did not trade a life of toil for a life of ease upon moving to America, but in comparison to Korea, where women were "denied any socially meaningful status [and] women's activities were mostly restricted to the home," life in America imposed far fewer social and economic restrictions. ${ }^{64}$

In the few decades after they arrived, women comprised just less than 10 percent of the Korean immigrant population. This disproportion of numbers shifted male-female relations. Although I have come across no evidence to support it, there is the possibility that their being severely outnumbered may have subjected women to instances of suppression and abuse. ${ }^{65}$ And, for the most part, their lives remained domestically centered which may seem to indicate that nothing had changed from Korea to America. Yet what Ahn's and other life stories portray is a greater

\footnotetext{
${ }^{62}$ Lee, 14.

${ }^{63}$ Alice Yun Chai, “Women's History in Public: 'Picture Brides' of Hawaii” Women's Studies Quarterly. 16. No. 1/2. (Spring/Summer 1988): 56.

${ }^{64}$ Andrew Eungi Kim, 270.

${ }^{65}$ Yang, 6. Yang does not claim that abuse towards women existed but she does say that given the uneven sex ratio, Korean wives became the object of envy and that instances of seduction did occur. Korean men formed the fraternity, tonghoe, "partly out of the necessity to protect the women..." Whether this is protection from seduction or acts of violence is unclear.
} 
opportunity for choice and the ability to live openly including in patriotic and political realms.

The disparity between Korean male and female populations decreased slowly through the years. U.S. anti-Asian policies helped this process. The 1907 Gentlemen's Agreement between Washington and Tokyo severely limited Japanese as well as Korean immigration by only allowing family members of already present immigrants to enter America. This provided an opportunity for Korean and Japanese women to enter America as the wives of immigrants who were already living in Hawaii and the continental United States. They took advantage of existing laws that allowed them to emigrate legally and arrive in America as picture brides. Korean women had to be authorized by the Japanese government to which they were legal subjects. Although a few years earlier the Japanese government resented the influx of Korean laborers to Hawaii because it hindered the Japanese workforce's power to strike, when it came to the emigration of Korean picture brides, the Japanese government was supportive. Knowing that anti-Japanese colonial sentiment was on the rise among Koreans in America, Japanese officials hoped the arrival of Korean women would have a calming effect, or at least divert the attention of America's politically disquieted Korean population. ${ }^{66}$ They could not have known that Korean women would become a driving force behind the Korean Independence Movement abroad.

Along with Christianity, the emigration of a large number of picture brides was an important contributing factor that helped shape the Korean immigrant

${ }^{66}$ Lee Houchins and Chang-su Houchins, "The Korean Experience in America, 1903-1924” The Pacific Historical Review 43, no. 4 (November 1974): 559. 
experience in the first half of the twentieth century. First, they comprised a significant percentage of Korean women who arrived in the founding years of Korea immigration. Moreover, with the introduction of Korean picture brides into a maledominated population, Korean communities became more permanently established because they created families. Additionally, they altered the traditional role of Korean women and increased their opportunities for public and personal agency. Picture brides were most often young women who agreed to marry a Korean man based on the favorable exchange of photographs. Some parents encouraged the marriage; other women chose to become picture brides to earn money for their family in Korea. ${ }^{67}$ Others simply wanted a way to escape the socially and politically oppressive situation in Korea or to get an education. ${ }^{68}$ The wedding ceremony sometimes took place in Korea without the groom. Thereafter, the bride sailed to Hawaii (as was most often the case) or the continental United States to meet her legal husband and begin a life with him. Alternately, the wedding ceremony would take place after a matchmaker arranged the engagement and the bride arrived in America.

They were termed "picture brides" because the men and women had often traded nothing more than their photographs prior to marrying. Unsurprisingly, this method of matchmaking created disappointments for a number of the picture brides. Like the immigrants who arrived expecting quick wealth and success, many Korean girls entered into wedding contracts envisioning a comfortable life with their rich,

\footnotetext{
${ }^{67}$ Carol C. Fan, "Asian Women in Hawai'i: Migrations, Family, Work, Identity” NWSA Journal 8, no.1 (Spring 1996): 75.

${ }^{68}$ Houchins, 566.
} 
handsome, young husbands-a vision that the matchmakers promoted. ${ }^{69}$ Several first-person accounts, however, describe the devastation some women felt upon first meeting their husbands. Mrs. Kim explained her reaction when, at nineteen, she met her husband for the first time. "He came to the pier, but I see he's really old, oldlooking. He was forty-five years old, twenty-five years more old than I am. My heart stuck. I was so disappointed. I don't look at him again." She refused to speak to her husband for three months.

Although some women did run away or refuse their husbands, most found that their best option was to remain in the relationship. And it must be mentioned that many women were pleased with their matches and some who were initially disappointed developed loving relationships with their husbands over time. Mrs. Kim, too, had a change of heart. "After three months, well, God gave me my life, I can't help him being too old. I cooled down, make everything nicely, make each other talk."70

With an unbalanced male to female ratio among Korean immigrants, acquiring a picture bride became the most logical way for a Korean man to find a Korean wife and it provided opportunities for women in Korea who had few other legal means to move to America. Korea had a long history of arranged marriages and matchmaking, so the institution of picture brides was not unfamiliar. Arranged marriages can easily be conceived as a means of subordination because they deny

\footnotetext{
${ }^{69}$ Wayne Patterson, The Ilse: First Generation Korean Immigrants in Hawaii 1903-1973 (Honolulu, University of Hawaii Press, 2000), 83.

${ }^{70}$ Alice Y. Chai, “'Mrs., K': Oral History of a Korean Picture Bride,” Women's Studies Newsletter 7 , no. 4 (Fall 1979): 11.
} 
people (mostly women) the choice of their own spouse. The accounts of young picture brides who were overwhelmingly disappointed with their mates and yet felt virtually powerless to leave could suggest that Korean women had little control over their fate. Yet, for women like Mrs. Kim, choosing to be a picture bride was an act of bold autonomy, for most of these women did choose to become picture brides and were thus able to emigrate.

The arrival of Korean picture brides helped create a Korean American community with stark differences from those in Korea in several ways. First, overseas matchmaking facilitated further mixing of social and geographical groups. Rachel Sung-Sil Kim, the daughter of a picture bride, explained her mother's marriage difficulties. In addition to being much younger than her husband, she had come from southern Korea while her husband had come from the north. This created cultural and language barriers. Furthermore, she had come from a more educated class of people and was not accustomed to strenuous physical labor. ${ }^{71}$ The socially disparate mixing required Korean immigrants to move beyond previously accepted social boundaries in their new American setting.

By entering into arranged marriages, Korean women also inadvertently changed their public roles in society as well. Many of these women, for example, married older men who often died much earlier than their wives. This is significant because it meant that women became the breadwinners for their households. They often took over their husband's small businesses and in this way became financially indispensable. In Korea, although poverty forced many women to work, their

${ }^{71}$ Rachel Sung-Sil Kim, "What Have We Done,” Passages, 98. 
traditional Confucian belief systems regarded women's contribution of little value. ${ }^{72}$ In America, Korean women were able to gain status through work. Certainly, Sook Chin Ahn would not have considered her work of little value as it afforded her the opportunity to live independently. After she chose to marry she and her husband opened a store which they ran together. Similarly, Mrs. Kim also worked, her income vital to the family. When her husband died, she succeeded as a businesswoman, running a laundry shop, owning a boarding house and later building and running apartment units.

The expansion of Korean women's roles in America arose from a combination of factors. One could argue that their social incline corresponded directly with the necessity of their income-earning work. Another factor may be that women had more liberty and feelings of self-worth having separated themselves from Confucian culture, including the demeaning position of having to serve not only men, but mothers-in-law as well. Considering that the majority of Korean immigrants in the early twentieth century were young or relatively young bachelors, this meant there were very few older Koreans to try and impose traditional Confucian values. Of course, one could simply argue that the nature of settling abroad attracted bolder, more independent women. In this case it was not so much the new environment that prompted the expanded roles, but rather it was that these women had arrived more liberally minded (whether from growing up in a progressive home or having been influenced by Christian missionaries) and so with other likeminded Korean women came to form a community of progressive females.

${ }^{72}$ Andrew Eungi Kim, 270-271. 
Whatever the reasons, within the first few decades of settling in the United States and Hawaii, the lifestyles and social habits of Korean women in America differed considerably from their relatives in Korea. They demonstrated this through their occupations and marriages. Another important way in which women expressed their new sense of autonomy was by becoming activists for Korea's independence.

The Korean Independence Movement was just taking shape as Koreans first began settling in America, but nonetheless provided Korean men and women with a foundation on which to structure their new lives in America. Upon leaving their support systems in Korea, and then joining populations of immigrants with widely different backgrounds, one of the ways Koreans sought common grounds was by focusing on their Korean patriotism — that is, their support for Korean independence and pride in their national heritage. By focusing on the Japanese as a foreign enemy they could easily identity as a group based on ethnic and national identities.

Participation in Korean patriotic clubs was the most common way Koreans supported the independence movement. Patriotic clubs reinforced Korean social bonds through organized activities. According to the Korean scholar Pyong-Suk Yun, Korean nationalist activities in America officially began soon after activist leader An-Ch'ang Ho arrived in San Francisco in September, 1903. Although there were only about twenty-five Korean immigrants in San Francisco at the time, An organized a social group, the Friendship Society, with the purpose of aiding and acculturating newly arrived immigrants. The group consisted mainly of students and a few ginseng merchants in the area. ${ }^{73}$ The Friendship Society took a distinctly

${ }^{73}$ Pyong-Suk Yun, seminar speech in Los Angeles, CA, February 22, 1994. 
political slant when Japan became the protectorate of Korea in 1905. Anti-Japanese sentiment rose among Korean immigrants and it was then that An recognized the necessity of forming an organized reform movement. ${ }^{74}$ The group, renamed the Mutual Assistance Association (Gonglip-hyuphoe), published and dispersed informational newsletters to inform its members of pressing Korean issues including colonial occupation and the brutality of Japanese forces in Korea. ${ }^{75}$ Within three years, six local branches existed throughout California and membership rose to about 130.

Patriotic clubs proliferated in Hawaii where there were approximately twodozen groups serving political activist goals. In 1903, Koreans in Honolulu founded the New People Society (Sinmin-hoe) to protest Japanese occupation of Korea. In addition, there was the New Korea Society (Sin'ganhoe), the Restoration Society

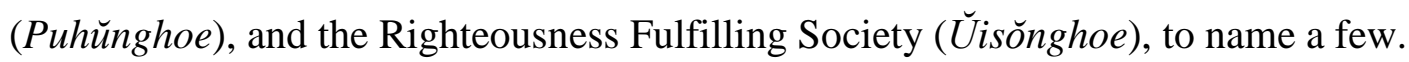
In 1909, the United Korean Society in Honolulu joined efforts with the Mutual Assistance Association of San Francisco to create the Korean Nationalist Association (KNA), the most well-known and active patriotic club thereafter. ${ }^{76}$ At the time, there were 116 branches of the KNA, seventy-eight of which were in Hawaii. The majority of Koreans in America were members of the KNA; therefore the KNA's aim was to

\footnotetext{
${ }^{74}$ Houchins and Houchins, 566. There is some disagreement here. Pyong-Suk Yun claims that the Friendship group was political and anti-Japanese in nature from nearly the beginning, while Houchins claims that it became distinctly political only in 1905.

${ }^{75}$ Pyong-Suk Yun, seminar speech.

${ }^{76}$ Chan, Quiet Odyssey, xlviii.
} 
build power in numbers, or at least power through financial means considering membership to the KNA required club dues. ${ }^{77}$

Other clubs were more selective in their recruitment of members. An Ch'angho, the founder of the Friendship Society, founded another political group in 1913. Similar to his earlier group, the Corps for the Advancement of Individuals (Hungsadon) was comprised of students. An Ch'ang-ho interviewed prospective student members personally before encouraging them to join. The Corps for Advancement of Individuals was patriotic from its inception. According to one student, An insisted on the utter importance of restoring Korea to its independent state and the importance of Korean unity. However, An's group specifically espoused anti-radicalism. Instead, he believed in the cultivation of individual character. An hoped that through leadership, educational and character training, the club would create students who would become effective leaders against Japan and in the restoration of Korea. $^{78}$

From these clubs emerged many periodicals that helped distant branches communicate and informed members of local and international issues. Houchins claims that more than thirty periodicals existed in America and Hawaii from 19031924. Most were short-lived due to financial limitations and factionalism. Unsurprisingly, the KNA distributed the most well-known and enduring periodical. The first issues, under the title Korea News (Tongnip Sinmun), came out in 1905; in

\footnotetext{
${ }^{77}$ According to Lee Houchins all Koreans in America were required to join the KNA although he does not explain how enrollment was implemented. I have not come across this fact in any other source however it would help explain the KNA's enduring success as members were required to pay dues. Houchins, 566.

${ }^{78}$ Houchins, 567.
} 
1910 the name was changed to the New Korea (Sin-Han Minbo). Other less successful but nonetheless prominent periodicals included the Korean Pacific Weekly and United Korean News. According to Houchins nearly all of the periodicals addressed political themes and were designed to inspire patriotism. Prominent leaders of the K.I.M. in America, such as Syngman Rhee and An Ch'ang-ho, contributed articles. ${ }^{79}$ These periodicals were instrumental in guiding the Korean Independence Movement and were a vital source of information as well as propaganda for Korean immigrants. In addition, by providing current and pressing news about Korea, printed publications helped Korean immigrants feel connected to their homeland. By reading the same headlines and reports about Korea, periodical created a shared connection that reinforced Korean identity and bolstered their sense of community.

The quick demise of periodicals reflects the disorganized nature of early patriotic efforts. Several scholars suggest that factionalism was a great weakness in the K.I.M. in early years. ${ }^{80}$ In comparison with the highly organized politically zealous club activity that would emerge in 1919 in response to the March First Movement, the founding clubs were relatively rudimentary. Overseas Korean patriots would not develop a cohesive resistance movement until 1910 when Japan officially colonized Korea. This event provided the culturally diverse and geographically scattered Korean population throughout America with a shared focus. The

\footnotetext{
${ }^{79}$ Houchins, 568-569.

${ }^{80}$ For example Wayne Patterson, The Ilse: First Generation Korean Immigrants in Hawai'i 1903 1973. (Honolulu, University of Hawai'i Press, 2000), 53. and Pyong-Suk Yun, seminar speech in Los Angeles, CA, February 22, 1994.
} 
colonization of 1910 invigorated community-building efforts by connecting Koreans throughout America with a clear, cohesive, nationalistic goal—Korean Independence. Japanese colonization raised Koreans' anti-Japanese sentiment and signified an evolution in Korean American thought. Thereafter, Koreans became increasingly united in their patriotic clubs, particularly the KNA.

During this time women founded gender exclusive clubs suited to their particular goals for Korean independence. The Korean Women's Society and the Korean Women's Association, for example, both had branches throughout California. Little information exists about these early Korean women's groups, particularly in English. However, according to historian Eun Sik Yang, who consulted sources in Korean, these early groups' stated purpose was to maintain Korean language education for children, to be involved in Christian church activities and to encourage Korean solidarity. The Korean Women's Society appeared slightly more political than the Korean Women's Association by specifically encouraging Koreans to boycott Japanese products. ${ }^{81}$ Sources that I have consulted do not mention women's patriotic clubs in Hawaii prior to 1919, although they probably existed considering that the largest population of Korean immigrants lived in Hawaii and as some firstperson accounts from early Korean immigrant women mention early activism and women's clubs. ${ }^{82}$

\footnotetext{
${ }^{81}$ Yang, 12.

${ }^{82}$ Rachel Sung Sil Kim, for example, says this about her mother: "Making a living and surviving became my mother's preoccupation while using her education within the community and at the Women' Society at church." She does not say any more about this women's society nor does she provide exact dates however the general chronology of her account suggests that her mother participated in church and women's society activities from at least the mid 1910s. Rachel Sung-sil Kim, "What Have We Done?" 99.
} 
Yang claims that these women's groups played a minor role in the Korean Independence Movement until 1919 when the March First Movement ignited Korean desire for independence on a global level. This can be partially attributed to the low numbers of Korean women. In addition, perhaps within the first ten to fifteen years of immigration Korean women simply had not been separated long enough from the conservative Korean culture to feel comfortable holding overtly open and political roles. Their participation in these founding clubs is nonetheless important. For many years women had been active in the Christian church, serving as deaconesses, stewardesses and teachers and organizing church activities. Yet women's contribution in the churches remained secondary to the leadership of men. ${ }^{83}$ With the founding of women-only clubs, women were able to fill leadership positions and run the organizations in the manner they saw fit. This is important because these clubs were a prelude to the women's groups that would soon after become a driving force of the Korean Independence Movement. Even more, by organizing and leading political clubs, Korean women were slowly integrating into American culture, one that was more accepting of women in the public sphere than early twentieth century Korea. Efforts in the name of nationalism became a means of acculturation.

Senses of community and nationalism are able to inspire great movements and emotion within large groups of people. Yet, the terms "community," "nationalism" and "patriotism" must be handled judiciously for at least they are vague terms, at most widely debated concepts. Here, Benedict Anderson's Imagined Communities: Reflections on the Origin and Spread of Nationalism is useful. Anderson's pivotal

${ }^{83}$ Yang, 12. 
work is now bedrock among serious theoreticians on nationalism. Imagined

Communities addresses the rise of the nation-state and nation based identity that arose in the eighteenth century and matured in the nineteenth century. Anderson argues that nations are based on fabricated concepts of community because most members of the nation-state community will never know each other; to be sure, the majority will never even know of each other. ${ }^{84}$ Members of a nation feel united through a consciously fashioned history and by politically drawn boundaries, despite differences in local culture, social background, and occasionally language. ${ }^{85}$

The fervent loyalty with which many members will dedicate themselves to an imagined community, even to the point of giving up their lives, is remarkable according to Anderson. People belong to many different imagined communities, such as political parties or labor unions; yet, it is quite uncommon and hardly widely accepted for one to willingly die for their left wing liberal party. The dedication to nation-state is particularly strong, says Anderson, because it seems natural and one's fate. Patriotic sentiment is not unlike the connection one feels towards family with its deep sense of obligation, inheritance and pride, and for whom it is conceivable to sacrifice one's life. ${ }^{86}$ For populations to hold similar feelings—-pride, protectionism,

\footnotetext{
${ }^{84}$ Benedict Anderson, Imagined Communities: Reflections of the Origins and Spread of Nationalism (New York: Verso, 2006), 6.

${ }^{85}$ Anderson, Imagined Communities, 205. Anderson compares national histories to personal biographies explaining that we (personally and collectively as nations) cannot actually remember much of our history. Therefore we trustingly rely on others to tell us our past, that we are the baby in the photo and that we did behave certain ways as a child. Anderson argues that nations seek and therefore construct (for not every detail can be included in personal and national histories, therefore a selection process is necessary) a story of the past in order to serve "the need for a narrative of 'identity."

${ }^{86}$ Anderson, Imagined Communities, 144.
} 
loyalty — for their intimate family as well as thousands and millions of people they do not know is profound. Imagined Communities, first published in 1983, was not the final word on nationalism and Anderson's breakthrough work has not been left uncontested ${ }^{87}$ However, for this study Anderson's theories are appropriate and insightful in helping to reveal complexities concerning Korean immigrant patriotic endeavors.

To further a discussion on these themes, it is necessary to first clarify useable definitions for "community," "nationalism" and "patriotism." According to Anderson communities are groups of people bound by a sense of comradeship that exists despite the inequality and mistreatment that may exist within the community. All communities, except for those of "primordial villages of face-to-face contact" are imagined. The "nation," which Anderson and others have admitted is difficult to clearly define, is the "imagined political community." It is imaginary in that the members must accept and believe in the constructs that define the nation. However, this in no way negates the "profound emotional legitimacy" of nationalism. ${ }^{88}$ Patriotism, unlike nationalism, is not the identification with a shared past. Instead, patriotism refers the admiration and loyalty one feels for the values, actions and institutions of a nation. These understandings of community, nationalism and patriotism help to explain why the Korean sense of community in America was not necessarily inherent; rather it was consciously bolstered, performed, even

\footnotetext{
${ }^{87}$ One can find an abundance of material contesting certain aspects of Benedict Anderson's assertions in Imagined Communities, such as Sara Castro-Klaren and John Charles Chasteen in Beyond Imagined Communities: Reading and Writing the Nation in Nineteenth Century Latin America (Baltimore: Johns Hopkins University Press, 2003) which attempts to offer a different view on how nationalism developed in the Spanish American colonies.

${ }^{88}$ Anderson, Imagined Communities, 6.
} 
exaggerated. Furthermore, applying Anderson's ideas to Korean immigrant nationalism can illuminate what drove their patriotic fervor.

Anti-Japanese sentiment was the most apparent factor that propelled the K.I.M. during the earliest years of Korean settlement. When the Japanese entered Korea with intent to take over politically and culturally, Korean identity was threatened. An enemy disrupted the very things upon which nations have historically built their identity—language, shared history, culture and politically drawn boundaries, according to Anderson. When the legitimacy of nation-states was recognized globally at the start of the twentieth century, Koreans found whatever shaky foothold they had in the international community to be in jeopardy. Although Korea may have been politically old-fashioned at this time (with a monarchy and having only implemented an accessible form of writing within the last few decades of the nineteenth century), ${ }^{89}$ Koreans were undoubtedly aware that the Japanese were stripping from them their political legitimacy—and hence their identity.

Their new American setting strengthened Korean nationalism in two important ways. First, immigration to America placed Koreans in a multicultural setting in which they were the stark minority. Living within racially mixed camps, Koreans could not have felt more Korean. They also could not have helped but to feel unrecognized. Koreans were the smallest population within an Asian minority; they were commonly mistaken for Chinese and Japanese, and the American government acknowledged Japanese colonization and Koreans as Japanese subjects.

${ }^{89}$ Andrew Eungi Kim, 277. 
This combination of alienness and obscurity inspired many to seek support through Korean nationalism.

Secondly, as they moved away from their established communities in Korea, Korean immigrants were drawn to nationalistic pursuits to create a new community. Koreans in America made conscious efforts to construct a new community. Korean Friendship Clubs sprouted up almost as soon as the first shipload of Koreans arrived. When anti-Japanese sentiment began to grow they used it as a powerful a rallying point.

Korean nationalism abroad provides an interesting point for consideration. Unlike Koreans in the homeland, those living in America were removed from the political crisis, at least physically. Considering that nations and feelings of nationalism are in part based on the belief of the legitimacy of political borders, one might assume that Koreans would be less patriotic than their relatives at home, they had one less imaginary construct that applied to them. In other words, having removed themselves from the political boundaries they may have been less concerned with the political welfare of that country. This is not the case however, with Koreans or many other nationalist movements that took place out of the country of origin.

The development of a heightened sense of nationalism away from the country of origin is not an isolated or unfamiliar occurrence. Some scholars have suggested that strong fixation with the home country is a response to the rough transitions of emigration. To counteract feelings of alienation, immigrants often develop a strong sense of national pride. Benedict Anderson coins this relatively common occurrence 
as "long-distance nationalism." ${ }^{90} \mathrm{He}$ refers to immigrants who use their residence abroad as a base to bolster their nationalist cause. In his discussion, he refers to the Tamils, the Croats, and "the fanatical adherents of an independent Khalistan," who organize in places like North America, Australia, Germany and Great Britain. Citizens of poor, less stable countries commonly take advantage of living in wealthy nations to protest in relative safety. Living abroad also allows them to organize without being preoccupied with scarcity, death, fear, and the many other distractions of war. Much of the K.I.M.'s success was strongly linked to the difficult experiences associated with immigration, like poverty, isolation and discrimination.

Like many immigrants, Koreans who relocated to the United States and Hawaii often dreamed of moving back to Korea. First-person accounts relate their long-distance attachment to Korea, particularly among those immigrants who arrived in the early 1900s. Nam-Young Chung's narrative described how his father had remained forever loyal to Korea. "My father was always a patriot and a freedom fighter. He not only donated to the cause but also wrote articles, participated in antiJapanese activities for the freedom of his country. From childhood we were made to understand that we were foreigners in this country. We would have to return to Korea when it was liberated." ${ }^{91}$ Chung's family, like most Korean immigrant families never did move back to Korea.

Because of economic struggles, political instability and other difficulties of moving abroad, very few Koreans were ever able to return to their native country.

\footnotetext{
${ }^{90}$ Anderson, "Exodus," 326.

${ }^{91}$ Nam-Young Chung in Passages, 36.
} 
Unlike early twentieth century Chinese and Japanese immigrants of whom at least half returned home, only one in six Korean immigrants living in the United States and Hawaii moved back to Korea. A main factor for this was the distressing and dangerous political situation of Korea in the first half of the twentieth century. As of 1910, when Korea became an official colony of Japan, Koreans living abroad considered returning home a disturbing prospect. ${ }^{92}$

Since the first Koreans arrived in Hawaii in significant numbers by 1905, certainly their accomplishments were coupled closely with challenges. Korean immigrants suffered because of anti-Asian sentiment, but were free from Japanese authority. They escaped the poverty of Korea but still lived meagerly by American standards. They were free to demonstrate their nationalism in ways Koreans in the homeland could not. In comparison to their lives in Korea, they were relatively successful. Women in particular had opportunities for advancement. Although many did not fulfill their dreams of education or overturned Confucian patriarchy, they did, as Sook Chin Ahn and Mrs. Kim's life stories reveal, expand their roles in meaningful ways. The focus for this first wave of immigrants was to build a sense of Korean community, which they did through patriotic clubs and nationalist activism. The Korean Independence Movement not only helped Koreans build a sense of community within America, it also helped provide the means for them to assert their individual nationality and culture.

\footnotetext{
${ }^{92}$ Roberta Chang W.S., The Koreans in Hawaii: A Pictorial History 1903-2003 (Honolulu, University of Hawaii Press, 2003), vii.
} 
"It is always a mistake for a man trying to follow idealism and ignore the power of nationalism",93

Henry Chung

\section{Chapter Two \\ The 1919 March First Movement: \\ Americanization and Internationalization of Korean Immigrants}

The year 1919 was full of unrest. Having just emerged from a world war, many countries around the globe sought redemption, restoration and, in some places, liberation from their colonizers. The 1919 Paris Peace Conference confronted these issues for some of the world's population. Korea numbered among the several nations who hoped to secure a place in the international limelight, to utilize post-war idealism. 1919 was also the time of the March First Movement in Korea, a failed attempt by Korean nationals to secure independence from Japan. This event, more than any other in the Korean Independence Movement, inspired Korean patriotism and nationalism globally, particularly in America. The March First Movement reflected the post-World War I beliefs that every person had a right to belong to his or her own independent nation-state. Korea, known as the "Hermit Kingdom" less than fifty years earlier, was now fighting for a respectable place in the modern, international world with the help of emigrants throughout the world.

By 1919, Korean patriotic activities in America had taken a different appearance than the earlier period at the turn of the century. During the earliest years of Korean settlement, participation in the Korean Independence Movement

${ }^{93}$ Henry Chung, interview by Sonia Shinn Sunoo (7 January, 1979). Korean Kaleidoscope: Oral Histories, Volume One, Early Korean Pioneers in USA: 1903-1905, transcript, Korean Oral History Project Series 1, Sierra Mission Area, United Presbyterian Church, USA (1982): 72. 
established a sense of community and solidarity for immigrants. But time had modified Korean immigrant life so that by 1919 , they no longer needed to replace lost kinship networks as they created families, opened small businesses and expressed greater patriotism towards their host country.

This chapter examines how the Korean community adopted American notions of independence to understand and broadcast their movement for Korean independence. This coincided with a deepening loyalty and patriotism towards America. Korean nationals expressed these sentiments during the 1919 Korean Congress in Philadelphia, demonstrating that their Korean patriotism did not clash with, but in fact complimented, their strong patriotism for America. Their words attested to their political and social goals for recognition as well as their social advancements, particularly those made by Korean immigrant women. The Congress demonstrated that, by 1919, Korean immigrants increasingly looked to the American government and public for support as well as acceptance instead of looking solely inward within the Korean community to establish support networks.

From 1903 to 1907, Korean bachelors working on plantations made up most of the Korean community in America and Hawaii. By 1919, there was a shift in Korean gender and occupational demographics in Hawaii and America. The arrival of just over 1,000 Korean picture brides between 1910 to 1924 narrowed the discrepancy between male and female ratios in the Korean American community. Historian Eun Sik Yang concluded that prior to 1910 the ratio was 1,380 males for every 100 females. After the influx of picture brides (along with the birth and maturation of American born Korean girls) the ratio narrowed to 225 males for every 
100 females in Hawaii and 300 to 100 on the mainland. ${ }^{94}$ Moreover, the migration of workers from plantations to cities restructured Korean demographics. Some Koreans continued to work in agriculture; increasingly, however, more Koreans left plantation work for other occupations. In fact, Korean immigrants had one of the highest rates of urbanization among the ethnic groups working in Hawaii. ${ }^{95}$ Many operated their own small businesses such as restaurants, barbershops, or produce stands. ${ }^{96}$

Korean communities gradually became more urban, but this did not mean the economic situation of Korean families had improved significantly. Koreans switched to urban jobs because they often paid better than field labor, but as the size of families grew (Korean couples at that time had on average five to ten children ${ }^{97}$ ), so did expenses. Rachel Sung-Sil Kim, a first generation Korean American, described her family's move to Honolulu after leaving a plantation at Kohala. According to Kim, her father started working as a store clerk and soon opened his own grocery store because "having a store was what he thought would support the family." Her mother also worked selling dresses, but still the store did not survive more than two years. When Rachel Sung-Sil Kim was ten and her sister eight, they began packing fruit boxes to earn money for the family. ${ }^{98}$

\footnotetext{
94 Eun Sik Yang, "Korean Women of America: From Subordination to Partnership, 1903-1930," Amerasia Journal 11 no 2 (1984): 8-9.

${ }^{95}$ Wayne Patterson, The Korean Frontier in America: Immigration to Hawaii, 1896-1910 (University of Hawaii Press, 1988), 122.

${ }^{96}$ Yang, 9.

97 Yang, 7.

${ }^{98}$ Rachel Sung-Sil Kim, "What Have We Done?" Passages to Paradise: Early Korean Immigrant Narratives from Hawaii, ed. Daisy Chun Rhodes (Los Angeles, CA: Academia Koreana, Keimyang University Press, 1998), 99-101.
} 
John Young-Ahn Kim also described the various jobs his father undertook in order to support his family: "During the earliest stages of our lives on Jack Lane, my father was a farmer raising flowers. He went peddling in the neighborhood but the income was not sufficient, so he took a job at the Oahu Cemetery as a gravedigger." Later, Kim's father worked at a barbershop and eventually opened an upholstery shop with his wife. John Young-Ahn Kim does not add whether the shop was successful; however, he does tell how from age eleven he sold newspapers and shined shoes to supplement the family income, suggesting that the business was never lucrative. ${ }^{99}$

In addition to urbanization, Korean immigrants increasingly moved from Hawaii to the American mainland. More than one thousand immigrants relocated to the mainland prior to 1919. They concentrated in and around cities like Sacramento, Dinuba and Riverside, California, where work opportunities were more readily available on farms. In cities like Denver, Salt Lake, and Seattle, Korean men worked on railroads or in mining camps while women worked as maids or cooks. As in Hawaii, Koreans often ran small businesses. ${ }^{100}$

In 1919, the Korean population in America no longer had the look of a migrant community. Most Korean immigrants had lived in America at least several years, and many for more than a decade. Families and homes gradually replaced

\footnotetext{
${ }^{99}$ John Young-Ahn Kim, "Coming to Hawai' i" in Passages, 10-12.

${ }^{100}$ Yang, 6. Yang consulted U.S. Census information as well as other information to portray a demographic scene "after 1910." She laments that little information is available because Koreans were not "enumerated separately" in the Census.
} 
bachelor housing, the pursuit of independent careers replaced contract field labor and a sense of permanence characterized the community. ${ }^{101}$

After the 1905 ban on Korean emigration, there were no longer large groups of Koreans coming into America. Individual Korean immigrants (such as picture brides and other who were able to sidestep Japanese barriers) may have experienced culture shock upon first arriving to America, but they had the benefit of settling in communities whose members had long since navigated the foreign territory of American behaviors and beliefs. Indeed, newly arriving Korean immigrants found themselves within established communities that were not only familiar with American worldviews, but had increasingly adopted them as their own. Koreans, especially Christian Koreans, had long been exposed to American concepts of religion and democracy. Fifteen years after Koreans first settled in America, they believed that American values also pertained to Korea. The reaction by Korean immigrants to the 1919 March First Movement demonstrated how Koreans applied American models of liberty and independence to their own struggle against the Japanese colonization of Korea.

\footnotetext{
${ }^{101}$ According to Ronald Takaki, a historian of Asian American history, Korean communities on plantations began to change as immigrant populations stayed longer and had children. After 1909, a unique plantation culture arose as the various nationalities gradually began to socialize in ways they had not before. The sharing of language, for example, became a means for creating commonality among diverse groups. Over time, as people of different nationalities spent more time with each other, they began to speak a pidgin English, incorporating a mixture of English, Chinese, Japanese, Portuguese and Hawaiian. Some plantation workers spoke only their native language and plantation pidgin English, having been exposed to little else. This development was slow and it did not quell immigrants' desire for national solidarity. It demonstrates, however, that immigrants increasingly adopted new practices that differed from those of their homeland. Ronald Takaki, Strangers from a Different Shore: A History of Asian Americans (Back Bay Books, 1998), 167.
} 
The 1919 March First Movement ${ }^{102}$ was the most critical event of the Korean Independence Movement. It began on March first, 1919, when several thousand activists gathered in Seoul's Pagoda Park to declare Korea's independence. A series of demonstrations throughout Korea ensued in the following weeks, inciting harsh retaliations by the Japanese police and armyand leaving Korean-Japanese relations even more acrimonious. The movement ignited Korea's determination for liberty and motivated Korean patriots throughout the following decades. Although distance and time separated Korean immigrants from their homeland, their reaction to the violent and shocking outcome of Korea's March First Movement indicated that immigrants in America remained politically devoted to Korea's independence. The March First Movement did not ultimately lead to independence, but it did rouse Korean patriotic efforts around the globe.

Despite the strict Japanese governance overseeing and restricting Korean affairs, the March First Movement was a thoroughly organized event. Ch'ondogyo, a politically driven group formally called the Tonghak, was the principle force behind the movement. Its main leaders, Yi Sang-jae and Pak Hui-do, were Christian converts who had secretly organized the movement under the guise of Christian church activities, all forms of political gatherings having been forbidden by Japanese authorities. Although the coordinators planned the demonstration for over a year, the sudden death of Korean Emperor Kojong provided them the opportunity to coincide their demonstration with the emperor's funeral. In spite of having lost the esteem of his country with the Japanese takeover, as Korea's last emperor, Kojong remained a

${ }^{102}$ Also commonly known as the March First Uprising. 
nostalgic symbol for Koreans. Aware of this, Japanese officials expected large

crowds to gather for his funeral. They did not expect the masses to quickly transform a grievance ceremony into a highly organized demonstration for Korea's independence. $^{103}$

Hyun Soon, a leading Korea activist and one of the thirty-three signers of Korea's Declaration of Independence, recounted the tumultuous scene shortly after the March First Movement. ${ }^{104}$ Approximately 20,000 people gathered in Seoul's Pagoda Park, music played in the nearby concert hall and "[a]n intense expectation filled the air." 105 As the music concluded, a large Korean flag unfurled from the top of the concert hall while copies of Korea's Declaration of Independence showered over the crowd from above. ${ }^{106}$ Demonstrators passed around thousands of hand sewn Korean flags which had been banned under Japanese rule. ${ }^{107}$ At first Japanese policemen did not react when a solemn occasion turned into an emotionally charged protest for independence. For the moment, they let the crowd proceed.

\footnotetext{
${ }^{103}$ Sucheng Chan, introduction to Quiet Odyssey: A Pioneer Korean Woman in America (Seattle: University of Washington Press, 1990), XXX.

${ }^{104}$ This document contains no exact date as to when Hyun wrote it; however, clues within the text indicate that the he wrote it shortly after March first, 1919, when other independence activities were still taking place throughout Korea. The article is among a collection of Hyun Soon's speeches and essays written in English. There are some minor editing marks suggesting it was a draft, but there is no indication as to where or even if this article was published.

${ }^{105}$ I have not come across any sources that discuss how many of the gathered Koreans were aware that an independence movement was about to take place, for it is probable that some had gathered simply to honor the dead emperor. Yet, according to Hyun's description, it seems that most (if not all) Koreans present expected a demonstration.

${ }^{106}$ A group of Korean patriots composed the Korean Declaration of Independence in 1919. They signed the document on February twenty-eighth, but had already printed and distributed several thousand copies two days prior. Chong-sik Lee, Politics of Korean Nationalism (University of California, Berkley 1963), 110.

${ }^{107}$ Chan, Quiet Odyssey, XXX.
} 
Soon after, Hyun recalled, protestors began marching through the streets in "perfect order." As the procession made its way down Seoul's Union Square it joined other processions that had gathered elsewhere in town. The demonstrators, now numbering around 100,000, sang patriotic songs, chanted "Mansei! Mansei!" ("Long live Korea!"), and stopped to deliver speeches and distribute copies of the Declaration at strategic places throughout the city. Among the stops was the old Legation quarters where foreign officials from America, France, Russia and Britain kept their offices, a tactical point for drawing international attention. Protestors also gathered in front of the Kyeng Pok Palace, Changtuk Palace, and most importantly, the office of the Japanese Governor General where Japanese troops waited. ${ }^{108}$

Japanese officials had no patience for Korean rebels and were perhaps unaware of the protesters' supposedly peaceful intent. They acted quickly and violently to suppress the demonstration, leaving thousands of Korean activists dead or wounded. ${ }^{109}$ According to Kyung Soo Cha, whose sister participated in the March First Movement, the Japanese policemen were not prepared for mass protestors. "In panic they didn't hesitate to use their rifles and swords. Showing no regard for elders and children, they beat and killed those in the crowd right and left." Though a young girl at the time, Cha recalled the violent images she witnessed, “... a person whose ear was bloodied because of a Japanese sword; a person with a gash on his forehead and

\footnotetext{
${ }^{108}$ Hyun Soon “The Independence Movement in Korea.” Digital Archive. East Asian Library, Archival Research Center, University of Southern California, Los Angeles, California. http://digarc.usc.edu/search/controller/view/kada-m732.html.

${ }^{109}$ Chan, Quiet Odyssey, xxxi.
} 
face full of blood; people who carried a dying friend on a stretcher." ${ }^{110}$ Hyun Soon described how "...swords were freely used to slash at the bewildered Korean boys and girls. Those who could not secure fire arms did what they could to do damage to the Koreans with iron hooks and knives and spears.... One of the girls who was hoisting a Korean flag had her arms cut clean off."111

In the following weeks protests continued throughout Korea as did Japanese retaliation. In the town of Suwon, for example, Japanese authorities ordered a group of Korean Christian protesters into a church. They then bolted all the doors and windows and set fire to the building. Those who managed to flee were shot. ${ }^{112}$ Hyun Soon claimed, "To frighten the women they compelled them to take off their clothes after their arrest. Christians were arrested and made to carry heavy wooden crosses, saying they must bear the cross like their savior did."113 Many accounts by Koreans and American Christian missionaries testify to the torture, rape, executions, and general abuse that Koreans suffered during this time. ${ }^{114}$ Protesters claimed that their activities were never meant to be violent yet nearly 16,000 Koreans were wounded

\footnotetext{
${ }^{110}$ Kyung Soo Cha, Pumpkin Flower and Patriotism, trans. Hyun H Kim (Los Angeles, CA., Korean American Education Research Center, 1991), 27-29.

${ }^{111}$ Hyun Soon, "The Independence Movement in Korea."

${ }^{112}$ Sucheng Chan claims that Japanese officials were particularly brutal towards Korean Christians. Quiet Odyssey, xxxi. According to AsianInfo.org., a website providing data concerning the deaths of Koreans involved in the March First Movement, thirty people died in the church that burned in Suwon, Korea.

${ }^{113}$ Hyun Soon, "The Independence Movement in Korea."

${ }^{114}$ Erez Manela, The Wilsonian Moment: Self-Determination and the International Origins of Anticolonial Nationalism (University of Oxford Press, 2007), 199. Manela claims that missionaries at first tried to remain neutral, but the atrocious nature of Japanese retaliations compelled them to notify the American press. According to one report, Japanese forces used "pickaxes, lances, iron bars and hardwood clubs" on Korean protestors.
} 
and about 7,500 killed by Japanese infantry battalions and police troops in the weeks following March first. ${ }^{115}$

The Korean Independence Movement was just one component in a much larger and more complex international movement. After the close of WWI in 1918that is, after the economic failures, the collapse of empires and unspeakable bloodshed — many people around the globe sought grander, more modern ideals on which to rebuild their worlds. With postwar disillusionment came optimistic determination. For colonized countries in particular, the end of war fostered hopes for independence from imperialist powers.

President Woodrow Wilson fueled these hopes when he gave his famous "Fourteen Points" speech to the United States Congress on January eighth, 1818. This speech articulated Wilson's plan for a post war settlement through open trade, transparent international diplomacy and reduced armaments. Point five was of particular interest to colonized nations because it held that "in determining such questions of sovereignty the interests of the populations concerned must have equal weight with the equitable claims of the government." To colonized people, this point seemed to promise them a legitimate vote concerning their own national fate. In his speech, Wilson mentioned specific countries like Belgium and France whose sovereignty and borders he felt should be restored. The focus on European concerns

\footnotetext{
115 AsianInfo.org. "March $1^{\text {st }}$ Independence Struggle". http://www.asianinfo.org/asianinfo/korea/history/march_1st_independence_struggle.htm (accessed 28 March, 2010). Other sources, like Sucheng Chan, claim the records of casualties are vague and vary according to report, but even conservative estimates state that at least several thousand Koreans were killed. No sources I have encountered have claimed that Koreans acted violently in return to the Japanese hostility. Hyun Soon reported that the Koreans were "defenseless" and according to Erez Manela, American missionaries in Korea were distressed by the brutal treatment of Japanese forces against unarmed Koreans. There is the general perception that the violence was one-sided.
} 
did not discourage hopeful Korean activists. With his Fourteen Points, Wilson became the champion of self-determination, a principal on which many rested their visions for a freer and more just world.

Koreans were not the only colonized people who believed that Wilson's speech justified their claims for independence and who hoped to find a supportive audience at the Paris Peace Conference. On January eighteenth, 1919, the yearlong conference commenced in Paris where major leaders gathered with the main objective of rebuilding Europe. The attendance of Arabs, Jews, Armenians, Chinese and Koreans among many other oppressed and stateless peoples of the world, however, guaranteed that the conference was not a strictly Western European affair. Representatives from these various ethnic and national groups arrived in Paris with declarations and petitions for their cause of choice. Wilson paid little attention, claiming that the peace conference was overwhelmed enough with European issues. $^{116}$ Independence movement leaders from Korea, like their counterparts in India and Egypt, intended for the international community to notice their demands for independence. When organizing the March First Movement, Korean independence leaders were astutely aware that their target audience sat in Europe, not Japan. ${ }^{117}$

Korean nationals hoped they would find a sympathetic audience at the Conference but quickly discovered that their presence in Paris was less than welcome. The American government had already acknowledged Japanese annexation of Korea and Secretary of State Robert Lansing did not want Koreans in Paris making things

\footnotetext{
${ }^{116}$ Manela, 5.

${ }^{117}$ Manela, 133.
} 
difficult. Therefore, when Syngman Rhee and Henry Chung, two of the most prestigious Korean activists in America, attempted to secure passports for Paris, the State Department informed them that as Japanese citizens they would have to apply for passports through Japan — a request that Japanese authorities would certainly deny. ${ }^{118}$

One Korean ambassador, Kim Kyusik, made it to Paris by securing a Chinese passport and evading Japanese restrictions. ${ }^{119}$ Kim Kyusik was raised by an American missionary, attended Princeton University and was the foreign minister of the Korean Provisional Government. ${ }^{120}$ He was the ideal candidate to try and appeal to Western powers. To further validate his rightful presence at the conference, the Korean Provisional Government in Shanghai sent Kyushik's official credentials as foreign minister to Paris. They hoped this would secure him a moment with delegates there, specifically Wilson, which it did not. While in Paris, Kim submitted two petitions and attempted unsuccessfully to speak at the conference. ${ }^{121}$ In the end, Kim Kyusik's influence in Paris was of little help to Korea's cause. ${ }^{122}$

Koreans' attempts to gain access to the Paris Peace Conference did not stop there. Korean nationalists in America sent copies of the Korean Declaration of

\footnotetext{
${ }^{118}$ Manela, 201.

${ }^{119}$ Manela, 129.

${ }^{120}$ The Korean Provisional Government was the Korean government in exile, formed in April 1919, in Shanghai, China. Elected officials were made up mostly of leading Korean activists. Syngman Rhee acted as president to the Government. Timothy Savage, "The American Response to the Korean Independence Movement, 1910-1945," Korean Studies 20 (1996): 195.

${ }^{121}$ Lee, 141 .

${ }^{122}$ Manela, 199.
} 
Independence in English to Wilson to state their cause and perhaps instill a sense of duty to the leader of the free world. Syngman Rhee, president in absentia of the Korean Provisional Government, sent a letter to Wilson informing him that Korea had declared itself independent and was now the Republic of Korea. Rhee wrote that he hoped the two countries could continue their friendly relationship. It is doubtful, however, that Wilson ever saw the message for it went directly to the Department of State and was filed under the notation: "Do Not Acknowledge."123 The Paris Peace Conference proved to be a disappointing event for hopeful Koreans when they received little reception and none of the Western support they had hoped for.

According to historian Timothy L. Savage, American policymakers were well aware of the dismal situation in Korea. Yet, prior to World War II, the U.S. government considered Korean interests a subordinate issue to other foreign policy concerns. Government officials ignored Korean appeals for support when they deluged the White House and State Department. Nor did they stir when they received letters from American missionaries in Korea detailing Japanese hostility towards the Koreans during the March First Movement. In fact, the State Department sent a telegram to Tokyo in 1919 cautioning the American Embassy there not to mislead Koreans into believing that the United States would aid the Korean activists. ${ }^{124}$ Amid redrawing European borders and reconstructing precarious relationships among

\footnotetext{
${ }^{123}$ Manela, 200. It is also interesting to note here that Syngman Rhee was a doctoral student at Princeton when Woodrow Wilson was president of the University. Rhee, the first Korean to receive a doctoral degree in America, knew the president personally. Wilson even wrote Rhee a letter of recommendation and was the one to hand Rhee his diploma on graduation day. Rhee most likely hoped that a personal message from an old acquaintance would have some sway with the president. The fact that it did not undoubtedly made the rejection all the more stinging.

${ }^{124}$ Savage, 192-197. Francis Polk sent the telegram to which Savage referred to the American Embassy in Tokyo on the twelfth of April 1919.
} 
the world's super powers, it seemed that American officials considered Korean appeals for support as more of a nuisance than an ideological obligation.

Despite repeated failures, the persistent attempts to gain U.S. governmental support suggest a change in the Korean community at this time. While earlier Korean immigrant communities had been insular, by 1919, Koreans in America had expanded their vision. Their attempts to find an audience at the Paris Peace Conference indicate that their target audience was no longer limited to the Korean immigrant community. Korean efforts to gain recognition did not just occur abroad in Paris and Shanghai, but in the United States as well. By living in America, Koreans knew they had the possibility of garnering the attention (and hopefully, sympathies) of one of the most influential governments in the world.

In 1919, a group of Korean immigrants gathered in San Francisco to call for U.S. intervention in Asia. One photograph in particular captures this event. It shows three men in business suits, hats and long button-up jackets. On a platform behind them stands a group of equally well-dressed children. Most of the children hold protest signs, exclaiming things such as "No Guns to Japan," "Korea Fights for Independence," and "Stop Japan's Murder in Korea and China!" Many of the children hold Korean and U.S. flags. 


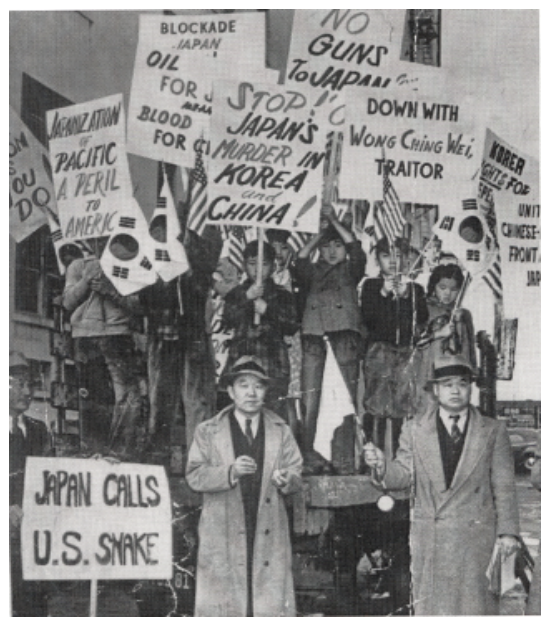

Figure 1: Reprinted with permission of the Korean American Digital Archive, University of Southern California

Photographs are uniquely valuable for the specific information they offerintricate details in the form of background scenes or a fleeting facial expression, for instance. A photograph will invite a series of questions. First, there is the matter concerning time and place. When and where did the photographed event take place, as well as what exactly is in the image? Then, to see more carefully consider what is not in the picture. Who, if anybody, is standing outside of the frame? Who is standing behind the camera and why are they there? There is the important issue of audience. Who was meant to see this photo? And then there are the details. Are they intentional or happenstance? What do they disclose?

In the image above, Korea's independence is the most obvious goal of these protesters. Yet, when one considers the intended audience here, suddenly the photograph reveals more than just Korean contempt for Japanese colonization. Although the archives provide no clear indication as to whether this photograph was shown publicly or remained in private collections, and it is not apparent for whom the photo was taken; we can see whom the protesters were targeting. The inflammatory 
signs about Japan, claiming, "Japanization of Pacific a peril to U.S." and "Japan calls U.S. snake" are clearly meant to rouse American enmity towards Japan. They indicate that the protesters' target audience went beyond the Korean immigrant community to include American policy-makers.

Closely linked to the overt political agendas are subtle social agendas. Sharply dressed men and children, Korean flags, and specific American rhetoric used on their signs broadcast something as well. All advertise legitimacy to the American government that Koreans likely hoped would win them the respect and attention of the American public and government. This photo suggests that Korean immigrants believed that being perceived as Americanized was just as important for their cause as was the recognition of Japanese wrongdoings.

A number of photos show Korean immigrants participating in demonstrations, parades and ceremonies with obvious aims of attracting the attention of the American public. One photo, for example, shows a smiling Korean woman waving cheerfully towards the camera. She wears a sharp pea coat, high heels and hat and is walking in a picket line among other protesters. This photograph depicts more than Korean immigrant patriotism; it advertises their successful assimilation as well. The demonstrators wore American attire (instead of traditional Korean garments, as was sometimes the case) and carried signs written in English to appeal to an American audience and testify to their assimilation.

Photo evidence also shows Korean patriotic events in the years following the March First Movement. One photograph displays a Korean parade in Dinuba, California, where a large Korean population resided. Koreans gathered on the one- 
year anniversary of the March First Movement. Again, the Koreans carried Korean and American flags to suggest to Americans that the Korean Independence Movement was a cooperative effort, ideologically aligned.

What these photos clearly show is the great effort Korean immigrants went to to draw awareness to their cause; what is conspicuously absent is any audience to acknowledge it. Spectators are seemingly absent, or at least too distant to be in the frame, a factor that is symbolically relevant and suggestive. The demonstrators are looking out, but who is returning their gaze?

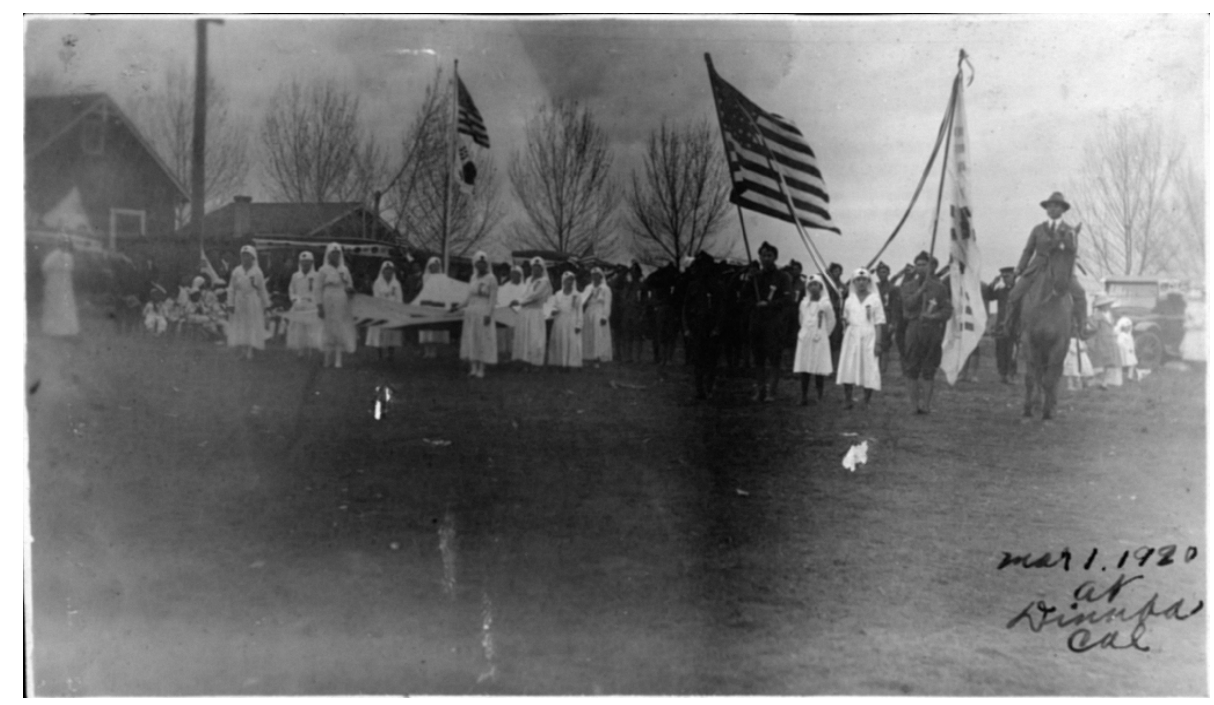

Figure 2: Reprinted with the permission of the Korean American Digital Archive, University of Southern California

Most likely, these gathering were organized by prominent Korean patriotic clubs throughout California and Hawaii whose numbers and zealous resolve grew markedly after the events of 1919. Different factors led to a rise in commitment to the K.I.M. During this time, the Korean National Association increased efforts to bolster propaganda for Korea's cause for independence. In 1919, the KNA began to 
publish the weekly New Korea (Sinhan Minpo) to further spread the club's ambitions for national independence and to increase solidarity among the KNA's chapters in America. ${ }^{125}$ Additionally, some patriotic clubs strove to gather more donations to send to the Korean Provisional Government. Between March 1919 and December 1920, Korean immigrants in America and Mexico raised more than $\$ 200,000$ for the Independence Movement. That equals about thirty dollars per family, or one month's salary. $^{126}$

For most Korean immigrants this was no small sacrifice. Rachel Sung-Sil Kim recalled, "My father gave more than he could afford to the cause. Mother would say that the children needed food and that father was taking food away from us and giving it to Rhee. He answered by saying we would survive, but that Korea had to have independence."127 As a child Eun-Ai Cho had negative memories associated with the K.I.M. She remembered, "I was also very angry because I could not get a pair of Chinese black velvet shoes with pretty flowers and birds embroidered on them. Ever since that day, Syngman Rhee had been my enemy because he kept taking away all of our extra money. We didn't have much money."128

\footnotetext{
${ }^{125}$ Chan, Quiet Odyssey, xlviii.

${ }^{126}$ Alice Yang Murray, "Ilse Women and the Early Korean American Community: Redefining Origins of Feminist Empowerment," in Unequal Sisters: a Multicultural Reader in U.S. Women's History. ed. Vicki Ruiz and Ellen Carol Dubois (New York, Rutledge, 2000), 208.

${ }^{127}$ Rachel Sung-Sil Kim, "What Have We Done,” 99.

${ }^{128}$ Eun-Ai Cho "A Follower of Dr Rhee" Passages to Paradise: Early Korean Immigrant Narratives from Hawaii, ed. Daisy Chun Rhodes (Los Angeles, CA: Academia Koreana, Keimyang University Press, 1998), 20.
} 
In some cases, new clubs formed in response to the March First Movement. Park Yong-man founded the Korean Independence Corps (Toknip-dan) to support an independence army. It is unclear whether Park organized this club with the hopes of recruiting soldiers for the cause or whether he wished only to raise funds for a military defense. ${ }^{129}$ In any case, he supported an aggressive military course of action against the Japanese unlike Ahn Chang-ho who hoped to slowly cultivate a generation of upstanding, educated Koreans who could successfully lead an independent Korea. Prior to forming the Korean Independence Corps, Park had founded a Korean Youth Military Academy in Nebraska and subsequent academies throughout California, Kansas and Wyoming where he trained cadets. In 1912, Park combined these groups to form the Hawaiian-based Korean National Brigade of more than 300 members. ${ }^{130}$ Although Park had long focused on a military approach to dealing with Japan, it was the 1919 events that galvanized his efforts.

Women's patriotic clubs also became increasingly active and influential in response to the March First Movement. Historian Eun Sik Yang even claims that 1919 marked a change in women's contributions from being supplemental to essential. ${ }^{131}$ Two women's groups became particularly prominent-the Korean Women's Patriotic Society in California and the Korean Women's Relief Society of

\footnotetext{
${ }^{129}$ Chan reports that two months after Park formed the Korean Independence Corps he left his cadets behind to move to Shanghai and then to Manchuria to train Korean exiles. Although she does not specify, it is unlikely that Koreans in the United States would relocate to Asia in order to serve in a rebel army, choosing instead to support the cause through monetary contributions. Chan, Quiet Odyssey, liii.

${ }^{130}$ Chan, Quiet Odyssey, lii.

${ }^{131}$ Yang, 12.
} 
Hawaii. Both groups formed after the March First Movement by consolidating women's patriotic clubs in their area. The group members' central goals were instilling patriotism, increasing fundraising and boycotting Japanese goods. ${ }^{132}$ They sent donations to the provisional government in Shanghai and the Korean Independence Army. On several occasions in 1919, Korean women assembled to protest the annexation of Korea. On March fifteenth, just two weeks after the March First Movement, members of the Korean Women's Relief Society in Honolulu dressed in traditional clothing and marched through town singing patriotic songs. To make extra money they sold copies of the Korean Declaration of Independence as well as Korean food, like kimchi and rice cakes. ${ }^{133}$ In August of 1919, a group of Korean women presented a dramatic performance, "The Tragedy of Korea” and raised nearly four hundred dollars for the cause. ${ }^{134}$

Such activities illustrate the importance of women to the Korean Independence Movement and demonstrate that, by 1919, Korean women were able and eager to be politically active in the public sphere. By participating in gendersegregated patriotic societies, Korean women acted autonomously and made decisions independently of men. Women's patriotic clubs did not operate in complete separation from men's patriotic groups. Women's groups remained closely aligned with men's groups for two main reasons. First, women's societies remained 'under the umbrella" of the KNA. Although they designated their own female leaders,

\footnotetext{
${ }^{132}$ Yang, 15.

${ }^{133}$ Chan, Quiet Odyssey, lviii; Murray, 208.

${ }^{134}$ Yang, 17.
} 
women's groups, like the Korean Women's Patriotic Society, adhered to the principals of Ahn Chang Ho, the founder of the KNA, sharing the same ideological figurehead as the most prominent activist club among Korean men in America.

Money was the second reason women and men's groups worked together. Men were interested in the activities of women's groups because, by 1919, Korean women were more effective at raising funds for the K.I.M. Therefore, men did not refrain from advising women on how to donate their money. For example, in 1921, the KNA did not want to send money to support Phillip Jaisohn's Korean Commission. ${ }^{135}$ Initially the Women's Patriotic Society considered sending a donation but members of the KNA "recommended strongly" against it, so in the end their donation was minimal. ${ }^{136}$ The success of these women's groups presented a catch-twenty-two: it demonstrated women could work effectively independent of men, but their very success ensured that men attempted to influence their decisions.

The Movement declined from 1924 to 1936; however, some of these clubs remained active even when the resistance movement itself waned. Women still participated in these clubs by providing social services to orphanages, schools and needy Koreans. In periods of weakened political zeal some of the women's societies refocused their energies on women's rights, calling for women to "Stand up and unshackle our next generation from [traditional] constraints." By 1919 and the years following, Korean women's societies looked increasingly feminist, concentrating

\footnotetext{
${ }^{135}$ The Korean Commission was a small group of Korean immigrants and Korean Americans, including Philip Jaisohn and Henry Chung, who worked in Washington D.C. to raise awareness about Korea's movement for Independence and to establish reliable communication with the Korean Provisional Government in Shanghai. Interview with Henry Chung, 63.

${ }^{136}$ Jaisohn requested extra funds to present a petition at the Washington Disarmament Conference. It is unclear why the KNA denied Jaisohn's request. Yang, 18.
} 
more on women's roles outside of the home. Historian Alice Yang Murray claims that Korean women's patriotic clubs did not intentionally set out to expand women's roles or challenge patriarchal systems. Murray argues that patriotic efforts, such as controlling family spending and emphasizing Korean traditions and customs in child rearing, reinforced traditional gender roles by emphasizing women's position in the home. This is maybe true, particularly in the earliest years of immigration. Yet, in the years shortly following the 1919 March First Movement, Korean women's clubs had stated feminist purposes, to accumulate wealth, receive an education and to free themselves from "bondage." 137 They had evolved to encompass specific progressive aims of breaking past "traditional constraints," suggesting a connection between their political participation in the K.I.M. and feminist aspirations. ${ }^{138}$

After the March First Movement, Koreans in America strove to demonstrate that they had embraced American ideals of liberty, Christianity and patriotism. No single event articulates this more clearly than the 1919 Korean Congress in Philadelphia. For three days in April, a committee of nearly 200 Korean delegates gathered to discuss Korean independence and listen to inspirational speeches by leading Korean activists. A small booklet published by the Korean Congress shortly

\footnotetext{
${ }^{137}$ Yang, 20. Quotes taken from the Korean publication, Shinhan Minbo, on May 26, 1921.

${ }^{138}$ Participation in women's clubs has a connection with other American women's groups that advocated Progressive Era ideals. At this time thousands of other women's groups throughout America expanded established gender roles by working for social causes, such as poverty, public health, the environment, education as well as political issues. Some of the more prominent Progressive Era women's groups include the Daughters of the American Revolution, the Christian Women's Temperance Movement and the Young Women's Christian Association. There were also many women's groups that were ethnicity specific, like the National League for the Protection of Colored Women or the National Council of Jewish Women. Korean women's groups, though not purposely progressive, corresponded with a much larger women's movement in America. They not only adopted American ideals, they adopted gender-specific ideals as well.
} 
after the close of the meeting provides the conference minutes, including the complete speeches, which exemplify Korean ideals and patriotism.

The committee included some of the most prominent Korean American figures like Syngman Rhee, a graduate of Harvard and Princeton University, and Philip Jaisohn, the first naturalized Korean American. On the first day, the president of the committee, Jaisohn, stressed Korea's absolute right to liberty and spelled out the goals of the conference. Their first objective was to compose a message for the Korean Provisional Government in Shanghai offering wholehearted support and gratitude for its efforts. Thereafter the delegates agreed to draw up committees that would draft and deliver resolutions for self-determination to be distributed to the American Congress and public to inform them of Korea's plight as well as to appeal for support in their endeavors for independence. The committee also agreed to send a straightforward and "Christianlike" message to the Japanese people outlining the wrongs their government had committed against Korean citizens and to inform them of Korea's intent to fight for independence. In those three days, the Korean Independence leaders outlined their goals for the Korean Independence Movement more clearly and cooperatively than they ever had before.

Despite the emphasis on Korean independence, the assembly procedures scrupulously mimicked standard American protocol. During the opening ceremony delegates rose and sang America's national anthem. Throughout the conference all measures emulated American democratic patterns through careful, if not exaggerated, voting systems. In a closing ceremony, participants formed a parade and marched from the Little Theater to Independence Hall, waving both Korean and American 
flags. In front of the very building where American delegates signed the American Declaration of Independence in 1776, Rhee read aloud the Korean Declaration of Independence. According to the printed Korean Congress booklet, "After the reading of the Korean Declaration of Independence, the delegates formed in line and as each man passed the Liberty Bell he touched it with his right hand," one of the several ways in which the Congress symbolically linked American idealism and history to Korea's struggle for independence.

Throughout the conference Jaisohn, Rhee and several other guest speakers took obvious measures to deliver speeches that would confirm Korean immigrant acculturation to any American onlookers. First, all speeches were given in English. Speaking Korean was not prohibited; yet, according to the Congress minutes, most discourse took place in English. At first this would not seem the obvious choice, for certainly Korean was the stronger language of most delegates. The booklet offers no explanation as to why the conference was held in English. However, one can infer that they hoped to gather the attention of an English-speaking audience. Perhaps by speaking English they could better prove to Americans how well Korean immigrants had integrated. In fact, during one speech, Philip Jaisohn alludes to successful Korean integration, saying:

You have heard objections to Japanese and Chinese immigration, but you have never heard objections to Korean immigration. The Japanese build their hideous temples everywhere in Hawaii. They carry Japan into Hawaii and into America. They want to establish a little Japan wherever they settle. You Americans do not want that class. If a man comes into this country to make his living, he intends to live here, and if he does not become a part and parcel or an integral part of that community you do not want him. ${ }^{139}$

${ }^{139}$ Korean Congress. Committee print. 16. 
Jaisohn not only attempted to sway opinion against Japanese immigrants, he insinuated that despite being legal citizens of Japan, Korean immigrants were not like the Japanese; they are the ones striving to be "part and parcel" of American society.

Korean women also participated in the congress. The congress did not nominate any women to high leadership positions; however, they did elect Nodie Dora Kim to the committee to help draw up an appeal to Japanese people. She also gave a noteworthy speech to the Congress regarding Korean women's position in the K.I.M. After Syngman Rhee introduced Kim as a "champion of her sex," she spoke of women's social progress and achievements in recent decades. She described a past in which women in Korea were treated as inferior to men and left out of political and social work. Kim claimed that, having taken lessons from France and America, Korean men had begun to see women as equals. Korean women, likewise, took lessons from the Western world. According to Kim:

[W]hen the [American] boys went to France the women did the work at home. The girls went into the munitions factories, they became conductors on the streetcars and they showed intelligence and capability in the highest positions. So we, the Korean women, are co-operating with the men of Korea and are trying to help in securing her independence and liberty. ${ }^{140}$

There are two important aspects to Kim's speech. First, she praised the efforts of Korean women in the fight for Korea's independence. Hers, and the comments preceding and following her speech, suggest that Korean men and women alike honored the contributions of women. But the proceedings of the Congress did not always exemplify the meeting's rhetoric of equality. Korean women did not have an equal voice and were not given equal say or influence compared to their male

${ }^{140}$ Korean Congress, 17. 
counterparts in the Congress. Although Syngman Rhee claimed that "several ladies from Korea" were present, the only Korean woman mentioned by name was Nodie Dora Kim. That women were present at the congress and their financial contributions to the K.I.M. were equal or more to those of Korean men, does not mean they had equal representation, an obvious discrepancy between idealism and reality.

The second important aspect of Kim's speech is the connections she made between American and Korean struggles for women's rights. Nodie Dora Kim flattered Westerner's sensibilities by referring to America as a model for women's advancement. Although her speech addressed Korean women's progress in particular, by incorporating references to France and America, Nodie Dora Kim, much like Philip Jaisohn, referred to the successful acculturation of Koreans as whole to a Western model.

During the conference, patriot leaders confirmed that their commitment to Korea's independence did not threaten their loyalty to America. Philip Jaisohn was the most prevalent speaker at the event and an appropriate figure to disseminate this message. Having received his education in American universities and as the first Korean to become a U.S. citizen, Jaisohn was the quintessential Korean American. Upon being nominated for President of the Korean Congress he declared that as a naturalized citizen his loyalties were with America. Although he supported Korean independence, he stated that, "if there should be any occasion... which in the slightest degree would be in conflict with the interests of the United States or the laws of the United States I will step out." This was a sentiment that Syngman Rhee supported by 
responding that no man was welcome who was not "above all, 100 percent loyal American."141

This overt loyalty towards America may have been a preemptive attempt to deflect any accusations of untrustworthiness from the wider American public. Koreans certainly recognized that white Americans were particularly distrustful of foreign-born communities during the World War I era. Even European immigrants, such as Irish, French and Germans, felt they must prove their loyalty towards the American government by purchasing Liberty Bonds, organizing relief funds or speaking English. Asians remained particularly suspicious, many Americans believed, because they could not become naturalized citizens and presumably never fully assimilated. ${ }^{142}$ Therefore, any overt expression of Korean patriotism could cast a negative shadow on the Korean community. Aware of this, members of the Korean Congress repeatedly expressed their allegiance to the United States.

On the first day of the conference, Jaisohn articulated the notion of dual allegiances, saying, "There is no nation in the world whom the Koreans love more than the United States of America, excepting only their own country." Jaisohn, criticized countries that entered Korea in order to gain territory, wealth or political influence, contrasting the United States which entered Korea with altruistic motives.

America sent missionaries by hundreds, they brought the bible with which they gave this oppressed and unfortunate people a new hope and a new courage in this life. The Evangelical efforts of these missionaries were

\footnotetext{
${ }^{141}$ Korean Congress, 8.

${ }^{142}$ Elliot Robert Barkan, From All Points: America's Immigrant West, 1870s-1952. (Indianapolis: Indiana University Press, 2007), 194-208.
} 
followed by hospitals, schools, science, arts, music and the spirit of independence and democracy. ${ }^{143}$

As in public demonstrations where participants dressed in modern Western attire and carried English language signs to solicit American sympathies, Congress delegates asserted Korean nationalism by coupling it with American patriotism. Jaisohn's statement was not only particularly flattering to the United States, it employed the catch phrases of American idealism, "independence" and "democracy." While countries in other parts of the world may oppose an American presence, Jaisohn thanked America for its religious and political indoctrination of Korea.

Later in the afternoon session of the first day, Syngman Rhee read aloud the "Appeal to America." The plea summarized Japanese transgressions against the Koreans, comparing Japanese colonialism to the 1914 German invasion of Belgium. After a short introduction, the writers of the Appeal claimed Korean independence could be justified based on historical precedents:

For four thousand years our country enjoyed an absolute autonomy. We have our own history, our own language, our own literature and our own civilization. We have made treaties with the leading nations all over the World; all of them recognized our independence, including Japan...Ever since she has been ruling Korea with that autocratic militarism whose prototype has been well illustrated by Germany in Belgium and Northern France.

Rhee then recapitulated the Japanese takeover of Korea and the ruthless authority under which Koreans had "patiently suffered." He provided reasons why the United States should support Korea's cause for independence:

We appeal to you for your support and sympathy because we know you love justice; you also fought for liberty and democracy, and you stand for Christianity and humanity. Our cause is a just one before the laws of God and

${ }^{143}$ Korean Congress, 4. 
man. Our aim is freedom from militaristic autocracy; our object is democracy for Asia; our hope is universal Christianity. Therefore we feel that our appeal merits your consideration.

You have already championed the cause of the oppressed and held out your helping hand to the weak of the earth's races. Your nation is the Hope of Mankind, so we come to you.

The statement appealed to the United States' moral obligation to support Korea and its political obligations under the terms of the 1882 treaty whereupon both countries had agreed to support the other if foreign powers dealt unjustly or oppressively with either government. The appeal referred to the principals formulated by Woodrow Wilson at the Paris Peace conference where he claimed "it is the friendly right of every nation a member of the League to call attention to anything that she thinks will disturb the peace of the world, no matter where that thing is occurring."144 Korean nationalists may have had little clout in Paris, but Korean American citizens like Phillip Jaisohn, likely hoped they could generate more influence by capitalizing on their residence in the United States.

The American public and government did not rise to their obligations as stated by the Korean Congress. Nevertheless, Korean efforts did not go completely overlooked. On the third day of the Congress, a local Philadelphia newspaper printed a short column covering the event and reporting on the Korean plight. The last paragraph of the article stated, "Korea is entitled to its independence, and we hope it will get it. It will find a world now more responsive to its appeals than when its delegates knocked in vain at the White House door a dozen years ago." ${ }^{145}$ In

\footnotetext{
${ }^{144}$ Korean Congress, 30.

${ }^{145}$ Korean Congress, 75. Author and name of newspaper not provided.
} 
addition, a few American congressmen even advocated for Korea's cause on Capital Hill. Seldon Spencer of Missouri submitted a resolution on June thirtieth, 1919 to persuade the secretary of state to reconsider supporting Korea through terms of the 1882 treaty. Nebraska's George Norris presented a speech to the senate on August fifth of the same year claiming the need to assist Korea's struggle for independence. ${ }^{146}$ It is plausible that expanding Japanese imperialism, and not the preservation of Korean national identity, compelled this support, but at the very least, the wishes of Korean nationalists converged with U.S. desire to curtail Japanese expansion. Ultimately, the Korean Congress did not rouse tremendous support from the American government nor its public and Korean immigrants were left to go it alone.

The lack of U.S. political support for Korean independence begs the following question: Why did Korean immigrants feel a deepening reverence for America, so much that they wished to replicate American institutions in the construction of a postcolonized Korea? Economic and political incentives motivated Korean immigrants to establish families and businesses, thus altering the demographic appearance of the Korean community in America. The rising sense of loyalty towards America may also be a reflection of this demographic shift. By 1919, most Koreans had spent more than a decade in America, and as the population of American-born Koreans increased, so did their patriotism. Additionally, the shift of population from Hawaii to the continental United States may have made Koreans feel closer to the American mainstream (in comparison to the more secluded ethnic enclaves of Hawaii), and

\footnotetext{
${ }^{146}$ Savage, 196.
} 
therefore more familiar with American traditions and cultural customs. In other words, after fifteen years, Koreans felt more at home in their host country and were more inclined to seek acceptance there.

Chapter one discussed how Koreans used Korean nationalism/patriotism as a means to build ethnic communities in America, to ease their homesickness and to distract them from the drudgery of plantation life and poverty. In the decades following 1905, immigrants used the same nationalist organizations to connect with their American neighbors. An extended conversation on community is applicable here if one considers how Koreans were trying to incorporate their immigrant community into the larger American national community. Benedict Anderson states that a nation is imagined because "regardless of the actual inequality and exploitation that may prevail in each, the nation is always conceived as a deep, horizontal comradeship." ${ }^{147}$ We see attempts to articulate Korean immigrant relations as a "deep, horizontal comradeship" during the Korean Congress when Syngman Rhee claimed, “...the aims and aspirations of the Korean people are identical with those of the president of the United States in seeking to form with our allies a League of Nations."148 Jaisohn brought up similar connections when he said, “...we know you [Americans] love justice, you also fought for liberty and democracy and stand for Christianity and humanity...our object is democracy for Asia; our hope is universal

\footnotetext{
${ }^{147}$ Benedict Anderson, Imagined Communities: Reflections of the Origins and Spread of Nationalism (New York: Verso, 2006), 7.

${ }^{148}$ Korean Congress, 8 .
} 
Christianity." 149 Few, if any other Asian nations, would make such a bold claim, and yet in doing so, Jaisohn's words linked America, Korea and Korean Americans through shared ideological rhetoric.

As the Korean Independence Movement activists increasingly looked to America for assistance, Korean immigrants depicted themselves on the same trajectory as other Americans. Although most Korean immigrants and most Americans did not know each other personally, Korean immigrants could conceive through historical means that the lives were indeed parallel by alluding to a connected history and shared goals.

The Korean Congress speeches and efforts at the Paris Peace Conference provide glimpses into how Korean immigrant nationalists gradually acculturated and how they used their patriotic cause to do so. By 1919, Koreans in the United States had families, homes and businesses; they had incorporated to their lives cultural elements that were foreign to Korea and unique to America. But Koreans still resided in limbo. In America, they were neither American nor Korean. The whole world told them they were Japanese, which they most certainly were not. Their homeland which most of them left between 1903 and 1905, no longer existed as they knew it. They must have asked themselves where they belonged, perhaps answering: if not Korea, then here, in their host country, America, a land they learned to admire and honor. The patriotic activities of 1919 reveal not only a call for international assistance and recognition, but a desire for place — that is, a place they could understand and feel connected to.

${ }^{149}$ Korean Congress, 30. 
"This is the beginning of our New Day.

A great task is before us." 150

Syngman Rhee

\section{Chapter Three \\ 1945 and the Liberation of Korea: \\ From "Enemy Alien" to Korean-American}

The years from 1941 to 1945 designate the last period of fervent activism during the Korean Independence Movement as well as its closing. The characteristics of Korean activism in America changed between the World War I era to that of World War II. In the 1920s and 1930s, public demonstrations, fundraising and patriotic club activities declined. Although Korean activists did not cease their efforts entirely, the K.I.M. entered a near dormant phase. Korean patriots in America lost much of their energy until 1940 when the looming threat of a Japanese attack against America galvanized them. In 1941, the United States declared war on Japan.

Koreans in America rejoiced that after decades of appeals, the American government would confront Japanese powers. Some Korean immigrants took this as a sign that the American government was offering them more than just "unofficial sympathy" and was finally fighting for Korean independence. World War II ended with the defeat of Japan and after forty years of struggle against its colonizers, Korea at long last gained independence from Japan.

This chapter focuses on two periods. The first spans from 1922 to the late 1930s, a period of significant decline in Korean nationalist activities. The second period is from the late 1930s to 1945, with the closing of World War II and the end of

\footnotetext{
${ }^{150}$ Syngman Rhee, Washington D.C., open letter to fellow Koreans, 11, February, 1942, Special Collections, East Asian Library digital archive, University of Southern California Los Angeles. http://digarc.usc.edu:8089/cispubsearch/jpgview.jsp?object_name=kada-m7931\&ORN.
} 
the Korean Independence Movement. Korean patriot activities suggest that by the 1920s and 1930s, the American Korean population was a community that no longer needed an overseas nationalist movement to politically and ideologically connect them to their homeland and to one another. Furthermore, their participation in the American army during World War II and their ideological distancing from Korean activists in Asia indicate that Korean Americans, though still anxious for Korean independence, fought against the Japanese as Americans.

According to historian Chong-sik Lee, "The comparatively peaceful and orderly years between 1921 and 1930 in Korea were the worst period of slump for the Korean nationalists abroad."151 Lee claimed that Koreans released their pent-up frustrations during the 1919 March First Movement, after which they "simmered down." Moreover, the post-March First Movement reforms introduced by Japanese officials effectively decreased tensions in Korea. ${ }^{152}$ Meanwhile, discord within the Korean Provisional Government and among organizers of the Korean Independence Movement disrupted any chance for activists to successfully campaign for Korean independence or to keep patriotism high. ${ }^{153}$

Opposition to Japanese forces persevered in Korea and China, albeit with much less fervor than in the years from 1919-1921. In the 1930s, Japan faced many political and economic hardships which consequently spurred an increase in Korean

\footnotetext{
${ }^{151}$ Chong-sik Lee, Politics of Korean Nationalism (Berkley: University of California, 1963), 156.

${ }^{152}$ Lee explains that after the 1919 March First Movement, Japanese rule in Korea became significantly more lenient. Koreans could again publish Korean newspapers, form organizations and hold meetings. 227.

${ }^{153}$ Lee, 167.
} 
nationalist activities. The worldwide economic depression seeped into Japan leaving small business owners and farmers struggling. According to Lee, the Japanese government and military faced many serious disagreements, including attempted coups. $^{154}$

These overlying issues weakened Japanese authority, but it was the Manchurian Incident that was pivotal in refreshing the Korean Independence Movement. In September 1931, Japanese troops invaded Manchuria after a group of Chinese dissidents supposedly bombed a section of Japanese railroad in the area. Koreans in China saw an opportunity to capitalize on the hostilities between China and Japan. A terrorist group supported by the Korean Provisional Government and financially supported by Koreans in Hawaii staged two attacks. The first incident took place in Tokyo in January, 1932, when a Korean man, Yi Pong-ch'ang threw a hand grenade at a royal procession as a failed attempt to assassinate the Japanese emperor. Yi only managed to wound two horses in the procession, but he was able to stir up excitement in China where anti-Japanese sentiment ran high and Korean dissenters resided.

The second incident occurred in Shanghai on April twenty-ninth, 1932. Yun Pong-gil threw a bomb into a group of Japanese dignitaries gathering for a celebration in Shanghai's Hungk'ou Park. The bomb injured many and left two dead. The Chinese government offered their condolences to the Japanese and then proceeded to supply the leading organizer, $\mathrm{Kim} \mathrm{Ku}$, with material support as well as helping him escape arrest. Kim Ku continued to lead the movement in China and received

${ }^{154}$ Chong-sik Lee, 180-181. 
funding from the Chinese. The Chinese army and air force even cooperated with $\mathrm{Ku}$ to set up a special unit to train Korean officers for the Korean Independence Movement. Unfortunately, the officer training did not amount to much. Funding dwindled within a few years and the Korean Independence Movement in China weakened due to factional strife. ${ }^{155}$

Korean activism in America tapered during the 1920s and 1930s. Koreans were less vocal about Korean independence and they contributed less money to fund the movement. According to Hyung-chan Kim and Wayne Patterson, Korean immigrants made fewer donations between 1925 and 1936. Most of the donations Korean clubs collected were sent to victims of Korean flood and famine and did not total more than a couple thousand dollars. Koreans apparently funded the previously mentioned terrorist activities, but the total amount was only $\$ 1,000$ and came from a single group, the United Society of Kauai, rather than through a nation-wide effort. ${ }^{156}$ This is a stark difference from 1919, when Korean immigrants collected more than $\$ 200,000$ in less than two years. ${ }^{157}$

The Depression contributed to the decline in Korean patriotic efforts. Fewer and smaller monetary donations meant that Korean clubs suffered financially during

\footnotetext{
${ }^{155}$ Chong-sik Lee, 184-188.

${ }^{156}$ Hyung-chan Kim and Wayne Patterson, The Koreans in Hawaii 1882-1974: A Chronology \& Fact Book (New York: Oceana Publications, 1974), 40. This book provides a long, thorough timeline of events relevant to Korean American history from 1882 to 1974. It does not provide a narrative history of this time period; instead it lists short points, such as when Koreans founded a new patriotic club or Korean church, when key political events took place or the dates of significant accomplishments of prominent Koreans in America.

${ }^{157}$ Figure taken from Alice Yang Murray, "Ilse Women and the Early Korean Community: Redefining Origins of Feminist Empowerment" in Unequal Sisters: a Multicultural Reader in U.S. Women's History. ed. Vicki Ruiz and Ellen Carol Dubois (New York: Rutledge, 2000), 208.
} 
these years. For example, the Mutual Relief Society reported having $\$ 3,940$ in its savings account in 1928. In 1931, dire finances forced the group to consider whether the society should remain active. The majority voted for the club to continue, however, in 1934, records showed that they were not fairing any better, with only $\$ 1,926$ in their savings account. The Mutual Relief Society merged with the Korean National Association in $1937 .^{158}$

Korean patriotic leaders had not fully retired, but they too achieved little during this stagnant period. Syngman Rhee made the most noteworthy attempt to gather international attention for Korea's cause in 1932 when he traveled to Geneva and Vienna to present Korea's case for independence before the League of Nations. Predictably, Rhee made little headway. In fact, according to Timothy L. Savage, Rhee made a negative impression on American Consul Prentiss B. Gilbert, who criticized Rhee for his "vagueness" and "uncertainty."159 Although members of the League objected to Japanese military expansion, Korea's case remained a minor issue. $^{160}$

Koreans in America may have had fewer events to sustain their energy, yet throughout the 1920s and 1930s, even newsworthy events failed to provoke patriotic

\footnotetext{
${ }^{158}$ Kim and Patterson, 39-43. It is unclear what initiated the merge. The Mutual Relief Society may not have been able to support itself financially or it may have been part of an effort to create a more unified, cohesive movement starting in the late 1930s.

${ }^{159}$ Timothy L. Savage, "The American Response to the Korean Independence Movement, 1910-1945" Korean Studies 20 (1996): 206.

${ }^{160}$ Bong-youn Choy Koreans in America (Chicago: Nelson-Hall, 1979), 168. Rhee met similar disinterest on his return trip to America when he stopped in Moscow hoping to discuss Korean independence with Russian diplomats. No authorities were willing to meet with Rhee and he left the following day.
} 
enthusiasm. For example, in 1929, students in Korea organized a peaceful demonstration protesting the unequal education system, claiming that Japanese authorities treated Koreans as inferiors. As in the March First Uprising, Japanese police responded violently to the non-violent protestors. Nonetheless, Koreans in America apparently did not respond much other than to send their moral support along with their small financial contribution. ${ }^{161}$

In general, both first and second-hand accounts are quiet regarding Korean Independence Movement activities in America in the 1920s and 1930s. In combing through dozens of early Korean immigrant accounts, I discovered several reoccurring themes, such as early camp life, Christianity, discrimination and World War II. The Great Depression was not among these common themes. Mary Paik Lee, whose memoir thoroughly integrated relevant historical events into her life story, simply mentioned, "the great depression in the early 1930s wiped out most of our savings..." Lee and her husband felt compelled to sell their produce business, adding only, "We certainly hated to give up such a good business, but in a way we were relieved. Both of us were very tired and the loss of our savings had made us feel pretty low." ${ }^{162}$ Her discussion of these years was brief and not coupled with any mention of patriotic activities. Koreans in America did not dwell on this period, suggesting that independence did not take the forefront of the Korean community's energy.

That few Korean immigrant narratives speak of the Depression years does not mean the memories are not there. It may be that these years were too painful to

\footnotetext{
${ }^{161}$ Choy, Koreans in America, 167.

${ }^{162}$ Mary Paik Lee, Quiet Odyssey: A Pioneer Korean Woman in America, ed. Sucheng Chan (Seattle: University of Washington Press, 1990), 84.
} 
recount. It could also be that those years did not seem worth recounting. So often personal stories hinge on the current events that punctuate them. When the K.I.M. receded for a decade and half, perhaps a report on the toilsome humdrum of struggle and poverty at this time seemed less exciting or informative. When the Korean Independence Movement receded, so did Korean immigrant stories. Historians who address the Korean Independence Movement mimic this quietness. Bong-youn Choy, who provides a thorough record of Korean patriot involvement preceding and during the World War II, reports little on this time. Choy dedicates only a single paragraph to the student uprising in 1929 , and made no mention of Korean immigrant pleas to affluent governments on the students' behalf. No first hand accounts I have encountered mention the incident. There is apparent agreement among Korean immigrants and their interviewers and the historians who wrote about the Korean nationalist activities that the K.I.M. dwindled in the post World War I and the pre World War II years.

The two major fronts in the Korean Independence Movement, one in Asia, the other in America, were symbiotically connected. Korean activists in Asia protested against the Japanese through direct confrontation, such as during the 1919 March First Movement and through overt acts of violence in the 1930s. Koreans in America protested on behalf of Korea and supported the Korean Provisional Government in Shanghai monetarily. For the K.I.M. to persevere, Koreans in America needed to feel inspired enough by patriotic efforts in Asia to send donations. Meanwhile, the Korean Provisional Government required donations to organize resistance activities. Neither front acted independently. After the March First Movement, no event in the 
1920s or 1930s stirred Korean immigrant passion, nor did the Korean Provisional Government have sufficient funds to operate effectively.

The lack of inspiring international political events in the 1920s and 1930s also failed to motivate Korean patriots. In 1905, Koreans responded to the occupation of Korea by Japan, and in 1910 to the official takeover of Korea. In 1919, they responded to the closing of World War I and the Paris Peace Conference by intensifying their activism. In the two decades between the world wars when Japan sat relatively still and the world's super powers spent less energy restructuring national boundaries and political systems, there were too few political events to spark the Korean activist fire.

Political divisions among Korean independence organizations also served to weaken the K.I.M. in these two decades. Ideological differences created disunity among Korean independence leaders in America and China. While Koreans in China increasingly associated with communist activists and proposed direct and aggressive action against the Japanese, the more conservative leaders in America maintained that having alliances with powerful democratic nations was the most effective course of action. ${ }^{163}$ In America, political strife within and among Korean patriotic clubs prevented a unified movement before the late 1930s. Disputes among K.I.M. leaders were ceaseless. Philip Jaisohn and Henry Chung accused the acting chairman of the Provisional Government, Hyun Soon, of embezzling \$1,500 from Commission funds in 1921. Upon learning this, President Syngman Rhee quickly relieved Soon of his position. Rhee faced his own troubles in 1925 when thirteen members of the

${ }^{163}$ Choy, Koreans in America, 168. 
Provisional Government tried to impeach him. Although a five-member board found Rhee guilty of breaking the Provisional Government's constitution, he and his supporters resisted impeachment, claiming the charges were illegal. Rhee remained president of the dormant Provisional Government partly because he had many supporters in Hawaii who were major monetary contributors. ${ }^{164}$

The maturation of second generation Koreans also contributed to the decline of independence activities before World War II. Children of Korean immigrants had not lived to witnessed the downfall of Korea's last emperor, had never watched as Japanese soldiers invaded streets and homes, had never been forced to speak Japanese instead of Korean. Simply put, they had never known an independent Korea. While their parents fought for relatives and friends, children of immigrants fought for people they had never known, whose pictures they may have never seen. Additionally, most second generation Korean immigrants did not share their parents' sojourner mentality. Many immigrants cling to the hope that they will someday return to their homeland. For Koreans in the United States and Hawaii, this hope most certainly fueled their desire to support the Korean Independence Movement, for until the Japanese left Korea, returning home was a highly unfavorable prospect. Having spent their lives in Hawaii and the United States, some second generation Koreans had a different understanding of Korean independence and their roles in helping to achieve it than their parents.

Most Korean immigrants arrived in America before 1910 with their American born children maturing by the 1920 s and 1930 s so Americanization and acculturation

\footnotetext{
${ }^{164}$ Chong-sik Lee, 167-173.
} 
characterized the Korean community in this period. There are different ways to gauge this gradual shift from Korean immigrant to Korean American. One study found that up to fifty percent of Korean picture brides used their American given names throughout their lives, a higher rate than the earliest Korean women immigrant according to the study. Another study used Korean immigrants' relatively high rates of English fluency to measure American acculturation. ${ }^{165}$

One prevalent theme in Korean immigrant narratives is the higher tolerance second generation Koreans adopted towards Japanese, especially Japanese immigrants. According to second generation Koreans in America, earlier Korean immigrants expressed far more disdain toward Japanese than their children and grandchildren. Eun-Ai Cho, born in 1927 to first generation Korean immigrants, commented repeatedly on her father's prejudice towards Japanese immigrants. Eun's father taught himself English and Chinese and regularly read a Chinese newspaper, but "Naturally not the Japanese." When Eun was older and had moved away, she sent a letter to inform her dad of her coming wedding to a German-American. He took the news well, showing he had embraced some of his daughter's progressive views about intermarriage. ${ }^{166}$ Eun recounted, "[S]hort, fat, or whatever nationality, it was just fine, except Japanese, my dad said.” A few years later he was less accepting when Eun told him that she and her husband were adopting a child of Japanese

\footnotetext{
${ }^{165}$ Eun Sik Yang, 22.

${ }^{166}$ According to one study, only 104 Korean males married non-Koreans from 1912 to 1924, despite the low numbers of Korean females in America at that time. The significantly higher rate of intermarriage in the 1930s and 1940s, (much less the approval by some parents) indicates the rapid change in traditional Korean culture in the Korean American community. Won Moo Hurh and Kwang Chung Kim, Korean Immigrants in America: A structural Analysis of Ethnic Confinement and Adhesive Adaption (Ontario, Associated University Presses, 1984).
} 
heritage. "My father became unglued when he learned our last child, Karen was part Japanese. Again, I fixed him royally because I plopped her down on his lap and gave him a bottle to feed her. I have a picture of him looking away from her and still feeding the child." 167

Other accounts recall similar experiences. Salome Ham Ambrose, daughter to Korean immigrants, recalled her frustrations as a child with no Korean friends. "I hated Sprecklesville because there was little freedom to even play with friends. If I went to the Filipino camp to see my girl friends, I'd get spankings. My mother wouldn't let me play with the Japanese girls. She said they were our enemies. What could I do?" 168 Rachel Sung-sil Kim said, "My parents had strong-anti-Japanese sentiments. If ever we were going to date a Japanese boy we could not let my mother know. To her it was alright to date a Caucasian but not a Japanese."169 John YoungAhn Kim married a Japanese woman against the will of his parents. Kim remembered, "My father had little to say when I told him I was marrying a Japanese woman. At first my mother had to say something against me. After that she gave in. There was nothing she could have done. But many of her friends, who thought I didn't understand what they were saying, asked my mother, 'Why with our enemy.","170

\footnotetext{
${ }^{167}$ Eun-Ai Cho, “A Follower of Dr. Rhee" Passages to Paradise: Early Korean Immigrant Narratives from Hawaii, ed. Daisy Chun Rhodes (Los Angeles: Academia Koreana, Keimyang University Press, 1998), 30.

${ }^{168}$ Salome Ham Ambrose, "Yerusalem," Passages, 175-178.

${ }^{169}$ Rachael Sung-sil Kim, “What Have We Done?," Passages, 103.

${ }^{170}$ John Young-Ahn Kim, “Coming to Hawai'I,” Passages, 14.
} 
In contrast to earlier generations is Mary Paik Lee. Lee was thirty-five and living in California when the federal government relocated her Japanese neighbors to internment camps in 1941. Instead of relief or satisfaction that the older generation may have expressed about Japanese internment, Lee recounted it more solemnly. "Our neighbors asked if we would look after their farms; they told us to take anything we wanted from their homes." Lee remembered. "They were our friends, so we couldn't do that, but we said we would look after their things as much as possible." ${ }^{171}$

Accounts by children of immigrants often describe how their identity, cultural values and behavior differed from those of their parents. The children of immigrants relate far less anti-Japanese sentiment in recalling their own adult experiences. That is, they do not mention avoiding Japanese stores, forbidding their children from playing with Japanese children or scorning intermarriage between Korean and Japanese. This does not prove it did not occur. Many children of immigrants may have espoused some of the prejudice their parents held toward Japanese. ${ }^{172}$ But the absence of these recollections in younger generations suggests anti-Japanese sentiment had lessoned with time. By the 1930s, Korean immigrants had progressively integrated Japanese immigrants into their more personal relationships. Asia was a far-away and imagined place, and the Japanese that second generation Koreans knew were not the brutal oppressors their parents had told them to abhor. Mary Paik Lee, John Young-Ahn Kim and Eun-Ai Cho had all heard and read that the

\footnotetext{
${ }^{171}$ Mary Paik Lee, 94.

172 One example is the case of Soon-Young Hong, son of a sugar plantation laborer and a picture bride, who said at the beginning of World War II, "I had already been brainwashed by my parents to be anti-Japanese, so naturally, what I saw in the war made me very bitter against the Japanese." SoonYoung Hong, Passages to Paradise, 153.
} 
Japanese were enemies, but what they experienced first-hand was different. The Japanese they knew were other immigrants and not the brutal soldiers who shoved poor families from their homes and set fire to their churches. The Japanese with whom they had tangible experiences were their classmates and neighbors and people that the second generation would include as friends, spouses and children.

Seemingly, for Korean Americans who mixed with Japanese far more than the earliest Korean immigrants, the "enemy" was no longer so clearly defined.

For Korean immigrants in America, the Japanese became more and more a conceptual enemy, a narrative passed down from parent to child, and supported through newspaper articles, but seldom based on first hand experience. The concepts they held about Korea and its right to independence as well as the identity they adopted as Korean patriots, was also a concept constructed by first generation immigrants. Benedict Anderson explains that, "awareness of being embedded in secular, serial time, with all its implications of continuity, yet of 'forgetting' the experience of this continuity engender the need for a narrative." ${ }^{173}$ In other words, second generation Korean immigrants had to be told what their Korean identity entailed, that it encompassed a history and country from which they had no actual memories. ${ }^{174}$ I argue that when it came to Korea's independence and

\footnotetext{
${ }^{173}$ Benedict Anderson. Imagined Communities: Reflections of the Origins and Spread of Nationalism (New York: Verso, 2006), 205.

${ }^{174}$ Dora Yum Kim, born to first generation Korean immigrants in 1921 and who grew up in San Francisco, recalled how her parents passed on a sense of Korean identity saying, "We weren't exactly immersed in the Korean community because there were so few Koreans around us. Korean activities were limited to the Independence Movement and other church related activities once a week or so. So growing up, our parents had to drill into us that we were Korean." Soo-Young Chin. Doing What Had to Be Done: The Life Narrative of Dora Yum Kim (Philadelphia, Temple University Press, 1999), 18.
} 
conceptualization of Korea's enemy, the Japanese, it seems that second generation

Koreans in America did not have enough imagination to carry the Korean

Independence Movement through its economic and political struggles.

It was in 1937, with the Japanese invasion of China, that the Korean

Independence Movement slowly roused from its fifteen-year hibernation. On July

seventh of that year, Japanese and Chinese armies faced off at Lugou Bridge in

Beijing (known as the Marco Polo Incident). Shortly thereafter, the Japanese invaded

and occupied Shanghai, Nanjing and Northern Shanxi, using exorbitant violence and

killing thousands of innocent citizens. Japanese brutality stirred up resentments and

many Koreans in Asia and abroad saw the invasion as a precursor to war. The

Koreans knew the invasion invited Chinese retaliation and threatened Western powers

too. The Allied Powers could justify recognizing Japanese colonization of Korea, but

a colonized China would undoubtedly leave them anxious. This left Koreans hopeful,

for in the case of war they believed the Japanese would surely suffer defeat. ${ }^{175}$

Koreans in America reacted to these events by forming at least three new

patriotic clubs. The most prominent was the China Aid Society in Los Angeles

founded in 1937. Progressive nationalists established the club to help organize

\footnotetext{
${ }^{175}$ Chong-sik Lee, 264-267. The Japanese would not simply leapfrog into China when Korea, their Korea, offered a convenient rest stop between Japan and China. Of course, Korea paid a high price for Japanese expansion in China. Japanese officials hoped assimilation would inspire Koreans to discontinue their attempts at independence and, perhaps more importantly in the face of a looming world war, volunteer for the Japanese army. The Japanese, therefore, implemented fast track system to assimilate and subdue Koreans whose resentments, they accurately predicted, would certainly swell under the wartime strain. Japanese officials imposed stricter guidelines on the teaching and speaking of Korean, shut down Korean newspapers and implemented a patriotic group system throughout Korea which elaborately categorized neighborhoods into networks. The system "encouraged" groups to march to Shinto shrines (an insult to Christianity which so many Koreans had by this time adopted) to pray for Japanese victory and to show other forms of allegiance to the Japanese government. Though technically voluntary, the new system successfully assembled Korean participants because without cooperation, the networks would not receive their food rations.
} 
protests against Japanese military expansion and to fund guerilla warfare in China. They advocated cooperation with America and China and boycotted Japanese goods, picketed Japanese consulate offices and other activities meant to raise awareness within America. The China Aid Society, along with the Sino-Korean People's League in Hawaii, founded in 1938 and the Korean People's Revolutionary Party, founded in 1939, represent the emergence of increasingly confrontational practices among Korean patriots. ${ }^{176}$

Members of the China Aid Society did not share ideological and strategic opinions with the more conservative groups in America, particularly the Korean National Association. The more conservative activists distanced themselves from the progressive groups which they accused of being associated with communists. ${ }^{177}$ Therefore, their activism beginning in 1937 did not indicate a unified movement in America. Nonetheless, it was the first serious attempt to re-energize Korean patriotism and American awareness in over a decade.

A unified movement among Koreans in America was soon to follow, however. On April twentieth, 1941, representatives from nine different Korean social and political clubs gathered at the Korean National Association headquarters in Honolulu for the All-Korean Convention where they formulated a unified movement against the Japanese under the new name: The United Korean Committee.

\footnotetext{
${ }^{176}$ Choy, Koreans in America, 120, 169.

${ }^{177}$ Choy, Koreans in America, 120-121. Choy also writes that the party did not disband until 1955 and that some of its leaders were forced to leave the United States after being investigated by United States authorities, under Red Scare policies, I presume, for the party "reported extensively on North Korean affairs" in their Los Angeles based newspaper. This factionalism, which occurred in America and China where leftist groups had a stronger hold than in America, foreshadowed the democratic/communist division of post-colonized Korea.
} 
Participating clubs pledged to honor the United Korean Committee as the decisive voice concerning political and financial concerns. The Committee meant to serve as the only diplomatic agent representing the Korean community in America.

Furthermore, participants in the Committee agreed to give their unconditional support to the Korean Provisional Government in China. Attendees appointed Rhee as chairman to be supervised under the strict guidance of an elected board of directors, the majority of whom belonged to conservative political clubs like the KNA. ${ }^{178}$

Among the nine clubs to join in the United Korean Committee were at least two women's clubs, the Women's Patriotic Society and Women's Relief Society of Hawaii. Moreover, conference participants elected six Korean women to serve in various committees. Although Korean women in America had taken on leadership positions within women-exclusive patriotic groups, organizing boycotts, parades and heading successful fundraising campaigns for decades, this was the first time that Korean women filled leadership positions alongside men in a patriotic club. ${ }^{179}$ In the past, Korean men relied on women's clubs for fundraising. However, by serving with men, and not just in complimentary women's clubs, Korean women were now integrated into international political procedures.

One of the primary objectives of the United Korean Committee was to contact American government officials and other allied powers about Korean liberation and persuade them to recognize the Korean Provisional Government. Scholar Bong-youn Choy claimed that Rhee met with several government officials from whom he

\footnotetext{
${ }^{178}$ Choy, Koreans in America, 171.

${ }^{179}$ Yang, 21.
} 
received well wishes but nothing in the form of monetary or military aid. Rhee once had his hopes raised when he met with Major Wallace H. Moore from the Army intelligence service, who promised to secure aid for Korean patriots in China. It is unclear as to how much Moore was actually able to help. ${ }^{180}$ Apart from this offer, Koreans in America gathered little more than sympathetic shrugs from governmental higher-ups. Rhee and the United Korean Committee were not the only bodies petitioning for American support. In 1941, Kim Ku, president of the Korean Provisional Government, sent a letter to President Roosevelt requesting U.S. recognition of the Government. That same year, Han Kilsu, head of the SinoKorean's People's League, wrote to Roosevelt urging him to act more aggressively against Japan. The Division of Far Eastern Affairs office took no other action than to file the letter. ${ }^{181}$

In 1941, Korean patriots finally received a reply from the acting Secretary of State Joseph Grew in response to the United Korean Committee's implorations to officially recognize the Korean Provisional Government as the legal government of the Korean people. Grew issued a formal report stating, "The 'Korean Provisional Government' has never exercised administrative authority over any part of Korea, nor can it be regarded as representative of the Korean people of today. Due to

\footnotetext{
${ }^{180}$ Choy, Koreans in America, 175-176. The Korean Provisional Government seemed so encouraged by Moore's statement that they soon after declared war against Japan.

${ }^{181}$ Savage, 207, 277.
} 
geographical and other factors its following even among exiled Koreans is inevitably limited."

For Korean activists, U.S. support must have seemed like a fish they felt close to catching but which repeatedly slipped through their fingers. In February 1942, for example, William R. Langdon of the Far Eastern Division of the State Department issued an eighteen page report concerning the issue of Korean independence. He stated that while Koreans in the homeland may appear loyal to the Japanese government, their behavior was only a defensive façade. Langdon expressed sympathy for Koreans but ultimately stressed the difficulties associated with supporting Korean nationals, namely that it was too risky diplomatically. He also argued that support of the Korean Provisional Government before the United States secured victory over Japan would be preemptive and therefore unbeneficial and perhaps harmful to the Korean people and their cause. To add insult to injury, Grew claimed that independence might in fact disserve the Korean people whom he doubted could govern themselves effectively. ${ }^{183}$ Once again, the U.S. government erred on the side of diplomatic caution.

Despite the denial of assistance this eighteen page report ironically indicated progress for Koreans in America. After all, it was a formal response from the government, and was nonetheless a form of recognition. This was a significant improvement from 1919 when Syngman Rhee's letter to Woodrow did not even pass the president's desk before disappearing into the "Do Not Acknowledge" file. Of

\footnotetext{
${ }^{182}$ Choy, Koreans in America, 177.

${ }^{183}$ Savage, 209.
} 
course, the president did not formally address the Korean issue, but if U.S. policymakers did not acquiesce to Korean appeals for support, they at least began to acknowledge them.

Despite rejection, Syngman Rhee continued preaching Korea's right to liberty in the upcoming years. In 1941, several months before the attack on Pearl Harbor, Syngman Rhee published Japan Inside Out, a book that warned Americans of the impending confrontation with Japan. Rhee wrote he had been trying to warn the American government about the dangers of aggressive Japanese expansion since 1904 but encountered mostly disbelief about the situation. Japan, as Rhee hoped to prove, "is engaged in a long-term program to establish hegemony over Asia, and, eventually, to dominate the world."184

According to Rhee, the Japanese were skillful manipulators of American action and thought. He claimed that since the early 1900s, Japan spent millions of dollars disseminating positive impressions of Japan within America. Although Rhee did not clarify by what means the Japanese circulated these impressions, "The charm of the people, the beauty of the country, the silk kimonos, cherry blossoms, and the ancient culture, which 'excelled' Western civilization, were fascinating themes for newspaper and magazine articles," purposefully dispensed as an effort to "win over" influential people in America. ${ }^{185}$ By describing a cunning plan of infiltration by Japanese immigrants, Rhee utilized the language of yellow peril mania, a tactic he

\footnotetext{
${ }^{184}$ Rhee, Japan Inside Out, 199.

${ }^{185}$ Rhee, Japan Inside Out, 160.
} 
likely hoped would distinguish Koreans from Japanese immigrants to an undifferentiating white American audience.

Rhee reported that the Japanese executed a strong influence over newspapers and that the media avoided publishing anything negative about Japanese because they would be bombarded with criticisms by the Japanese and their friends. "At the same time, anything that would flatter the Japanese occupied the front page or a prominent place. Through this process," Rhee continued, "the Japanese gradually succeeded in creating a peculiar psychology in America, so that any anti-Japanese sentiment was generally tabooed, except among labor groups.",186

Rhee proved himself a contradictory character. His tactic of vilifying Japanese character and capitalizing on pre-war paranoia appear similar to tactics used by Korean leftist groups in America, groups with whom he found himself in constant disagreement. Additionally, his enmity towards the Japanese seems incongruous with the changing attitudes of younger Koreans who accepted the Japanese. It is clear that Rhee intended to jumpstart a confrontation between America and Japan as well as to distinguish Koreans from Japanese. Rhee argued that Koreans were, in their very nature, different from the Japanese and that Koreans had recognized for over forty years what Americans were just coming to recognize, that Japanese aggression was a threat the world.

America realized the threat on December seventh, 1941, when Japanese troops attacked the U.S. naval base at Pearl Harbor in Hawaii. On December eighth, the United States declared war on Japan, entering World War II. Within a matter of

\footnotetext{
${ }^{186}$ Rhee, Japan Inside Out, 161-163.
} 
weeks the federal government relocated 110,000 Japanese residents from their homes in Washington, Oregon and California to internment camps throughout the interior West. Though they were recognized legal subjects of Japan, the Justice Department spared Koreans in America by not requiring them to register as enemy aliens, exempting them from internment.

This simple measure was important for Koreans. While their Japanese neighbors left their houses, property and belongings, Koreans remained in their homes. ${ }^{187}$ Even more, it was the first time in thirty-five years that American government policy officially differentiated Korean immigrants from Japanese. ${ }^{188}$ The formal recognition by the United States was a symbolic milestone for Koreans.

From the gloomy shadows of the Pearl Harbor attack, arose the most joyful news for Korean patriots everywhere. On February eleventh, 1942, Rhee issued a letter to the Korean community in America rejoicing that America would be fighting on Korea's side against Japan. "We are no longer fighting alone. We are fighting Japan with and for the Allied Powers." Rhee reassured his fellow Korean immigrants that the prospect of America officially recognizing the Korean Provisional Government as Korea's authorized governmental body was near and that their most

\footnotetext{
${ }^{187}$ There is little reason to believe that Korean allegiance to America had any influence on sparing them from internment camps; after all, the Japanese community had also professed loyalty to America. Patricia Nelson Limerick gives the example of the Japanese American Citizen League who provided a statement praising America's "institutions, ideals and traditions" and showing gratitude for the opportunities America has bestowed on Japanese immigrants. The Legacy of Conquest: The Unbroken Past of the American West (New York: W. W. Norton and Company, Inc., 1987), 274.

${ }^{188}$ See Savage, 208.
} 
important task was to "act strictly in accordance with the spirit of unity and stability" so as to cast any doubts about the legitimacy of the Korean government. ${ }^{189}$

Near the end of World War II, the United States began to take a serious interest in Korea. Despite the efforts of leading Korean activists, this did not entail recognition of the Provisional Government, however. Instead the U.S. government considered how best to occupy Korea after it defeated Japan. The United States, Great Britain, China and the Soviet Union agreed on a four-power trusteeship, that in the days leading up to Korea's liberation, whittled to a two-power trusteeship—-the United States and Soviet Russia. ${ }^{190}$

It is unknown whether the super powers consulted Korean authorities when devising their post-Korean liberation plans. In 1942, the United Korean Committee composed a memorandum to the U.S. Office of Strategic Services discussing post war occupation of Korea. The Committee wrote: "[I]t would be the army of the United States who would reoccupy Korea. The occupation by any other army, say the Russians, would not be desirable on grounds of historic and past overtures in Korea by these people."191 Even as its stance toward Korea became more sympathetic, the

\footnotetext{
${ }^{189}$ Rhee, Washington D.C., open letter to fellow Koreans, 11, February, 1942.

${ }^{190}$ In 1945, Rhee continued to pressure the Allied Powers to support the Provisional Government, claiming that without it, the Soviet Union would likely enter Korea and set up a puppet government there (again capitalizing on American fears?). The State Department found no evidence to validate this statement, and Stalin repeatedly asserted his support for a four-power trusteeship of post World War II Korea. Nonetheless, Savage claims that Rhee's threat bothered U.S. officials, which prompted them to forego a four-power division. America briefly hoped to gain full trusteeship over Korea, but when learning that Russian troops were available and quickly advancing towards Korea after the dropping of the atomic bombs, they instead decided to split the country down the thirty-eighth parallel, a border that still continues to divide the peninsula. Savage, 220-221.

191 "United Korean Committee Memorandum" October 1942, Special Collections, East Asian Library digital archive, University of Southern California Los Angeles. http:digitallibrary.usc.edu/assetserver/controller/viewsearch/KADA-shyun06-040.
} 
United States and other international policy-making nations still managed to overlook Korean activist wishes in favor of their own governmental visions. ${ }^{192}$

Nonetheless, historian Timothy Savage claims that the American government, not unlike the Chinese government in 1937, began to see Korean immigrants in a new light- “once a minor annoyance," Koreans in America were now a valuable group to help boost military support and financial aid. ${ }^{193}$ Sparing Koreans from internment camps was not only a way of recognizing their political pleas; it also gave the U.S. government the opportunity to utilize a potentially valuable group. Koreans in America, for example, donated a significant amount of money during World War II. In 1943, Koreans in Hawaii contributed $\$ 26,265$ to the U.S. government for "victory funds." This suggests that by World War II, Korean immigrants supported the American cause as a whole and not just the liberation of Korea. One report indicated that Koreans in America spent an estimated \$239,130 in defense bonds from 1942 to 1943. ${ }^{194}$ It is noteworthy that Koreans donated so much to U.S. defense funding. After all, donations were not spent on matters of Korean Independence and Koreans certainly could have saved their donations for the Korean Provisional Government or funds headed strictly for Korea. This generosity was due in part because their

\footnotetext{
${ }^{192}$ Of course, the United Korean Committee did not speak for the whole international Korean community, including the sizeable group in China. It is possible that in dividing Korea into two trusteeships, America and Russia were being sensitive to the wants of a diverse population of Koreans, that is, as sensitive as they could be without much consulting the Koreans.

${ }^{193}$ Savage, 207.

${ }^{194}$ Kim and Patterson, 46.
} 
economic situation improved and because, in part, their patriotism had been

recharged. ${ }^{195}$

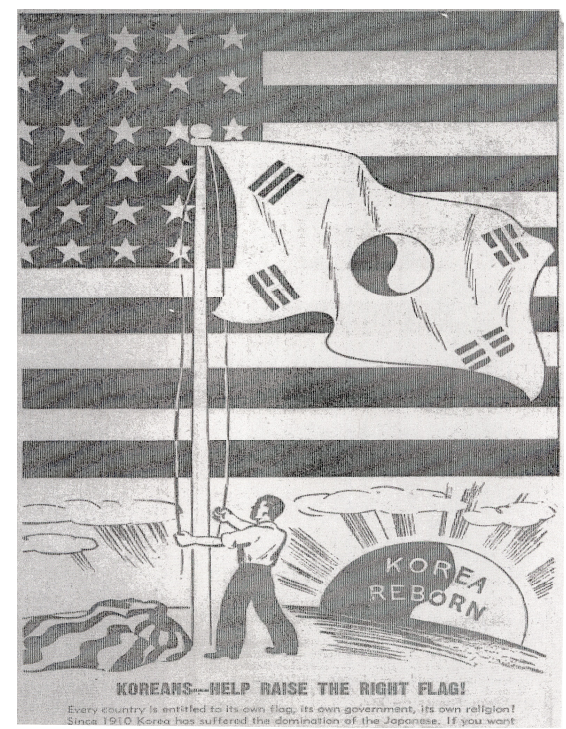

Figure 3: Reprinted with the permission of the Korean American Digital Archive, University of Southern California

The above image advertised a fund drive in Honolulu during World War II.

The text underneath stated:

Every country is entitled to its own flag, its own government, its own religion! Since 1910 Korea has suffered from the domination of the Japanese. If you want to help lower the flag of the hated conqueror and raise that of old Korea-help put over the American-Korean Victory Fund Drive. Every cent raised during this drive (ending August $29^{\text {th }}$ ) will be sent directly to President Roosevelt to use AS HE SEE FITS! 196

\footnotetext{
${ }^{195}$ Some Koreans recalled living comfortably for the first time during World War II. Mary Paik Lee remembered, "Since most of the vegetable farmers had been Japanese, the wholesale business in Los Angeles was deserted. That meant good prices for the remaining farmers, us included. We had several years of good crops and higher market prices, which made up for all these years of nothing in the past." 96. Rachel Sung-Sil Kim recalled, "Then World War II broke out. For the first time in their lives, my parents were paid decent wages...My father was so proud when he came home from work with his first paycheck in hand." "What Have We Done," 102-103.

196 Special Collections, East Asian Library digital archive, University of Southern California Los Angeles. Exact date and source unknown. http://digitallibrary.usc.edu/search/controller/view/kadam2080.html
} 
The text indicates a trust in the American government to dependably handle Korea's cause, perhaps even better than the Korean Provisional Government. The image, with the backdrop of the American flag and the symbolic rising sun, further suggests that Korean Americans understood, or at least portrayed, America's declaration of war against Japan as the beginning of a united battle, that America was taking up Korea's cause for freedom to restore its rightful place among independent nations.

Korean participation in the U.S. military further indicates this concept. Shortly after the attack on Pearl Harbor, Colonel Hughes, commander of the California National Guard, requested the leader of the United Korean Committee to assemble a Korean military unit. Koreans reacted eagerly. Within a few weeks, fifty Koreans registered for military training ${ }^{197}$ The California National Guard created a specific branch, the Tiger Brigade, designated for Korean volunteers. Military service attracted both young and old Koreans, U.S. citizens and non-U.S. citizens. Older Korean immigrant men, many over sixty years of age, constituted most of the group. About 140 Korean volunteers received military training under the supervision of U.S. army officials. The participants practiced their military drills every Saturday and Sunday afternoon to ready a defense of California in case of a foreign attack. ${ }^{198}$ Older Korean immigrants who could not serve in the military volunteered as National

\footnotetext{
${ }^{197}$ Kim and Patterson, 45.

${ }^{198}$ Bong-youn Choy, "The History of Early Koreans in America" in Koreans in North America: New Perspectives, ed Seoung Hyong Lee and Tae-Hwan Kwak (Kyungnam University Press, 1988), 31-32.
} 
Guardsmen as emergency fire wardens or in military facilities. Elderly Korean women often volunteered at the Red Cross and organized to sell war bonds." There were several ways in which Korean women could work for Korea's freedom and support American war efforts. Inez Pak-Soon Kong, who was in her early twenties when the war broke out, worked directly under Rhee in Washington, running errands, presenting speeches and writing articles about Japanese atrocities, which she claimed were published nationwide. ${ }^{200}$ Kong, and women like her, could utilize their college education, English fluency and less-restrained social roles to work for Korea's liberty in ways their mothers and grandmothers could not. Korean American women were also interested in serving in the military. Kong recalled how, "When I went to Washington I immediately applied to go and help the Flying Tigers because I had friends there. I thought, 'I'll go to China because I' $m$ interested in the Korean situation."' The Flying Tigers recruited nine women who were specifically not Japanese American to act as translators. Kong felt very passionate about this cause, saying, "I wanted to be one of those nine selected." Kong was eventually accepted, but turned the position down because by that time she had fallen in love. However, she knew other Korean women who served for the Flying Tigers. ${ }^{201}$ Their service in the military suggests that Korean immigrants and their children had a

\footnotetext{
${ }^{199}$ Choy, "The History of Early Korean Immigrants," 31.

${ }^{200}$ Inez Pak-Soon Kong, "Walking a Hundred Miles," Passages, 66. Kong claimed that Rhee's opponents were also working in Washington. Rhee admonished her when she began associating with them, calling them traitors and communists. Although Rhee requested her personally to come work for him in Washington, she eventually "got on his blacklist" and was banned from Rhee's office.

${ }^{201}$ Inez Pak-Soon Kong Passages, 65-66.
} 
strong allegiance to America. In addition, the fact that very few Koreans returned to Korea after Korean liberation supports this assertion. ${ }^{202}$

Although Koreans served in the U.S. military and national policy finally differentiated Koreans from Japanese, White Americans did not instantly follow suit. Rhee may have claimed that their "American friends" were finally fighting on their side, but most white Americans were likely unaware of this. Wartime brought a rise in animosity towards Japanese immigrants. White Americans, who were often nondiscriminatory in their discrimination practices, targeted Koreans (and Chinese) as much as they targeted the Japanese. The United States government may have spared them from interment camps, but the wider American public did not spare them from anti-Japanese sentiment. ${ }^{203}$ America's entry into World War II was a crowning moment for Korean patriots, but it also made life in America more difficult for them. Mary Paik Lee's memoir reveals the difficulty of life in California during the 1930s and 1940s. Not only did she watch as her Japanese friends unhappily left their homes for internment camp, she also wrote of the horrible treatment she and other Asian

\footnotetext{
${ }^{202}$ Wayne Patterson says that only one in six Korean immigrants ever returned to Korea. At least half of the Japanese and Chinese immigrants eventually returned to their homelands. The Korean Frontier in America: Immigration to Hawaii 196-1910 (Honolulu: University of Hawaii Press), 106.

${ }^{203}$ The attack on Pearl Harbor worsened the situation for Japanese immigrants in America who endured discrimination and persecution since they first arrived in large numbers in the late nineteenth century. Anti-Japanese sentiments only increased in the years leading up to America's entry in to World War II. Indeed some Americans characterized Japanese as intelligent, cooperative and civilized. But for anti-Asian activists, these were not positive traits. They were instead clear evidence of the cunning, deceitful nature of the Japanese and evidence of their underground ploy to infiltrate America. American authorities became concerned with the activities of Japanese secret societies in America, such as the "ultra-nationalistic" Black Dragon Society, whose leader was arrested shortly after the attack and who committed suicide while being held in a temporary prison compound. Incidences like this raised suspicions while the media perpetuated myths about Japanese imperialism and their incessant desire to take over America and the world. The attack on Pearl Harbor only exasperated many Americans' fears of the "Japanese menace." See Limerick, 271 and Bong Choy, Koreans in America, 173.
} 
Americans endured due to heightened anti-Japanese hostilities. Lee, and her husband worked as vegetable farmers in South Whittier, California at the time of the Pearl Harbor attack. Lee recalled that on the day of the attack, she stopped at a store on her way back from taking the field workers home. Having worked all day, she was not yet aware of the news. She left her son in the truck to quickly go into the store. Upon entering she encountered a roomful of hateful expressions pointed at her. One customer said, "There's one of them damned Japs now. What's she doing here?" The grocery store owner defended Lee, but that was not the end of it. When Lee returned to her truck she found three teenaged boys threatening to strike her one-year-old son. In other incidences customers of Lee "slapped and cursed" her other son, Allan, at their roadside vegetable stand. Of course, Lee was dismayed. She recounted:

I don't understand how women with young children at home could hit a child for something that had happened somewhere else. They just assumed that all Orientals were Japanese; they didn't even bother to find out before committing violence. Even after all the Japanese were taken away to concentration camps, other Orientals were subjected to all kinds of violence. They were afraid to go out at night; many were beaten even during the day. Their cars were wrecked. The tires were slashed, the radios and batteries removed. Some friends driving on highways were stopped and their cars were overturned. It was a bad time for all of us. 204

Some Koreans took aims to differentiate themselves from the Japanese. Eun Ai-

Cho related:

When World War II began my father described it as eventual liberation for Korea. The Japanese enemy was being recognized as the enemy. My father said, "See, they are true to form. Now the sleeping giant is aroused. We will be free." He and his friends wore buttons upon with were emblazoned, "I am a Korean" so that they could be distinguished from the Japanese. ${ }^{205}$

\footnotetext{
${ }^{204}$ Mary Paik Lee, Quiet Odyssey, 95.

${ }^{205}$ Eun-Ai Cho, “A Follower of Dr. Rhee," in Passages, 24.
} 
Cho's father's reaction reveals both excitement for Korea's liberation as well as fear of the likely backlash of anti-Japanese sentiment. In this way, Koreans in America had not escaped the repercussions of Japanese imperialism after all.

Koreans probably hoped that military service would prove their Americanization in the same way that participants of the Korean Congress most hoped their overt American patriotism would resonate with a broader U.S. audience. In contrast, Nam Young Chung wrote about racial discrimination and serving for the U.S. Army:

I was a captain during the United States occupation of Korea at the end of World War II. I met my wife there in 1946 and married her that year. At that time, because of the Exclusion Act, my wife was prohibited from coming to the United States. Facing the Exclusion Act was nothing new to us. Like other children of immigrants growing up in Hawaii, we always had to live under the yoke of racial discrimination, discrimination in living conditions, wages, treatment in existing social structures. We hope that it would all be changed. ${ }^{206}$

Memoir reveals something that international political histories, domestic legislative policies or Korean patriotic club financial records cannot. They provide stories of wartime experiences, illustrate the fear and sadness Koreans endured on account of white American animosity towards Asians, and the hope they felt over Korea's eventual liberation, experiences that compelled them to further entrench themselves in both their Korean and American identities simultaneously.

On August fifteenth, 1945, Japan surrendered to the Allied powers ushering in the close of World War II. For Koreans, this news included the Korean liberation from Japan, news that Koreans in America also received joyfully. Soon-Young Hong remembered, "On the day of the Japanese surrender, my parents just bawled their

\footnotetext{
${ }^{206}$ Nam-Young Chung in Passages, 37.
} 
heads off, so happy the Japanese had lost. It was so emotional. I shall never forget their emotions." 207 After forty years, the Korean Independence Movement came to an end.

This period from America's entry into World War II to Japan's surrender was a symbolic triumph for Koreans in America. Their exemption from Executive Order 9066, as well as the fact that the U.S. government, after years of pleas, confronted Japanese aggressors, finally gave them a sense of recognition in America. Korean women in America, more so than in any other time in the Korean Independence Movement, worked alongside Korean men in leadership positions. Younger Koreans, those who grew up in America retained their parents' sense of patriotism towards Korea but did not manage to sustain the K.I.M. through the Depression Era. They revitalized their passion for Korean independence during World War II, except, unlike their parents, they fought for Korea's freedom by serving in the American military. This form of activism indicated a strong allegiance to America.

Koreans' social standing among America's white population did not reflect this shift in identity nor these significant symbolic triumphs that Koreans celebrated. Korea's liberation from Japan did not ease Koreans' lives in America, but in fact made it more difficult as they suffered greater persecution. The closing of World War II and the end of the Korean Independence Movement did little to change the lives of Koreans in America. The routine of participating in the Korean Independence Movement from abroad for decades did shape the Korean American

\footnotetext{
${ }^{207}$ Soon-Young Hong, “An Activist in Seoul," Passages to Paradise: Early Korean Immigrant Narratives from Hawaii, ed. Daisy Chun Rhodes (Los Angeles: Academia Koreana, Keimyang University Press, 1998), 153.
} 
experience, however, because it focused their attention on their Korean heritage while serving as a platform for their Americanization process. The closing of the Korean Independence Movement, then, marks the closing of a very important period for the earliest Korean immigrants in America, one from Korean immigrants in America to Korean Americans. 


\section{Conclusion}

Identity is a precarious construction. The labels with which individuals identify, whether ethnic, national or gender-based, are often vague, their definitions ever evolving and dissolving. And yet, despite their ambiguous, even imaginary construction, individuals and groups will at times closely guard their identity. The early Korean immigrants in America were no exception. Upon moving to Hawaii in the early nineteenth century, Koreans found themselves in a world in which all their previous known gender, political and social roles had changed considerably. In response, Korean immigrants ardently defended their unique national identity, defining it both on what they were not (Japanese) as on what they were (ethnic Koreans, distinct in history, language and culture). Although their identity constructs changed throughout the years, they dedicated much energy defining and defending what it meant to be Korean in America.

Koreans in America used the Korean Independence Movement to build community, construct an identity and acculturate. Although a number of scholars have written about the Korean Independence Movement from a political perspective, this study seeks to investigate the social effects of the Korean Independence Movement on the population that sustained it through four decades, the Korean immigrants in America. By using memoir, speeches and interviews, it examines how Korean Americans understood their own history. 
The Korean American experience is not an anomaly among immigrants in America. On Hawaiian plantations they endured low wages, poor living conditions and discrimination just as their Japanese, Chinese and Portuguese counterparts. Their story however, is an important component to the Asian story in American history, one that has prompted new questions about race and led to new discriminatory legislative policies within the United States-a history that is distinct for its connections the American West. In California, Koreans faced the same restrictions on land ownership and limited potential for upward mobility as other Asian immigrants. Like the Japanese and Chinese, Koreans created new communities when they left their old lives behind. What was unique to Korean immigrants was their strong political ties to their independence movement. This movement influenced how they related to their homeland, their host country and to each other. In other words, it directly shaped their Americanization process.

The most significant wave of immigration in the first half of the twentieth century took place from 1903 to 1905 . The earliest Korean immigrants built a sense of community based on Christianity and nationalism, two relatively new concepts and both adopted from the Western world. Most Koreans believed that Korea-a country with its own culture, language and customs, validated by a long history of political autonomy—deserved its sovereignty. The 1905 infiltration of Japanese officials into Korea's political infrastructure threatened Korea's national identity and they were ready to defend it thus commencing the Korean Independence Movement.

Primary and secondary reveal that from its origin, the Korean community in America developed characteristics that distinguished it from Koreans in the 
homeland. In the United States and Hawaii, the Korean population was a heterogeneous by Korea's standards, with a mixture of people of diverse dialects, regional origins and social statuses. In America, the Korean population included a higher percentage of Christian Koreans than any place in Korea. Furthermore, America provided a more liberal and progressive setting for Korean women where they were required, but also allowed, to work outside the home. In America Korean immigrant women had greater opportunity to broaden their public roles through church and political activism.

The Korean Independence Movement was a source of commonality for Korean immigrants who no longer had the support of familiar kinship networks. Membership in patriotic clubs provided individuals with a common cause and a common enemy. It also gave them an outlet to perform their unique ethnic identity. The Korean Independence was a vital component in the construction of the early Korean immigrant community.

The Korean Independence Movement only heightened through the years. The most intense period of activism occurred from 1919 to 1921 . Korean patriots staged the March First Movement in Korea, a peaceful protest against Japanese colonialism with American and European audiences in mind. The Japanese violently repressed the peaceful dissenter, leaving thousands dead. Aside from a few heartfelt sympathies, Koreans received little response from the Western World. Their most ardent supporters were Korean activists in America who loyally demonstrated and petitioned U.S. officials for recognition. 
Yet Korean immigrant activism took a new form by 1919. In that year, Korean activists discussed their cause for independence at the Korean Congress in Philadelphia. They appealed to American politicians declaring Korea's right to independence and America's obligation to protect it. But they also expressed patriotism to America in an effort to display their acculturation and prove that Korean activism did not threaten their loyalty to the United States. By 1919, Koreans in America had no solid notions of home: they were aliens within their host country and Japanese-colonized Korea was no longer the home they knew. Their American patriotism and acculturation indicates the need for place among Korean immigrants and their desire to build connections to the country in which they would indefinitely reside. The congress attested to changes in women's roles as well. Nodie Dora Kim spoke about the expanded gender roles of Korean immigrant women, claiming that women had progressed by receiving educations and heading successful genderspecific clubs.

In the two decades between the 1919 March First Movement and America's entry into World War II, the Korean Independence Movement experienced a lull. The Depression depleted Koreans of money and patriotic zeal. However, this respite in Korean activism was due, in part, to the further acculturation of younger and second generation Koreans who did not relate the Korean Independence Movement as the earliest Korean immigrants. They never knew an independent Korea nor did they personally know the people for whom they were donating their time and money. Furthermore, they could not conceive of the Japanese as the enemy in the same way 
as their parents did. They simply did not have the same emotional pull to sustain the Korean Independence Movement as the earlier Korean immigrants.

This changed during World War II when Korean immigrants, both young and old, demonstrated their support for Korea by directly supporting the United States. The last active phase of the Korean Independence Movement lasted from 1941 to 1945. In 1941, the United States declared war on Japan-a dream come true for Korean patriots who knew that Korean independence required a governmental super power to defeat Japan. Furthermore, for the first time, American policy-makers differentiated Koreans from Japanese concerning legislative policy. While the U.S. federal government relocated Japanese immigrants and citizens to internment camps, it spared Korean immigrants, instead utilizing them to support America at war. In addition to donating large amounts of money to U.S. war funds, Koreans, including Korean women, served in the U.S. military in large numbers, demonstrating a strong loyalty to America. Syngman Rhee and other Korean immigrants expressed elation that the U.S. government was finally working in conjunction with Koreans to defeat Japan. By the 1940s, Koreans immigrants, especially second generation Koreans, fought for Korea as Americans, and not simply as Koreans in America.

The Korean Independence Movement was the common thread that connected the earliest Korean immigrants with the younger generations. Korean immigrant activism was as much a reflection of their needs and wants in America as it was a call for the liberation of Korea. The Korean Independence Movement was not just an important part of their lives, it was an important part of their Americanization 
process, one that evolved with their identity from Korean immigrant to Korean

American.

$* * *$

August fifteenth, 1945 marked the official date of Korean liberation from Japan. Of

course, Korea's liberty did not signify the return to a post-colonized Korea. To be

sure, Korean activists, as well as Russia, America and other leading nations, had

different opinions concerning how a liberated Korea should look. The ten years

following Korean liberation saw policies that separated North and South Korea. The

North came under the leadership of the formerly China-based Korean nationalist, Kim

il-sung, and the South under Syngman Rhee who served as Korea's first president

from 1948 to1960.

Shortly after the closing of World War II, the Korean immigrant community

in America dramatically transformed with the arrival of thousands of military brides,

children of servicemen and adoptees. For the first time, a large population of Koreans

entered America who did not share memories of the early Korean immigrant

experience either directly or through their parents. Nor did they take part in

constructing a Korean community on overseas activism. ${ }^{208}$ The closing of the Korean

\footnotetext{
${ }^{208}$ Bong Choy had this to say about the changes in Korean community after 1953. "The occupational pattern in America today is drastically different from that of the early immigrants. The early immigrants did monotonous, manual work, mostly in agriculture, mining, and railroad construction. The new immigrants' occupations are heterogeneous; and many are in professional fields, and many are engaged in business. The nature of the Korean community has also changed, from being countrycentered to being city-centered. The purposes of community organizations are also markedly different, having changed from a support of national independence to the protection of welfare of fellow countrymen...Early residents thought of themselves as temporary sojourners who would return to their homeland when they had enough money or the political situation permitted their return. The new immigrants are here to stay and to start a new life for themselves and their children...Another change has taken place. Between 1959 and 1971, an overwhelming majority of Korean immigrants were female." Koreans in America (Chicago: Nelson Hall, 1979), 217.
} 
Independence Movement marks the closing of a chapter in Korean immigrant history. The Korean community in America, not unlike Korea itself, was no longer a homogeneous, tightly contained population. This makes the words of early Korean immigrants all the more valuable and their stories all the more compelling. 


\section{Works Consulted}

\section{Primary Sources}

\section{Published Works}

Cha, Kyung Soo. Pumpkin Flower and Patriotism. Translated by Hyun H. Kim. Los Angeles, Korean American Education Research Center. 1991.

Chai, Alice Y. “'Mrs., K': Oral History of a Korean Picture Bride” Women's Studies Newsletter, 7, no 4 (Fall, 1979): 11.

Charr, Easurk Emsen. The Golden Mountain: The Autobiography of a Korean immigrant, 1895-1960. Urbana, IL: University of Illinois Press, 1996.

Chin, Soo-Young. Doing What Had to be Done. Philadelphia: Temple University Press, 1999.

Cuddy, Susan. "A Conversation With Susan Cuddy. The Eldest Daughter of Korean Independence Leader Ahn Ch'ang-Ho" (interview) Occasional Papers. 4 (1998-1999): 1-62.

Hyun, Peter. In the New World: The Making of a Korean American. Honolulu: University of Hawaii Press. 1995.

Kang, Connie K. Home Was the Land of the Morning Calm: A Saga of a KoreanAmerican Family. Reading, Mass.: Addsion-Wesley, 1995.

Lee, Mary Paik. Quiet Odyssey: A Pioneer Korean Woman in America. Edited by Sucheng Chan. Seattle: University of Washington Press, 1990.

Rhee, Syngman. Japan Inside Out. New York: Fleming H. Revell Company. 1941.

Rhodes, Daisy Chun. Passages to Paradise: Early Korean Immigrant Narratives from Hawai i. Los Angeles: Academia Koreana Keimyung University Press. 1998.

Sunoo, Sonia Shinn. Korean Kaleidoscope: Oral Histories, Volume One, Early 
Korean Pioneers in USA: 1903-1905. Korean Oral History Project Series No. I Sierra Mission Area, United Presbyterian Church, USA. 1982.

\section{Newspaper/Written Accounts/Speeches/Documents}

Chung, Henry. "Far Eastern Questions" New York Times. June 1, 1919. 34.

"1910 Treaty of Annexation: Annexation of Korea by Japan" August 22, 1910, USCUCLA Joint East Asian Studies Center. www.international.ucla.edu/eas/documents/kore1910.htm.

First Korean Congress, minutes, April 14-16, 1919, Philadelphia, Committee Print www.archive.org/details/cu3192407456077. (accessed 1/18/2010).

"Korea Makes Plea for Independence: Nation asks United States for Recognition and Aid." May 5, 1921, Washington D.C. Newspaper unknown. East Asian Library, Archival Research Center, University of Southern California. From the private collections of David Hyun.

http://digarc.usc.edu/search/controller/view/kada-m295.html. (accessed $2 / 5 / 09)$.

Wilson, Woodrow "Fourteen Points Speech" Speech, January 8, 1918, Washington D.C. www.firstworldwar.com/source/fourteenpoints.html (accessed 4/21/2010).

Soon Hyun. "The Independence Movement in Korea” East Asian Library, Archival Research Center, University of Southern California, Los Angeles, CA. http://digarc.usc.edu/search/controller/view/kada-m732.html (accessed February5, 2009).

"Syngman Rhee open letters," February 11, 1942, East Asian Library, Archival ResearchCenter, University of Southern California, Los Angeles, CA box 14/Item 15.

http://digarc.usc.edu:8089/cispubsearch/jpgview.jsp?object_name=kadam7931\&ORN (accessed February 5, 2007).

"United Korean Committee Memorandum," October, 1942, East Asian Library, ArchivalResearch Center, University of Southern California, Los Angeles, CA. http:digitallibrary.usc.edu/assetserver/controller/viewsearch/KADAshyun06-040 (accessed June 11, 2010).

Yun, Pyong-Suk. “ The Independence Movement Activities of Dosan Ahn Chang-ho in America." Speech given at an international academic conference called 
“Dosan: Korean-American" on February 3 ${ }^{\text {rd }}, 1994$ in Los Angeles. Translated by Dr. Tschung Sun Kim. http://www.gkn-la.net/dosan_resources/dosan2.htm. (accessed February 12th, 2007).

"Korea Makes Plea for Independence: Nation asks United States for Recognition and Aid." May 5, 1921, Washington D.C. Newspaper unknown. East Asian Library, Archival Research Center, University of Southern California. From the private collections of David Hyun.

http://digarc.usc.edu/search/controller/view/kada-m295.html. (accessed February 5, 2009).

\section{Photographs/illustrations}

Figure 1

"[Protestors Against Japan Trade]” Photograph. n.d. From University of Southern California: Korean American Archive Photograph Set.

http://digitallibrary.usc.edu/search/controller/view/kada-m13896.html Record ID: kada-m13896. (accessed November 11, 2006).

Figure 2

"[Korean Independence Parade in Dinuba]" Photograph. Dinuba, CA. c1920. From University of Southern California: Korean American Archive Photograph Set. Record ID: kada-m14232. http://digitallibrary.usc.edu/search/controller/view/kadam14232.html (accessed November, 17, 2006).

Figure 3

Hyun, Soon, creator. "[Koreans Help Raise the Right Flag!, Ad for the AmericanKorean Victory Fund Drive, Honolulu]" Illustration. Honolulu, HI. From University of Southern California: Korean American Archive Photograph Set. Record ID: kadam2080. http://digitallibrary.usc.edu/search/controller/view/kada-m2080.html (accessed February 16, 2007).

\section{Secondary Sources}

Anderson, Benedict. Imagined Communities: Reflections of the Origins and Spread of Nationalism. New York: Verso. 2006. 
. "Exodus" Critical Inquiry 20, no 2: 314-327.

AsianInfo.org. "March $1^{\text {st }}$ Independence Struggle"

http://www.asianinfo.org/asianinfo/korea/history/march_1st_independence_ struggle.htm (accessed 28 March, 2010).

Barkan, Elliot Robert. From All Points: America's Immigrant West, 1870's-1952. Indianapolis: Indiana University Press. 2007

Chai, Alice Yun. "Women's History in Public: 'Picture Brides' of Hawaii” Women's Studies Quarterly. 16. No. 1/2. (Spring/Summer 1988): 10-13.

Chang, Roberta W.S. The Koreans in Hawaii: A Pictorial History 1903-2003. Honolulu:University of Hawaii Press. 2003.

Choy, Bong-youn. Koreans in America. Chicago: Nelson-Hall, 1979.

"The History of Early Koreans in America" in Koreans in North America: New Perspectives, ed Seoung Hyong Lee and Tae-Hwan Kwak (Kyungnam University Press, 1988).

Clifford, James. “Diasporas” Cultural Anthropology 9, no 3: 302-338 1994.

Fan, Carol C., "Asian Women in Hawai'i: Migrations, Family, Work, Identity" NWSA Journal 8 no.1 (Spring, 1996): 70-84.

Hurh, Won Moo. The Korean Americans. Westport Connecticut: Greenwood Press. 1998.

, Won Moo and Kwang Chung Kim Korean Immigrants in America: A structural Analysis of Ethnic Confinement and Adhesive Adaption (Ontario, Associated University Presses, 1984).

Houchins, Lee and Chang-su Houchins. "The Korean Experience in America, 19031924." The Pacific Historical Review, 43, no 4 (Nov., 1974): 548-575.

Kibria, Nazli. Becoming Asian American: Second Generation Chinese and Korean American Identities. Baltimore: The Johns Hopkins University Press. 2002.

Kim, Andrew Eungi "Political Insecurity, Social Chaos, religious void and the Rise of Protestantism in late nineteenth century Korea." Social History 26, no 3 (Oct., 2001): 267-281.

Kim, Hyung-chan and Wayne Patterson. The Koreans in Hawaii 1882-1974: A 
Chronology \& Fact Book. New York: Oceana Publications. 1974.

Kim, Richard S. "Diasporic Politics and the Globalizing of America: Korean Immigrant Nationalism and the 1919 Philadelphia Korean Congress" in Asian Diasporas: New Formations New Conceptions ed. Rhacel S. Parrenas and Lok C. D. Siu.Stanford University Press, 2007.

Lee, Chong-sik. The Politics of Korean Nationalism. Berkeley: University of California Press. 1963.

Limerick, Patricia Nelson. The Legacy of Conquest: The Unbroken Past of the American West. New York: W.W. Norton and Company, Inc. 1987.

Manela, Erez. The Wilsonian Moment: Self-Determination and the International Origins of Anticolonial Nationalism. Oxford: University Press. 2007.

Murray, Alice Yang. "Ilse Women and the Early Korean American Community: Redefining Origins of Feminist Empowerment" in Unequal Sisters: a Multicultural Reader in U.S Women's History. ed. Vicki Ruiz and Ellen Carol Dubois, 205-213. New York: Rutledge. 2000.

Nugent, Walter. Into the West: The Story of its People. New York: Vintage Books, 2001.

Oh In-Cheol. Study on Korean Immigration and Independence Movements in HawaiiRelating to Korean Churches and Picture Brides-1903-2003. Cholla, Namdo, South Korea: Sung Moon, 2005.

Patterson, Wayne. The Korean Frontier in America: Immigration to Hawaii 18961910. Honolulu, University of Hawai'i Press. 1988. . The Ilse: First Generation Korean Immigrants in Hawai'i 1903-1973. Honolulu: University of Hawai'i Press. 2000.

Savage, Timothy L. "The American Response to the Korean Independence Movement, 1910-1945.” Korean Studies 20 (1996): 189-231.

Takaki, Ronald. Strangers From a Different Shore: A History of Asian Americans. New York: Penguin Books. 1989.

Wolf, Eric R. Europe and the People Without History. Berkeley: University of California Press. 1982.

Yang, Eun-Sik. "Korean Women of America: From Subordination to Partnership 
1903-1930.” Amerasia Journal 11, no. 2 (1984): 1-28.

Yow, Valerie Raleigh. Recording Oral History: A Practical Guide for Social Scientists. Thousand Oaks: Sage Publications. 1994. 